ANTONIO GERALDO DE ABREU FILHO

\title{
UM ESTUDO SOBRE AS MOTIVAÇÕES INCONSCIENTES PRESENTES NA ESCOLHA PROFISSIONAL DO ESTUDANTE DE PSICOLOGIA
}


Ficha Catalográfica preparada pelo Serviço de Biblioteca e Documentação do Instituto de Psicologia da USP

\section{Abreu Filho, A.G.}

Um estudo sobre as motivações inconscientes presentes na escolha profissional do estudante de psicologia / Antonio Geraldo de Abreu Filho. - São Paulo: s.n., 2005. - p.122.

Dissertação (mestrado) - Instituto de Psicologia da Universidade de São Paulo. Departamento de Psicologia Clínica.

Orientadora: Isabel Cristina Gomes.

1. Motivação inconsciente 2. Formação do psicólogo 3. Psicologia 4. Escolha profissional 5. Análise de conteúdo 6. Klein, Melanie, 1882-1960 I. Título. 


\section{UM ESTUDO SOBRE AS MOTIVAÇÕES \\ INCONSCIENTES PRESENTES NA ESCOLHA \\ PROFISSIONAL DO ESTUDANTE DE PSICOLOGIA}

Dissertação apresentada ao Instituto de Psicologia da Universidade de São Paulo, como parte dos requisitos para obtenção do título de Mestre em Psicologia.

Área de Concentração: Psicologia Clínica

Orientador: Prof ${ }^{a}$. Dra ${ }^{a}$. Isabel Cristina Gomes

São Paulo

2005 


\section{UM ESTUDO SOBRE AS MOTIVAÇÕES INCONSCIENTES PRESENTES NA ESCOLHA PROFISSIONAL DO ESTUDANTE DE PSICOLOGIA}

Candidato: Antonio Geraldo De Abreu Filho

Orientador: $\operatorname{Prof}^{\mathrm{a}}$. Dr ${ }^{\mathrm{a}}$. Isabel Cristina Gomes

Dissertação apresentada ao Instituto de Psicologia da Universidade de São Paulo, como parte dos requisitos para obtenção do título de Mestre em Psicologia.

COMISSÃO JULGADORA:

Defesa - 2005 


\section{AGRADECIMENTOS}

Aos meus pais (in memorian) por terem me dado a vida.

A minha esposa Berenice pelo companheirismo, carinho e valioso apoio que recebi durante esta pesquisa.

Ao meu filho Otavio pelas conversas que compartilhamos.

A todos os alunos que de maneira tão gentil e colaboradora participaram da minha pesquisa.

A minha orientadora Prof ${ }^{a}$. Dr ${ }^{a}$. Isabel Cristina Gomes pela orientação valiosa sem a qual este trabalho não teria sido possível.

Ao meu analista Vicente Silvio Nogueira pelo apoio e acolhimento.

A minha amiga Ana Luiza de Figueiredo Steiner pelo incentivo e colaboração.

A Prof ${ }^{a}$. Nivia Marcello pela colaboração nas indicações de textos na língua inglesa.

A Psicóloga Olinda Rodrigues Sampaio pelas inestimáveis orientações no início de minha prática clínica.

Ao Dr. Pérsio Osório Nogueira pela colaboração no desenvolvimento de meu olhar e escuta analíticos nos grupos de estudo e supervisão.

A Prof ${ }^{a}$. Livre Docente Leila Cury Tardivo por ter me recebido de braços abertos em minha jornada.

As colegas do APOIAR Laboratório de Saúde Mental e Psicologia Clínica Social do Instituto de Psicologia da Universidade de São Paulo pelo convívio amigo.

A todas as demais pessoas que indiretamente contribuíram para a realização desta pesquisa. 


\section{RESUMO}

Abreu Filho, A.G. Um estudo sobre as motivações inconscientes presentes na escolha profissional do estudante de Psicologia. São Paulo, 2005. Dissertação (Mestrado) Instituto de Psicologia. Universidade de São Paulo.

Este trabalho tem por objetivo verificar as motivações inconscientes presentes na escolha da profissão de psicólogo dos alunos do primeiro e segundo anos de Psicologia, procurando compreender a relação entre conteúdos latente, inconsciente, e manifesto, consciente, desta escolha, com base nos pressupostos da teoria de Melanie Klein.

Realizamos esta pesquisa utilizando dois instrumentos de investigação: a Prancha 1 do TAT, tendo por objetivo entender os conteúdos das respostas a nível inconsciente, através do mecanismo de projeção, e a utilização da Entrevista Semidirigida, objetivando que o aluno pudesse agir de modo mais natural, nos propiciando a observação de sua postura, reações e compreender os conteúdos das respostas a nível consciente.

Constatamos que os alunos tiveram percepções variadas com relação ao estímulo da Prancha 1 do TAT e várias foram as combinações das reparações apresentadas a níveis inconsciente e consciente.

Baseado nas reparações sugeridas por Bohoslavsky, inserimos dois outros tipos de reparação: autêntica/maníaca e maníaca/autêntica, mediante constatação clínica, devido a dinâmica do funcionamento mental apresentada, onde nos detivemos para isso aos elementos citados nas estórias, bem como no contexto em que as mesmas se deram, como o relato foi feito e no tipo de solução apresentada.

Verificamos através das análises das respostas, que nem sempre o que foi mostrado a nível consciente pela escolha da profissão de psicólogo, coincidiu com o nível inconsciente, revelando a importância de se levar em consideração a questão do conteúdo inconsciente presente nesta escolha.

Palavras-chaves: Motivação inconsciente. Formação do psicólogo. Psicologia. Escolha profissional. Análise do conteúdo. Klein, Melanie, 1882-1960. 


\begin{abstract}
Abreu Filho, A. G. A study on the existing unconscious motivations in the professional choice of Psychology undergraduate students. São Paulo, 2005. Dissertation (Master's). Instituto de Psicologia. Universidade de São Paulo.
\end{abstract}

This dissertation aims at studying the existing unconscious motivations in the professional choice of a psychology career of first and second year undergraduate students, trying to understand the relation between latent, unconsciousness and manifest, consciousness content of this choice from the theoretical framework of Melanie Klein.

The research was carried out through two investigation tools: Picture 1 of TAT (Thematic Apperception Test), with the objective of comprehending the content of the answers at an unconscious level, through the projection mechanism, and the use of the Semi-directed Interview, which would have the student act more naturally. This would allow us to observe the student's posture, reactions and the content of his/her answers at a conscious level.

We have found that the student had varied perceptions in relation to Picture 1 stimulus and they presented several reparation combinations at an unconscious and conscious level.

Based on the reparation suggested by Bohoslavsky, two other types of reparation were included for us: authentic/manic and manic/authentic, by means of clinical study, due to the functioning of mental dynamics, in which we have examined the elements mentioned in the stories, the context where these stories took place, how the account was given and the sort of suggestion offered.

Through the analysis of the answers, we have verified that what was displayed at a conscious level regarding the psychologist career choice not always coincide with the unconscious level. This reveals the importance of taking the question of the unconscious content existing in that choice into consideration.

Keywords: Unconscious motivation. Psychologist education. Psychology. Occupation choice. Content analysis. Klein, Melanie, 1882-1960. 


\section{LISTA DE TABELAS}

TABELA 1 - Percepção da Prancha 1 do TAT - Relação da percepção ObjetivoEstímulo - grau de projeção, deformação ou negação do estímulo

TABELA 2 - Tipos de reparações encontradas nas respostas dadas na Prancha 1 do TAT

TABELA 3 - Tipos de reparações encontradas nas respostas dadas na Entrevista Semidirigida

TABELA 4 - Relação entre a percepção da Prancha 1, das reparações na Prancha 1, das reparações na Entrevista Semidirigida, do número de alunos e a porcentagem 


\section{SUMÁRIO}

\section{RESUMO}

ABSTRACT

LISTA DE TABELAS

CAPÍTULO 1

1.1 Introdução

1.2 Objetivos e Justificativa

1.3 Hipóteses Levantadas

CAPÍtULO 2

2.1 Fundamentação Teórica

CAPÍTULO 3

3.1 A Escolha Profissional: Identificação e Identidades

3.2 A Identidade Vocacional

3.3 Reparação

3.4 A Identidade Profissional do Psicólogo

CAPÍtulO 4

4.1 O Mito de Édipo e a Escolha Profissional 
CAPÍtUlO 5

5.1 O Uso do TAT

CAPÍTULO 6

6.1 A Entrevista Semidirigida

CAPÍTULO 7

7.1 Método

CAPÍTULO 8

8.1 Apresentação e Análise dos Resultados

CAPÍtulo 9

9.1 Conclusão

Referências

Anexo A - Relato das Perguntas e Respostas da Entrevista Semidirigida 


\section{CAPÍTULO 1}

\subsection{Introdução}

Desde que comecei a estudar Psicologia, ficou-me uma pergunta no ar: o que motiva a busca dessa profissão?

No decorrer da minha vida profissional, como psicólogo clínico, fui cada vez mais me deparando com a necessidade do tripé de formação, ou seja, a supervisão, o estudo de um aporte teórico e a análise pessoal; com a supervisão, levando as sessões a serem supervisionadas, fui me deparando com a dificuldade de estar compreendendo a dinâmica que acontecia com os pacientes, tendo sido ajudado no desenvolvimento do olhar e da escuta analítica pelos supervisores; no estudo do aporte teórico fui me deparando com minha ignorância e o quanto eu precisava continuar estudando para poder olhar e compreender os fenômenos mentais de meus pacientes que se presentificavam durante as sessões debaixo de meus olhos e, por fim a necessidade da análise pessoal, me defrontando com meu mundo interno e dinâmica mental, o que não é nada fácil, pois muitas vezes me remetiam a tomar consciência de fatos dolorosos, bem como separar "o joio do trigo", no sentido de discriminar conteúdos meus dos conteúdos dos pacientes.

Com a vivência sine qua non desse tripé, fui me conscientizando cada vez mais dessa pergunta intrigante: "O que nos leva a buscar a profissão de psicólogo, uma vez que a mesma nos remete a lidar constantemente com a loucura, com o sofrimento mental humano, com a desagregação do funcionamento mental das pessoas?" Tentar compreender isso é no que se baseia esta dissertação.

Com o amadurecimento, desenvolvimento profissional e pessoal que fui tendo no decorrer das minhas experiências com os pacientes, chegou o momento em que tal indagação pôde ser transformada numa hipótese investigativa, a ser pesquisada. 
Mediante levantamento bibliográfico condizente, pude constatar que existem alguns estudos que falam sobre a escolha da profissão de psicólogo, mas a nível manifesto, consciente e no aspecto social e o que me interessa é poder atingir um estágio mais profundo desse entendimento, denominado latente, inconsciente.

O próximo passo, após ter pensado o tema da dissertação, foi escolher os sujeitos e instrumentos que poderiam ajudar-me nessa pesquisa e decidi optar por estudantes de primeiro e segundo anos de Psicologia, uma vez que resolvi utilizar como instrumento investigativo a prancha número um do TAT (Thematic Apperception Test) e uma entrevista semidirigida, objetivando com isso chegar a uma compreensão entre os conteúdos latente e manifesto, não perdendo de vista a questão das motivações inconscientes.

Como fazer para operacionalizar o encontro com esses alunos? Uma das possibilidades foi tentar ir às faculdades que tinham o curso de Psicologia e entrar em contato com os mesmos, explicando o objetivo da pesquisa e como seria a participação deles, uma vez que concordassem em serem sujeitos da mesma, com a assinatura do termo de consentimento ao final.

Algumas situações acabaram acontecendo na tentativa de adentrar em algumas faculdades de Psicologia com essa finalidade.

A primeira tentativa foi a de telefonar e falar com o setor de Psicologia de algumas faculdades particulares de São Paulo - Capital - e ver a possibilidade de concretizar a pesquisa; solicitei que agendassem um contato pessoal com o responsável, para que eu pudesse apresentar-me e explicar o objetivo da pesquisa e a possibilidade de poder contar com a autorização e consentimento da faculdade para conversar com os alunos.

Foi então pedido que eu enviasse uma síntese do meu projeto de pesquisa, enfocando principalmente os objetivos, metodologia, instrumentos e população a qual se destinava, para que isso fosse encaminhado ao Conselho de Ética da Instituição e dessem o parecer e possível consentimento; isto feito, fiquei no aguardo da resposta. 
Passado um tempo, como não obtive resposta, entrei em contato novamente com as mesmas, sendo então colocado que por exigência do Conselho Regional de Psicologia, eu deveria enviar um parecer da Comissão de Ética da Instituição a qual eu estava ligado, no caso a USP, dando seu aval de aprovação sobre meu projeto, pois sem isso, ficaria inviabilizada qualquer tramitação.

Quando comuniquei o fato à minha orientadora, foi-me colocado que até esse momento não existia no IPUSP (2003) - Instituto de Psicologia da Universidade de São Paulo uma Comissão de Ética formada, estando a mesma se constituindo; mesmo sendo isto comunicado às Instituições que procurei, não tive acesso aos alunos; umas chegaram a se pronunciar me dizendo de tal impedimento e outras, se quer responderam.

E agora como fazer, se as próprias Instituições que formam psicólogos não me permitiram acesso aos alunos?

Consegui com dois professores do curso de graduação do IPUSP ir até as salas de primeiro e segundo anos de Psicologia e expor meu projeto diretamente aos alunos, colocando que os interessados em participar poderiam entrar em contato comigo através de e-mail ou telefone; concomitante, fui falando com colegas psicólogos e com pessoas que pudessem me indicar alunos que estivessem cursando primeiro e segundo anos de Psicologia.

A partir disso começaram a se apresentar alguns alunos do IPUSP, bem como alunos de outras faculdades e que por ironia, alguns estavam cursando as Instituições que não me possibilitaram a entrada por meios oficiais.

Os alunos do IPUSP foram chegando de modo tímido, cauteloso e após conversar com eles mais de próximo sobre a pesquisa, fazendo um rapport e deixando-os à vontade, foram se descontraindo e fui introduzindo a Prancha 1 do TAT e a entrevista semidirigida; após a leitura e assinatura do Termo de Consentimento, continuávamos a conversar, onde eles mostraram empatia e muitos começaram a comentar vivências pessoais, bem como dúvidas referentes à profissão de Psicólogo, fatos que transcenderam a coleta de dados. 
A partir daí, os próprios alunos que participaram da pesquisa foram indicando outros colegas, incentivando-os a também colaborar nesse projeto.

Observei dois fatos interessantes: no final da entrevista, a maioria dos alunos começou a se colocar de modo muito pessoal e íntimo, bem como o incentivo que eles deram aos seus colegas, no sentido de também participarem da pesquisa, de modo entusiasmado e enfatizando minha postura; exemplo disso, comentários tipo "você tem que participar, porque o Antonio é muito legal”; "vai lá e veja como é bom saber de coisas da nossa profissão, pois o Antonio explica de modo claro", etc.

Um dos alunos participantes, passados alguns dias, procurou-me perguntando se eu saberia dizer algo sobre outras faculdades de Psicologia, pois ele talvez não pudesse mais continuar freqüentando o IPUSP, uma vez que seus pais não teriam como mantê-lo e que precisaria trabalhar; outro veio me pedir indicação de análise, pois não estava bem e precisava de ajuda psicológica.

Com tudo isto, questionei-me o que haveria acontecido para tais manifestações, pois foi algo que não estava sendo esperado e que surpreendentemente apareceu durante a coleta do material.

Fui percebendo que eu havia transcendido ao papel de aplicador científico e acolhido esses alunos em suas angústias, inclusive referindo-me a eles como futuros colegas de profissão e ouvindo-os acima de tudo.

Acredito que nesse contexto acabei exercendo as funções materna e paterna pelo fato de ouvi-los sem crítica, sem moralismo, de modo humano, propiciando uma maior projeção de seus conteúdos manifestos e latentes, cabendo aqui o conceito de holding proposto por Winnicott. De acordo com Lehman (1996):

Winnicott é um dos autores que ressalta a influência do meio ambiente como possível facilitador ou comprometedor do desenvolvimento (em Bion temos a noção de revèrie). A importância e a qualidade do holding (sustentação) enfoca a influência decisiva do meio ambiente facilitador. Em outras palavras, ressalta a importância 
do papel da mãe capaz de uma adaptação às necessidades do bebê para um desenvolvimento de seu $\mathrm{Eu}$ (Ego). Os processos maturacionais inatos, num primeiro momento de dependência absoluta do meio, necessitam de um meio facilitador capaz de se adaptar ao bebê. Falhas neste meio interferem no desenvolvimento posterior, podendo levar à distorções da organização Indivíduo/Ambiente”. (p. 277-278)

Sem dúvida minha escuta e olhar se devem aos anos de experiência, formação, estudo teórico e análise pessoal que tenho nessa área, fato que fica intrínseco em minha maneira de ser.

Ter uma postura científica não significa desconsiderar ou mesmo cindir a relação humana da pesquisa, pois acima de tudo, havia dois seres humanos se inter-relacionando naquele momento, dentro daquele espaço físico e mental.

Passaremos agora aos objetivos e justificativa desta pesquisa.

\subsection{Objetivos e Justificativa}

Esse trabalho tem por objetivo verificar quais as motivações inconscientes que permeiam um jovem a escolher a profissão de psicólogo, bem como a relação entre o material consciente (verbal) e o resultado do TAT, através da coleta de dados dos estudantes de primeiro e segundo anos de Psicologia.

Através do aporte teórico psicanalítico kleiniano apontarei as questões da identidade pessoal, ocupacional e vocacional inerentes a essa escolha profissional. O histórico pessoal das primeiras relações objetais, ansiedades e defesas, têm importância capital não só para a identidade pessoal, mas também profissional, funcionando essa última como projeção da primeira, uma vez que as vicissitudes decorrentes dessas relações 
objetais é que de alguma maneira, vão permear as identidades. Onipotência e arrogância acabam muitas vezes estando presentes na pseudo-reparação, como impeditivos de "um olhar para dentro de si", diferente da reparação autêntica, onde o ego desenvolveu a capacidade de tolerar a frustração e, portanto, esta pessoa está em melhores condições de funcionamento mental e conseqüentemente em escolher uma profissão não por defesa e sim, por capacidade egóica. Esses conceitos sobre reparação autêntica e pseudo-reparação serão desenvolvidos mais adiante, quando for tratada a questão da reparação.

De alguma maneira na vocação está implícita a questão da identidade profissional e ocupacional, como uma conquista para a reparação. No levantamento bibliográfico feito sobre o tema dessa pesquisa, dentro da Psicologia, foram encontrados poucos trabalhos que versam sobre a questão da identidade profissional do psicólogo, dentro e fora do Brasil. Os artigos encontrados abordam mais os aspectos sociais e estatísticos.

Essa pesquisa pretende contribuir com os profissionais da área de Psicologia e áreas afins, oferecendo uma visão mais voltada à investigação dos aspectos inconscientes da escolha profissional realizada pelo psicólogo. Na literatura encontramos trabalhos que voltam-se, em geral, à abordagem dos aspectos sociais e conscientes relacionados à escolha dessa carreira. A proposta apresentada nesta pesquisa, mostra-se mais eficaz para o encaminhamento de um projeto profilático, uma vez que procura elucidar o modo como a escolha pela Psicologia é realizada, em que moldes e em que condição ela ocorre, revelando o sentido e objetivo de escolher tal profissão.

\subsection{Hipóteses Levantadas}

Partindo da premissa kleiniana de que quando se escolhe uma profissão está se reparando um objeto destruído em fantasia, ou na realidade, procuraremos perceber se houve tal reparação; e em havendo, de que tipo ela se mostra. Segundo Bohoslavsky (1982), se é uma reparação autêntica, pseudo-reparatória, compulsiva, etc. 
Algumas questões são levantadas: Em que condição mental o indivíduo se apresenta para identificar-se com as figuras parentais e poder a partir daí, ir construindo sua identidade pessoal e, posteriormente, profissional? Será que dentro de uma posição esquizoparanóide o indivíduo só consegue fazer uma pseudo-reparação na escolha profissional e estando na posição depressiva, uma reparação autêntica? Em que condições um ego frágil e aprisionado em seu desenvolvimento poderá reparar autenticamente seus objetos internos destruídos? Quando uma pessoa escolhe a profissão de psicólogo em que está implícita a sua identidade profissional, que objetos internos danificados ela está tentando reparar?

Estas e muitas outras questões precisam ser pensadas e discutidas em investigações e pesquisas. Além disso, ficam como preocupação para professores e formadores de psicólogos, em especial. Estamos nos referindo aos cursos de graduação, e também aos demais, como pós-graduação e especialização. Ou seja, na formação do psicólogo e na discussão do exercício da profissão, é preciso ter claro esses elementos da personalidade dos profissionais e como encaminhar trabalhos que auxiliem nessa formação, que é muito mais ampla do que acumular conhecimentos teóricos. 


\section{CAPÍTULO 2}

\subsection{Fundamentação Teórica}

Este estudo vem atender ao meu interesse em detectar quais as motivações inconscientes que estão presentes na escolha da profissão de psicólogo, já que tal profissão é árdua por ter o profissional que prestar-se a ser a tela de projeção do paciente, tanto em seus aspectos idealizados, quanto persecutórios e de alguma forma, acolher todas essas projeções, como também ser continente no desespero e angústia revelados pelo mesmo. O tempo todo o psicólogo está lidando com o sofrimento e o mundo mental do paciente e para isso, precisa ter algo que faça com que ele continue em sua função e papel e, é exatamente compreender este mecanismo inconsciente que o leva a escolher essa profissão o meu foco de interesse; nisso é que está baseado meu estudo, sendo os instrumentos escolhidos para pesquisar tais aspectos, a Prancha 1 do TAT e a Entrevista Semidirigida.

Segundo a teoria kleiniana, as relações objetais que vão se desenvolvendo desde o início de nossas vidas irão por si desencadear fantasias inconscientes, ansiedades, gerar defesas e, durante toda a vida, vamos oscilar entre as posições esquizoparanóide e depressiva, de acordo com as condições momentâneas em que o ego vai se encontrar de maior ou menor capacidade de integração.

Vamos aclarar alguns desses conceitos.

Melanie Klein no prefácio da terceira edição inglesa escrita em maio de $1948 \mathrm{em}$ seu livro "A Psicanálise de Crianças" (KLEIN, 1981b) diz:

... O termo "posição" foi escolhido, porque, embora os fenômenos envolvidos ocorram primeiramente durante estágios arcaicos de desenvolvimento, eles não estão confinados a esses estágios, mas 
representam agrupamentos específicos de ansiedades e defesas que aparecem e reaparecem durante os primeiros anos de infância“. (p. 13)

Hanna Segal (1975) escreve:

Todavia Melanie Klein escolheu o termo "posição" para dar ênfase ao fato de que o fenômeno descrito não era simplesmente um "estádio" passageiro ou uma "fase", como, por exemplo, a fase oral; o termo escolhido implica em uma configuração específica de relações de objeto, ansiedades e defesas, que persistem durante toda a vida. (p. 11)

Temos a definição de Fantasia Inconsciente no verbete de Hinshelwood (1992) que é a seguinte:

As fantasias inconscientes estão subjacentes a todo processo mental e acompanham toda a atividade mental. Elas são a representação mental daqueles eventos somáticos no corpo que abrangem as pulsões, e são sensações físicas interpretadas como relacionamentos com objetos que causam essas sensações. Irrompendo a partir de sua instigação biológica, as fantasias inconscientes são lentamente transformadas por duas maneiras: (i) pela mudança através do desenvolvimento dos órgãos para a percepção à distância da realidade externa, e (ii) pelo surgimento do mundo simbólico da cultura, a partir do mundo primário do corpo. As fantasias podem ser elaboradas para alívio dos estados internos da mente, quer pela manipulação do corpo e suas sensações (fantasias masturbatórias), quer pelo fantasiar direto. A fantasia é a expressão mental das noções pulsionais e também dos mecanismos de defesa contra essas noções pulsionais. (p. 46)

As posições esquizoparanóide e depressiva constituem momentos singulares da evolução psíquica; são mais precisamente subdivisões do estádio oral, com a primeira posição estendendo-se do nascimento aos três ou quatro primeiros meses de vida e a segunda aos últimos seis meses do primeiro ano. São modalidades originais de relações 
objetais e específicas de certos tipos de angústias e de defesas; essas posições têm um alcance muito mais vasto e podem verificar-se em diferentes períodos da vida.

Além do mais o estabelecimento de uma nova posição não suprime totalmente a ação dos mecanismos e das operações psíquicas ligadas à anterior: o desenvolvimento normal testemunha, na realidade, uma constante oscilação de uma posição à outra, segundo um movimento de fluxo e refluxo ou à escolha de regressão e progressão. É, aliás, a própria lei do progresso psicológico. Cada uma das fixações e cada um dos sintomas que aparecem, de modo geral, nos estádios sucessivos do desenvolvimento tem ao mesmo tempo uma função retrospectiva e prospectiva.

Cabe aqui falarmos sobre as posições esquizoparanóide e depressiva de maneira um pouco mais detalhada.

A partir do nascimento como o bebê é um ser pulsional, ele nasce com a pulsão de vida e de morte o que o leva a um conflito de imediato entre as pulsões, incrementado pelas condições do próprio nascimento.

Como seu ego é lábil, ele tem que de alguma maneira livrar-se desse incômodo, dessa ansiedade, denominada então de ansiedade persecutória de aniquilamento, pois sua vivência emocional é de que ele será aniquilado; seu ego cinde (se divide), sendo que parte da pulsão de morte será defletida para o exterior e parte permanecerá dentro do aparelho psíquico, transformando-se em agressividade.

Como seu primeiro objeto real é o seio materno, então essa parte da pulsão de morte defletida será dirigida a esse seio, o qual será investido de perseguidores; ao mamar ele irá introjetar esses perseguidores, fantasiando que é o seio que o está perseguindo e querendo destrui-lo e não a introjeção de suas próprias vivências que foram ali depositadas. A parte da pulsão de morte que ficou dentro do aparelho servirá para combater esses objetos internos perseguidores.

Com relação a pulsão de vida, ou seja com a libido, ocorrerá o mesmo; parte dela será defletida sobre o seio materno e parte ficará dentro do aparelho psíquico; a introjeção desse seio depositário dos aspectos bons acontecerá quando ele também mamar, sendo 
então incorporado os aspectos ideais; parte da pulsão de vida que permaneceu dentro do aparelho servirá para libidinizar os objetos externos e internos.

Os objetos ideais e persecutórios introjetados na posição esquizoparanóide vão formar as primeiras raízes do superego e a partir da introjeção tanto dos objetos ideais, quanto persecutórios, passará agora acontecer a projeção dessas vivências.

Petot (1992) diz:

Em suma, a interiorização-introjeção é um processo fundamental da vida psíquica. Não se interrompe jamais. É realizada nas e através das fantasias de incorporação que acompanham, prolongam ou repetem numa forma alucinatória as condutas corporais de devoramento. A introjeção pode não ser seguida de reprojeção do objeto: é então bemsucedida e o objeto instala-se no ego. Esse sucesso parece ter como fator principal a identificação como o bom objeto que permite passar da simples ligação libidinal ao verdadeiro amor pelo objeto, a menos que ela não se confunda pura e simplesmente com esse mecanismo. (p. 31)

Toda vivência de frustração que esse bebê terá, será vivida como um seio mau e persecutório e toda vivência de gratificação será vivida como seio bom; havendo uma percepção parcial de objetos, pois não há ainda por parte do bebê uma distinção entre ele e a outra pessoa e sim uma relação boca - seio, para posteriormente transformar-se em filho - mãe.

Quando o bebê tem fome, dor ou outra vivência qualquer de desconforto gerando-lhe angústia, imediatamente ele começa a chorar, uma vez que precisa livrar-se disto; a mãe estando em sintonia com ele, saberá decodificar esse choro e atendê-lo em suas necessidades; isso é chamado de Identificação Projetiva, pois o bebê projetou seu desconforto e angústia e sua mãe pôde identificar-se com isto e traduzir em palavras o que essa vivência estava mostrando; por essa razão a Identificação Projetiva é considerada a forma mais primitiva de comunicação do ser humano. 
No caso desse bebê não poder ser atendido de imediato por sua mãe, sua vivência será de frustração; dependendo da intensidade e tolerância dele, às vezes ele pára de chorar e observa-se que ele está com movimentos de sucção como se estivesse mamando, sem a presença real do seio, fenômeno esse nomeado como gratificação alucinatória.

Se a mãe lhe oferece o seio nesse momento, muitas vezes ele rejeita, inclusive virando a cabeça para afastar-se do mesmo, uma vez que sua vivência passa a ser não como um oferecimento de um seio bom, mas de um seio que lhe frustrou, portando um seio mau; com a devida paciência, tolerância e amor advindos da mãe, ela poderá suportar essa rejeição do filho e calmamente continuar oferecendo-lhe, até que ele possa aceitar e começar a mamar.

Essa condição da mãe irá propiciar uma mitigação das vivências persecutórias do bebê, pois os objetos bom e mau poderão ir gradativamente se aproximando uns dos outros, sendo que antes, se quer, podiam aproximarem-se; dito de outro modo, a mãe irá ajudar seu bebê a tolerar mais a frustração, não precisando projetar tanto sua angústia que nesse momento é persecutória, pois quanto mais ele projeta, mais debilitado, enfraquecido e sem recursos vai ficando seu ego, e podendo tolerar a angústia, terá a possibilidade de lidar com ela, bem como elaborá-la, permitindo com isto um novo modo de funcionamento mental e conseqüentemente, nova ansiedade será vivida, agora a ansiedade depressiva.

Essa passagem é muito delicada, pois a condição básica da passagem da posição esquizoparanóide para a posição depressiva é de que as experiências de gratificação superem as de frustração.

O ponto de fixação da doença psicótica está na posição esquizoparanóide e no início da posição depressiva; quando ocorre a regressão a pontos primitivos do desenvolvimento, perde-se o sentido de realidade e o bebê terá um funcionamento psicótico; se a posição depressiva foi alcançada e pelo menos parcialmente elaborada, as dificuldades encontradas no desenvolvimento posterior do bebê não serão de natureza psicótica, mas neurótica. 
Passando para a posição depressiva, novas vivências irão ocorrer: a angústia que antes era persecutória agora passa a ser depressiva, os objetos bom e mau que estavam afastados um do outro passam agora a se aproximarem, ou seja, há um ganho de percepção, os objetos que antes eram parciais, agora são percebidos como objetos totais, isso mostra que houve uma integração perceptual.

Melanie Klein (1996c) diz textualmente: “... Por outro lado, através da identificação com um objeto bom e com todos os avanços mentais que isso implica, o ego se vê obrigado a ter uma noção mais completa da realidade psíquica, o que o expõe a conflitos violentos" (p. 307).

Essa integração traz sentimentos novos e desconhecidos, são eles: culpa, ambivalência, luto e reparação.

O ganho perceptual vai proporcionar ao bebê a visão total dos objetos e aquele objeto que ele tanto atacou quando frustrado em suas expectativas, que é o seio materno - a própria mãe - ele passa a reconhecer que é o mesmo objeto que lhe gratificou também; ele percebe que estava atacando a fonte que lhe deu a vida.

Exatamente essa percepção lhe trará um sentimento de culpa muito grande, bem como uma ambivalência, pois ele não sabe se destruiu ou não esse objeto que lhe deu a vida; sua vivência emocional é a de ter destruído (em fantasia) o objeto bom e para que a culpa não se torne insuportável, tenta reparar esse objeto; fazendo isso ele está criando um novo objeto e ao mesmo tempo, mitiga seu sentimento de culpa.

Tudo isto é vivido de modo muito sofrido; o sofrimento do luto experimentado na posição depressiva e os impulsos reparadores desenvolvidos para restaurar os objetos amados tanto internos, quanto externos, vão constituir a base da criatividade e da sublimação.

O desejo por recriar seus objetos perdidos em fantasia propicia o impulso para recompor o que foi feito em pedaços, possibilita a reconstrução do que foi destruído, para recriar; concomitante a isso, seu desejo de preservar seus objetos bons leva-o a sublimar seus impulsos quando sentidos como destrutivos. 
As repetidas experiências de luto e reparação vividas pelo bebê vão possibilitando que seu ego se torne enriquecido pelos objetos que ele teve que recriar dentro de si próprio e ao mesmo tempo, tornando-se parte dele.

Com essa evolução de suas vivências, estará mais capacitado a não precisar mais projetar tanto, livrar-se tanto de suas angústias, passando a utilizar-se de outros mecanismos, a inibição, repressão e o deslocamento, mecanismos esses de natureza neurótica.

A posição depressiva não é plenamente elaborada e sim parcialmente, pois caso fosse plenamente, seria feita na base da onipotência do objeto e ao mesmo tempo se atingiria a perfeição com relação a bondade, perdendo-se com isso a condição de ser humano.

Gradativamente quando se vai adquirindo conhecimento, resultado de um estado de maior integração do ego, isto propiciará ao mesmo uma resignificação dos acontecimentos, tanto da realidade externa, quanto da realidade interna, dando-lhe consciência até então desconhecida e o levará a conflitos terríveis, justamente por tal ganho de percepção, uma vez que anteriormente as coisas já estavam presentes na vida do sujeito, embora ele não tivesse consciência disso.

A partir do momento no qual o bebê é devidamente acolhido em sua angústia pela(s) pessoa(s) que exerça(m) as funções materna e/ou paterna, em que o amor possa superar os momentos de desespero, ou seja, que haja predominância das experiências boas sobre as más, há a possibilidade da introjeção do objeto bom na posição esquizoparanóide, que formará o núcleo do ego e que possibilitará ser o alicerce emocional dessa criança, para que ela tenha condições de lidar com as adversidades da vida, bem como perceber a diferença entre o real e o ideal, aceitando ou convivendo com isso.

Estamos adentrando a questão da identificação, bem como das identidades que o indivíduo vai tecendo e alicerçando no decorrer desse desenvolvimento; a seguir vamos explicitar melhor esta questão. 


\section{CAPÍTULO 3}

\subsection{A Escolha Profissional: Identificação e Identidades}

Quando falamos sobre identidade, seja ela pessoal, profissional, vocacional, segundo o aporte teórico psicanalítico kleiniano, nos remetemos às primeiras relações objetais, ansiedades e defesas com os mais primitivos objetos: as figuras parentais.

Não podemos falar sobre identidade sem antes falarmos sobre identificação e portanto vamos fazer um breve comentário sobre a questão da identificação segundo a teoria de Freud.

O ser humano é o único animal que nasce totalmente dependente em todos os aspectos, sendo que essa dependência se prolonga por um longo tempo, bem diferente de outras espécies animais que em tempo breve são levadas a se independizarem, tendo que se cuidarem por si próprias.

Diferente também de outras espécies animais, o ser humano só pode ser constituído psicologicamente por outro ser humano, por outro semelhante e esse processo denomina-se identificação, que está ligado ao narcisismo, havendo dois tipos de identificação em Psicanálise, a chamada identificação primária e a identificação secundária.

A identificação primária caracteriza-se por um estágio de indiferenciação entre o self e o objeto, onde o ser humano nasce psicologicamente fusionado com o outro ser humano; essa dependência e não distinção dele com o outro faz com que ele fique identificado com esse outro.

Estando no mais puro narcisismo nesse momento, seu diferencial será o sentir prazer/desprazer e através dessas vivências, começará a construir seu ego, bem como os objetos, ficando com o prazer e livrando-se do desprazer. 
No seu artigo Freud (1914/1987) escreve o seguinte:

(...) Se prestarmos atenção à atitude de pais afetuosos para com os filhos, temos de reconhecer que ela é uma revivescência e reprodução de seu próprio narcisismo, que de há muito abandonaram. O indicador digno de nota constituído pela supervalorização, que já reconhecemos como um estigma narcisista no caso da escolha objetal, domina, como todos nós sabemos, sua atitude emocional.

Assim eles se acham sob a compulsão de atribuir todas as perfeições ao filho - o que uma observação sóbria não permitiria - e de ocultar e esquecer todas as deficiências dele. (Incidentalmente, a negação da sexualidade nas crianças está relacionada a isso.) Além disso, sentemse inclinados a suspender, em favor da criança, o funcionamento de todas as aquisições culturais que seu próprio narcisismo foi forçado a respeitar, e a renovar em nome dela as reivindicações aos privilégios de há muito por eles próprios abandonados. A criança terá mais divertimentos que seus pais; ela não ficará sujeita às necessidades que eles reconheceram como supremas na vida. A doença, a morte, a renúncia ao prazer, restrições à sua vontade própria não a atingirão; as leis da natureza e da sociedade serão ab-rogadas em seu favor; ela será mais uma vez realmente o centro e o âmago da criação - 'Sua Majestade o Bebê, ${ }^{1}$, como outrora nós mesmos nos imaginávamos. A criança concretizará os sonhos dourados que os pais jamais realizaram - o menino se tornará um grande homem e um herói em lugar do pai, e a menina se casará com um príncipe como compensação para sua mãe. No ponto mais sensível do sistema narcisista, a imortalidade do ego, tão oprimida pela realidade, a segurança é alcançada por meio do refúgio na criança. $\mathrm{O}$ amor dos pais, tão comovedor e no fundo tão infantil, nada mais é senão o narcisismo dos pais renascido, o qual transformado em amor objetal, inequivocamente revela sua natureza anterior. (p. 107-108)

\footnotetext{
${ }^{1}$ Em inglês no original: 'His Majesty the Baby'. Talvez uma referência a um conhecido quadro da era eduardiana, da Academia Real, que trazia aquele título e mostrava dois policiais londrinos interrompendo o tráfego intenso para deixar que uma babá atravessasse a rua empurrando um carrinho de criança. - 'Sua Majestade o Ego' aparece no artigo anterior de Freud sobre 'Creative Writers and Day-Dreaming' (1908e).
} 
Vemos nessa citação que se os pais não conseguirem lidar com seu narcisismo, não possibilitarão aos seus filhos também lidarem, pois esses filhos continuarão sendo a extensão deles próprios como filhos idealizados e não como seres individualizados, diferentes dos pais.

No que se refere a "Sua Majestade o Bebê", há a necessidade da criança perceber que isso é uma grande ilusão, pois o mundo não existe só porque ela nasceu e quem deve mostrar isso a ela são os próprios pais também, onde num primeiro momento mostram que ela é o centro do mundo, para depois mostrarem que existem outros interesses por parte dos mesmos, não sendo ela o único, como por exemplo o amor entre eles, o trabalho, a hora de lazer, etc; é necessário primeiro iludir, para depois desiludir.

Isso faz com que a criança passe agora para a identificação secundária, ligada à questão da castração.

Aqui começa existir a diferenciação entre eu e o outro, entrando portanto, na questão da triangularidade edípica.

Até então seus desejos eram gratificados pelos pais, mantendo esse ser em seu narcisismo, mas agora quando o desejo sexual do menino pela mãe e da menina pelo pai se presentifica, tais desejos são negados; a cultura se impõe através da proibição do incesto, constituindo portanto a identificação secundária, ou seja, o superego.

Freud (1920/1987) escreve:

Ao mesmo tempo que esta identificação com o pai, ou pouco depois, o menino começa a desenvolver uma catexia de objeto verdadeira em relação à mãe, de acordo com o tipo (anaclítico) de ligação. Apresenta então, portanto dois laços psicológicos distintos, uma catexia de objeto sexual e direto para com a mãe e uma identificação com o pai que toma como modelo. Ambas subsistem lado a lado durante certo tempo, sem qualquer influência mútua. Em consequiência do avanço irresistível no sentido de uma unificação da 
vida mental, elas acabam por unir-se e o complexo de Édipo normal origina-se de sua influência. (p. 133)

Freud (1920/1987) continua em outro parágrafo:

É fácil enunciar numa fórmula a distinção entre identificação com o pai e a escolha desse como objeto. No primeiro caso, o pai é o que gostaríamos de ser, no segundo, o que gostaríamos de ter, ou seja, a distinção depende do laço se ligar ao sujeito ou ao objeto do Ego. O primeiro tipo de laço, portanto, já é possível antes que qualquer escolha sexual de objeto tenha sido feita. (p. 134)

Assim sendo, para que esse ser se livre da castração, ele vira as costas ao Édipo, abdicando do seu objeto de desejo pelo sexo oposto, identificando-se com o objeto do mesmo sexo que o seu; ou seja, no Complexo de Édipo, a catexia em direção ao pai exclui a identificação com ele; quando o sujeito está identificado com a mãe, a catexia do objeto escolherá o pai e vice-versa.

Mediante ao exposto, poderemos agora fazer um paralelo com a questão da escolha profissional.

Toda escolha profissional subentende um conjunto de fatores que nela estão implícitos, entre eles a questão da(s) identidade(s), ou seja, a identidade pessoal, vocacional e profissional.

O papel da família tem um peso significativo para essa formação da(s) identidade(s), uma vez que os pais vão servir de modelo para os filhos; tenho observado que os pais, de modo geral, estão cada vez mais temerosos e perdidos no que diz respeito à educação dos filhos, não sabendo como e nem quando interceder nas atitudes e comportamentos que se passam debaixo de seus olhos, vindo buscar respaldo com o psicólogo. Os pais tanto podem facilitar, como dificultar o modelo a ser adquirido pelos filhos, pois há pais que são mais acolhedores, compreensivos, que conseguem ficar no papel de frustradores e com isso acabam propiciando o holding para os filhos, enquanto outros, menos acolhedores, menos compreensivos, não podem, se quer, propiciar o holding aos filhos; 
não é infrequente pais atrapalharem seus filhos a se independizar, conservando-os na dependência deles. Em contrapartida, também vemos filhos que se acomodam a tais situações de dependência, pois acabam tendo um ganho secundário, o que os mantém atados e paralisados sem seus desenvolvimentos, bem como também vemos filhos que conseguem romper tal situação de dependência. Na adolescência, principalmente, há o momento dos filhos "castrarem" os pais, deixando claro que não são mais crianças e que estão adquirindo suas próprias identidades e desvinculando-se daquela relação pais-filho que antes era necessária, mas que passa a acontecer em outros moldes relacionais.

Vemos aqui a questão da singularidade que há no ser humano, uma vez que a somatória de toda essa bagagem e vivências terão aspectos ambientais externos, bem como das condições internas de cada um, devido a tal singularidade; em suma podemos dizer que entre os fatores que fazem parte desse processo estão a questão do status social que a profissão traz, características de personalidade de quem escolhe, identificações em seu meio social e afetivo, ideal de ego, superego e ao próprio ego com seus mecanismos de defesa, como também não podemos generalizar explicações a respeito de determinadas escolhas como sendo universais, devemos tentar compreender qual o significado da profissão escolhida e o que ela representa para cada sujeito.

Um dos conceitos a ser pensado é a questão do que é educar, onde os pais clamam por receitas prontas com regras precisas e claras. É de nossa responsabilidade transmitir os valores mínimos às crianças para que elas possam viver em sociedade; é prepará-las para as adversidades que a vida nos impõe no dia-a-dia, alicerçando-as e para isso não há outra maneira a não ser deixá-las nas situações difíceis, pois só assim poderão desenvolver suas capacidades e não retirá-las ou impedi-las dessas vivências, caso façamos isso estaremos considerando-as incapazes de premissa.

E o que é disciplina? Entre outras coisas “instrução a ser transmitida a discípulos”. Cabe agora perguntar: e o que é discípulo? É uma palavra que vem do latim “discípulus", que significa "aquele que aprende".

Os filhos são os discípulos de seus pais, pois é com eles que vão aprender e para que esse aprendizado ocorra, eles precisam admirá-los, seguir seus exemplos, identificaremse com eles através de um contato assíduo e próximo, pois inicialmente, precisam seguir 
os modelos que os pais estão mostrando, que são vistos e vividos em seus ambientes familiares e não impostos pela autoridade, para posteriormente adquirirem suas próprias identidades.

Se uma criança não puder admirar seus pais, então como conseguirá identificar-se com eles? Daí a necessidade de procurar outros modelos identificatórios de pessoas que possam ser admiradas; caso isso falhe ou gere modelos identificatórios prejudiciais, temos como exemplo disso as gangues de delinqüentes, onde um dos pontos em comum entre eles é justamente a falta de modelos identificatórios; se a criança tiver dentro de seu lar um clima amistoso, de calor humano e de amor, poderá desenvolver-se de modo sadio e disciplinado.

Pais que se respeitam não precisam exigir respeito dos filhos, pois são modelos para os mesmos; disciplina não se impõe, se ensina pelo modelo, requerendo tempo, paciência, confiança e coerência. Por que coerência? Porque comumente, os pais falam uma coisa e mostram outra, sendo isso percebido pelo(s) filho(s).

Este tipo de atitude gera desespero, pois a criança passa a não ter como distinguir e acreditar naquilo que está sendo dito pelos pais; não é confiável, tudo acaba sendo permitido, tudo pode, o que não é verdadeiro, nem tudo pode, há limites na vida e para se estabelecer limites, os pais precisam ficar numa posição muito incômoda e difícil: é agüentar ficar no papel daqueles que frustram.

É comum ouvirmos falar "meu marido sempre fica no papel de bonzinho, porque ele deixa fazer tudo e eu, como mãe, no papel da bruxa que não deixa fazer nada. Será que meu filho vai gostar mais dele do que de mim?". Nessa situação percebemos a cisão clara entre o totalmente bom de um lado e o totalmente mau do outro, não podendo a criança perceber que uma pessoa tanto apresenta tolerância como intolerância diante das situações, tanto a gratificação quanto a frustração fazem parte da atitude de uma mesma pessoa e não uma pessoa ser somente generosa e a outra, só frustradora.

Segundo a teoria kleiniana, as primeiras relações objetais são cruciais para a constituição do mundo mental do ser humano, onde num primeiro momento a percepção de objetos será parcial (posição esquizoparanóide), devido aos mecanismos de cisão, 
projeção, introjeção, idealização, negação e onipotência para posteriormente haver a integração dessa percepção parcial do ego e dos objetos para uma percepção total (posição depressiva), ocorrendo outros mecanismos tais como a mania, repressão, bem como os sentimentos de luto, ambivalência e reparação.

Melanie Klein (1996b) diz:

Uma vez que, sob o domínio da libido oral, o bebê introjeta seus objetos desde o início, as imagos primárias possuem seu equivalente no mundo interior da criança. As imagos do seio da mãe e do pênis do pai se estabelecem dentro do ego e formam o núcleo do superego. À introjeção do seio e da mãe bons e maus corresponde a introjeção do pênis e do pai bons e maus. Eles se tornam os primeiros representantes das figuras internas protetoras e auxiliadoras, de um lado, e das figuras internas persecutórias e retaliadoras, de outro. Essas são as primeiras identificações que o ego desenvolve. (p. 453454)

Vemos neste momento como vai acontecendo o processo de identificação no bebê através dessas relações objetais com as figuras parentais.

Mediante esse ganho de percepção pela integração egóica, onde o objeto passa a ser visto como total e não mais parcial, aqui é que existe a possibilidade de identificar-se com ele, bem como o medo em perdê-lo e Melanie Klein (1996c) escreve:

Quando a criança (ou adulto) se identifica de forma mais completa com um objeto bom, os anseios libidinais aumentam; ela desenvolve amor e desejo vorazes de devorar esse objeto, e o mecanismo de introjeção é reforçado. Além disso, ela se vê impelida a repetir constantemente a incorporação do objeto bom (i.é, a repetição do ato tem o objetivo de testar a realidade dos seus medos e refutá-los), em parte porque teme tê-los perdido por causa de seu canibalismo e também porque tem medo dos perseguidores internalizados, precisando do objeto bom para ajudá-la a combatê-los. Nesse 
estágio, mais do que nunca, o ego é impelido pelo amor e pela necessidade de introjetar o objeto. (p. 306)

Incorporamos as figuras parentais, sociais e ambientais que ficam recalcados no inconsciente e a partir de como foram acontecendo essas relações, teremos as mais variadas vicissitudes no que se refere não só a construção e fundação de nosso aparelho psíquico, mas também as decorrências dessas vivências, incluindo-se a nossa identidade. Teremos, então, a identidade pessoal sendo formada de acordo com tais vicissitudes e a partir disso, a construção da identidade profissional.

Isto nos remete à questão da identidade vocacional; a identidade ocupacional, produto de alguma coisa que se processou na pessoa que escolhe é que determina essa identidade ocupacional, denominada então de identidade vocacional.

Quando uma pessoa pode ter uma maior integração de seus objetos internos de modo que tanto os objetos bons, quanto os maus, possam aproximar-se uns dos outros, o indivíduo começa a tolerar mais essa convivência entre seus objetos, sem precisar livrar-se deles através da cisão e da projeção; Melanie Klein (1996c), como vimos anteriormente, denominou esse funcionamento mental de Posição Depressiva.

Podemos dizer que uma pessoa alcança a identidade ocupacional quando integrou suas diferentes identificações e a identidade vocacional será uma resposta ao para quê e ao porquê da conquista dessa identidade ocupacional.

Claro fica que deve haver uma modificação interna da pessoa, fruto de um amadurecimento, crescimento e desenvolvimento, "um olhar para dentro de si", para que depois essa modificação se exteriorize; por exemplo, uma pessoa que não foi devidamente valorizada quando criança pelos seus pais, sendo criticada em suas qualidades, não acolhida em suas angústias, por defesa a todas essas vivências e sentimentos, poderá tornar-se onipotente, tendo sua auto-imagem idealizada e, por transferência, projetará essa auto-imagem em sua identidade pessoal e por conseguinte, profissional e caso ela "não olhe para dentro de si" e não possa ser conscientizada desse seu funcionamento mental, isso irá estender-se também à sua identidade profissional, 
tornando-a um profissional narcisista, arrogante e onipotente; não devemos nos esquecer que a onipotência encobre a impotência.

A escolha profissional do adolescente é o momento em que ocorrerá o desligamento com relação a dependência juntos aos pais, momento em que ele terá que se firmar nessa escolha e será que a profissão não é a saída do Édipo? Aberastury e Knobel (1985) colocam:

... só quando o adolescente é capaz de aceitar simultaneamente os dois aspectos, o de criança e de adulto, pode começar a aceitar de maneira flutuante as mudanças do seu corpo, e começa a surgir a sua nova identidade. No adolescente a escolha da vocação desperta angústias e o que dificulta a decisão não é a falta de capacidade, mas a dificuldade de renunciar, porque a escolha obtém o significado não de adquirir algo, mas de perder o outro. As modificações em seu corpo levam-no à estruturação de um novo ego corporal à busca de sua identidade e ao cumprimento de novos papéis, tudo que deixa de ser através dos pais para chegar a ser ele mesmo. (p. 66)

Passaremos agora para a questão da Identidade Vocacional.

\subsection{A Identidade Vocacional}

A escolha vocacional por uma profissão acaba transitando por todos esses processos, pois é fruto do desenvolvimento mental do ser humano e cada pessoa terá uma vicissitude nessa evolução de seu mundo mental, devido às relações objetais, ansiedades e defesas, estando aqui o foco de interesse desta pesquisa.

Segundo Bohoslavsky (1982),

Durante muito tempo o conceito vocacional foi considerado como explicativo da escolha de uma carreira ou trabalho. Tinha o valor de 
uma variável independente ou interveniente pelo que remetia a alguma teoria da motivação. Em geral, esta permanecia indefinida, ainda que se falasse vagamente de "tendência", "desejo", "inclinação", "predisposição", “dom”.(p. 72)

De acordo com Bohoslavsky (1983) podemos distinguir entre identidade vocacional e identidade profissional; a identidade vocacional expressa as variáveis afetivoemocional, constituindo a expressão dos impulsos e pedidos reparatórios que surgem no sujeito como respostas à percepção inconsciente de seus objetos danificados e está determinada pela forma do sujeito enfrentar seus lutos, enquanto que a identidade profissional busca o que satisfaz estas necessidades.

A identidade vocacional é determinada por circunstâncias do histórico do sujeito, relacionada com os objetos primários externos e internos, estando sobredeterminada, expressando conflitos e elaboração dos mesmos. Diz Bohoslavsky (1983): "Estes níveis de sobredeterminação ${ }^{2}$ da identidade vocacional permitem explicar o porquê, o para quê e o como de uma determinada vocação.” (p. 62)

Ainda de acordo com o autor acima citado, podemos observar que enquanto a resposta ao porquê, para quê e como da escolha de uma profissão corresponde a identidade vocacional, a resposta ao quando, onde, com quê e como desempenha um papel produtivo na estrutura social corresponde à identidade profissional; falando de outro modo, a identidade vocacional refere-se ao "chamado", ao impulso, uma necessidade a ser satisfeita e a identidade profissional refere-se ao que satisfaz esta necessidade.

Quando uma pessoa “opta” por uma profissão vemos que ela atende aos seus desejos e ao que está sócio-economicamente determinado, já fazendo parte dela através do processo de socialização.

\footnotetext{
2 Entenderei por sobredeterminação a ação de múltiplas e diversas causas convergentes e contraditórias com diferentes valores de determinação sobre efeitos que, neste caso, se articulam numa identidade vocacional ou "autopercepção" de coerência e integridade temporal em termos de papéis produtivos.
} 
O que vai permitir compreender parcialmente e em níveis mais superficiais de sobredeterminação a "escolha" de um estudo ou de uma profissão é a análise das causas do processo de luto, impotência, onipotência, postura depressiva, vínculos e identidade.

No contexto das teorias psicanalíticas da personalidade, pode-se considerar as identidades ocupacionais como manifestação de processos de sublimação de instintos.

Bohoslavsky escreve (1982):

Possivelmente mais útil do que o conceito de sublimação, seja o de reparação surgido da escola inglesa de psicanálise. Entre nós, Wender postula a hipótese de que as vocações expressam respostas do ego diante dos "chamados" interiores, chamados de objetos internos prejudicados, que pedem, reclamam, exigem, impõem, sugerem, etc., ser reparados pelo ego. A escolha da carreira mostraria a escolha de um objeto interno a ser reparado. Isso significa que a carreira seria uma resposta do ego (invocado) a um objeto interior danificado (invocante).....Possivelmente a reparação seja uma manifestação do instinto de vida, segundo depreende dos textos kleinianos. E é assim, principalmente porque põe fim à destruição, que explicitamente, é manifestação do instinto de morte. A dialética instinto de vida/instinto de morte - traduz-se em condutas polares de destruição reparação (construção). Quando se fala em objeto bom destruído, deve-se esclarecer como se produz essa destruição. Para Melanie Klein a destruição se produz "na fantasia" (S. Isaac), isto é, a destruição do objeto pode ou não ser real. O que destrói o objeto é o ódio, isto é, um derivado do instinto de morte. Quando se fala de um objeto bom destruído, deve-se esclarecer que o objeto bom é objeto de destruição, isto se deve a que além de ser amado, é odiado. Daí concluímos que o vínculo com o mesmo é ambivalente. (p. 73-74).

Abordaremos, a seguir, sobre a questão da reparação. 


\subsection{Reparação}

Continuando o tema da reparação, vejamos o que diz Melanie Klein (1996a):

Ser realmente atencioso implica se colocar no lugar dos outros: nós nos "identificamos" com eles. Essa capacidade de identificação com outra pessoa é um elemento extremamente importante das relações humanas em geral, além de ser uma condição básica para sentimentos de amor fortes e verdadeiros. Só conseguimos deixar de lado ou sacrificar até certo ponto nossos próprios sentimentos e desejos, pondo temporariamente os interesses e emoções do outro em primeiro lugar, se temos a capacidade de nos identificar com a pessoa amada. Se ao nos identificarmos com outras pessoas compartilhamos, por assim dizer, da ajuda ou da satisfação que nós mesmos lhes oferecemos, retomamos de um lado o que perdemos do outro. Em última instância, ao fazer sacrifícios por alguém que amamos e ao nos identificarmos com essa pessoa, desempenhamos o papel de mãe boa ou de pai bom, comportando-nos com ela como nossos pais às vezes se comportaram conosco - ou como gostaríamos que eles tivessem se comportado. Ao mesmo tempo, também desempenhamos o papel da criança boa com os pais, coisa que gostaríamos de ter feito no passado e que agora realizamos no presente. Assim, ao reverter uma situação, ou seja, ao agir com outra pessoa como mãe boa ou pai bom, recriamos e aproveitamos na fantasia o amor e a bondade que tanto desejávamos dos pais. Mas agir como pais bons com outras pessoas também pode ser uma maneira de lidar com as frustrações e sofrimentos do passado. Nossos ressentimentos contra os pais por nos terem frustrado, aliados aos sentimentos de ódio e vingança que estes despertaram em nós, juntamente com os sentimentos de culpa e desespero oriundos desse ódio e dessa vontade de vingança, que nos dão a impressão de ter ferido os pais que ao mesmo tempo amávamos - tudo isso podemos desfazer em retrospecto na fantasia (afastando alguns dos motivos de ódio), desempenhando simultaneamente o papel de pais e filhos amorosos. Ao mesmo tempo, em nossa fantasia inconsciente compensamos os danos que fizemos em fantasia, e pelos 
quais ainda nos sentimos culpados, inconscientemente. Em minha opinião, esse ato de fazer reparação é um elemento fundamental do amor e de todas as relações humanas; assim, irei me referir muitas vezes a ele no decorrer deste trabalho. (p. 352-354)

Da mesma maneira que Melanie Klein fala sobre trabalho de reparação, Bohoslavsky (1982) também coloca ser mais útil do que o conceito de sublimação, o de reparação, pois a escolha da profissão mostraria a escolha do objeto interno a ser reparado; seria a resposta do ego a um objeto interno danificado, ou seja, a pulsão de vida sobrepondo-se à pulsão de morte, colocando fim à destruição do objeto bom em fantasia (podendo também ser em realidade), pois o que destrói o objeto é o ódio, expressão da pulsão de morte e o que o restitui, o recria é a pulsão de vida.

Cabe neste momento esclarecer sobre o uso dos termos sublimação e reparação.

Freud (1924/ 1987) escreve:

A civilização afinal de contas está construída inteiramente sobre a renúncia ao instinto e todo indivíduo, em sua jornada da infância à maturidade, precisa, em sua própria pessoa, recapitular esse desenvolvimento da humanidade a um estado de criteriosa resignação. A psicanálise demonstrou que foram predominantemente, embora não exclusivamente, os impulsos instintuais que sucumbiram a essa supressão cultural. Parte deles, contudo, apresenta a característica valiosa de se permitirem ser desviados de seus objetivos imediatos e colocar assim sua energia à disposição do desenvolvimento cultural, sob a forma de tendências "sublimadas". Outra parte, porém, persiste no inconsciente como desejos insatisfeitos e pressiona por alguma satisfação, ainda que deformada. (p. 257)

Hinshelwood (1992) escreve:

A sublimação é a conversão de impulsos libidinais em habilidades refinadas e criativas. A reparação, por outro lado, não é vista desta 
maneira. De modo característico, Klein ficou interessada no conteúdo psicológico do processo de conversão a que Freud estava se referindo. A reparação está certamente relacionada com os impulsos, mas consiste na fantasia de corrigir os efeitos dos componentes agressivos. Existe alguma sugestão também de que Klein via a reparação como uma fantasia trazida à tona, de modo particular pela agressão, enquanto que a ênfase da sublimação repousa nos componentes libidinais ou sexuais. Entretanto, era importante para ela apontar a interação existente entre os impulsos agressivos e os impulsos libidinais: "O curso do desenvolvimento libidinal é assim, em todos os passos, estimulado e reforçado pelo impulso à reparação e, em última análise, pelo sentimento de culpa" (Klein, 1945, p. 410). A reparação é o resultado da confluência das noções pulsionais opostas, antes que meramente o deslocamento de um impulso para algum representante socialmente aceitável, tal como acontece na sublimação. Mais tarde, quando Klein relaxou o seu comprometimento com a teoria clássica, a idéia de sublimação desapareceu um pouco, enquanto que a idéia de reparação se desenvolveu e tornou-se a pedra angular dos processos de maturação que forjam um caminho de saída para a posição depressiva. (p. 458)

A escolha profissional vai buscar a reparação dos objetos danificados em fantasia; a autêntica reparação que supõe comportamentos reparatórios, requer a clareza quanto ao papel profissional e tem por objetivo contribuir para definir progressivamente a identidade ocupacional daquele que escolhe.

Esse movimento está ligado à angústia e à culpabilidade que é característica da posição depressiva; é um mecanismo pelo qual o indivíduo procura reparar os efeitos provocados no seu objeto de amor pelas suas fantasias de destruição e, isso ocorre em resposta à angústia e culpabilidade inerentes à posição depressiva onde o indivíduo tenta manter ou restabelecer a integridade com relação ao corpo materno; quando a excessiva severidade do superego diminui, emergem sentimentos de culpa que provocam fortes tendências reparatórias. 
O conteúdo individual e os detalhes das fantasias destruidoras ajudam a determinar o desenvolvimento das sublimações que, indiretamente, favorecem as tendências restitutivas, ou servem para produzir desejos ainda mais diretos de ajudar a outras pessoas.

Espera-se que o indivíduo tenha a possibilidade de promover reparações autênticas, levando-se em consideração a realidade do ambiente e suas próprias limitações; que o indivíduo se realize à medida que atenda as suas vocações, que seu ego possa expressar respostas frente aos chamados interiores de objetos atacados que clamam por reparação.

Agindo assim o indivíduo busca uma profissão, na realidade busca um reencontro, tentando restituir e reencontrar o objeto que imaginara ter destruído.

Como a gratidão é o sentimento mais sublime que um ser humano pode ter e expressar, sem dúvida ela é uma expressão da capacidade de amar; segundo a teoria kleiniana essa experiência torna possível a gratidão no nível mais profundo e desempenha papel importante na capacidade de efetivar reparação e em todas as sublimações.

Uma vez que a reparação nunca é total, pois na realidade isso não é possível, ela é parcialmente feita; uma reparação integral restituiria por completo o objeto que em fantasia foi vivido como destruído, correspondendo a uma fantasia onipotente e nesses moldes não se trataria de uma reparação autêntica, na acepção da palavra, mas de uma pseudo-reparação.

Esses objetos internos prejudicados que reclamam serem reparados pelo ego os fazem para preservação da vida psíquica, esperando-se com isso, um indício de capacidade para o indivíduo optar por uma profissão verdadeiramente reparatória, o que corresponderia a uma escolha que em seu sentido subjetivo, se apoiaria numa relação autêntica e não defensiva pela profissão escolhida; para que isso ocorra, o ego necessita estar fortalecido, em condições de tolerar as ambivalências, frustrações, limites, se utilizando da repressão para agüentar tudo isso e não usar dos mecanismos de cisão e de projeção em excesso, pois é justamente isso que acaba debilitando a sua força. 
Também existe a possibilidade das reparações não serem autênticas e sim, pseudoreparatórias, que mostra uma fraqueza egóica, devido ao aprisionamento desse ego a conflitos ligados às primeiras relações objetais, atrapalhando assim sua capacidade de realizar uma escolha de modo mais livre.

Uma criança que está constantemente cerceada pelos pais, aprisionada em seus narcisismos, idealizada, fica sem condições de perceber a realidade à sua volta, acaba ficando enfraquecida e não alicerçada para enfrentar as adversidades da vida, pois vive no Princípio do Prazer e não no Princípio de Realidade.

Quanto mais o ego é deixado dentro do Princípio do Prazer, maior será a dificuldade em submeter-se ao Princípio de Realidade, pois a frustração é um sentimento muito difícil de ser administrado; ao invés de haver um fortalecimento, há um enfraquecimento de suas funções, condições e capacidade, não se desenvolvendo e sim se utilizando da energia pulsional para manter suas defesas, principalmente a dissociação e a negação.

Em que condições um ego frágil e aprisionado em seu desenvolvimento poderá reparar autenticamente seus objetos internos destruídos? É compreensível que seu recurso será utilizar-se da pseudo-reparação, que inevitavelmente, afetará tanto sua identidade pessoal, quanto sua identidade profissional.

Segundo Bohoslavsky (1982), existem duas qualidades básicas de reparação: uma reparação autêntica e uma reparação maníaca.

A reparação autêntica revela um ego que percebe e aceita a realidade, tolera sua ambivalência e consegue realizar tentativas reparatórias (desenvolvendo comportamentos na fantasia e na realidade que procuram reconstruir o objeto danificado); suporta a ansiedade depressiva gerada pela perda, a causa da própria agressão ao objeto bom, do qual depende a capacidade de recriar, tolera a dor, faz-se responsável por seu ódio a respeito do objeto que simultaneamente era amado e reconhece a culpa.

A reparação maníaca apresenta a tríade do comportamento maníaco: desprezo, controle e triunfo, cada um desses sentimentos implica alguma negação da relação com o objeto, 
por isso quando o desprezo, o controle e o triunfo estão presentes nas tentativas reparatórias, contaminando-as, nega-se a culpa. Através do desprezo, negam-se os aspectos bons do objeto; mediante o triunfo, nega-se a perda do objeto e os sentimentos de abandono relativos a ele e pelo controle, nega-se a autonomia do objeto.

Ainda de acordo com o autor acima, além das reparações autêntica e maníaca, pode-se acrescentar outros tipos de reparação, segundo suas formas, são elas: a reparação compulsiva e a reparação melancólica.

A reparação compulsiva ocorre quando a culpa persecutória, suscitada pela destruição do objeto na fantasia é tal que impõe ao ego, atividades sumamente exigentes; o ego funciona de um modo hipermoral, rígido, autoritário, realizando comportamentos que, em lugar de reparar objetos na fantasia, danificam-nos cada vez mais, ou pode chegar a danificá-los cada vez mais, restringindo a autonomia do sujeito; já a reparação melancólica se caracteriza por possuir matizes autodestrutivas como se a única maneira de reparar o objeto fosse destruindo-se a si mesmo; ao se atacar e eventualmente, destruir-se o ego, está se atacando o objeto com que o ego se identificou, ao invés de repará-lo.

\subsection{A Identidade Profissional do Psicólogo}

Encontramos como referência o trabalho de Ryan e Chan (1999) ${ }^{3}$ desenvolvido nos Estados Unidos; trata-se de um artigo que fala a respeito de uma escala - EPPP (Examination for Professional Practice in Psychology), onde os autores discutem que um elo comum dos psicólogos licenciados é a questão do Exame da Prática Profissional em Psicologia (EPPP) e como os examinandos se sentem sobre o EPPP para entrar na profissão de psicólogo. As percepções de como esses examinandos se sentem são discutidas; a informação apresentada foi de uma amostra limitada do EPPP de todos os examinandos, entretanto essa amostra foi representativa de vários modos. As medidas

\footnotetext{
3 "Perceptions of the EPPP: How Do Licensure Candidates View the Process?"
} 
usadas foram adequadas, mas não proeminentemente confiáveis e seu uso em outras situações forneceram limitada evidência de validade. A despeito dessas limitações, os autores sentiram que esse projeto teve algumas implicações interessantes. Aqueles psicólogos que precisavam da licença para a prática viram o EPPP como um processo humilhante, comentário não infrequente nessa amostra; sentiram ligeiras percepções negativas do exame tendo conseqüências indesejáveis para o profissional e sugestões para criar mais percepções positivas foram fornecidas. Os autores não defenderam necessariamente a licenciatura especial, mas um olhar mais próximo à autorização na entrada dos processos para a profissão de psicólogo.

Em sua dissertação de mestrado, Tescarolli (1999) nos leva a conhecer alguns aspectos a respeito da identidade do psicólogo professor universitário e clínico, procurando compreender como esse individuo representa esses aspectos no meio social em que está inserido. Procurou também investigar a capacidade desse profissional de estar continuamente ampliando sua visão da realidade, conforme as demandas recorrentes e como trabalha com essas novas demandas. Foi constatado que é uma categoria profissional com muitas contradições e ambivalências, sentindo-se diferenciada, superior às outras e com uma atuação prática muito pouco voltada para problemas sociais.

Em sua tese de doutorado Voltolini (1999) trata psicanaliticamente a questão da vocação, não com a finalidade de estabelecer sobre ela uma prática clínica especializada, mas a partir de uma injunção social precisa que a fez figurar tal como hoje se conhece: como dúvida pessoal, crise psíquica, liberdade/cobrança de escolha. Inscrevendo-se na direção de pesquisa, aberta por Freud e seguida por Lacan, que articula inconsciente e história, trabalha com a questão da vocação como um "sintoma social", noção essa que permite articular como a constituição singular de cada sujeito se encontra intrinsicamente ligada ao discurso social em relação ao qual está assujeitado. Um exame da bibliografia referente ao tema da vocação mostrou que sua teorização aparece originalmente ligada às práticas orientadoras que sobre ela se montaram, destacando-se a "estratégia clínica" de Bohoslavsky. Examinou-se tal estratégia para ver como aí se dava a fusão entre os campos da Psicologia e da Psicanálise; tal exame revelou que a fusão proposta, só pôde se dar com a descaracterização da Psicanálise; 
assim sendo coube tratar a vocação como um sintoma, único modo de abordá-la de maneira que respeitasse a ética psicanalítica: "responder pelo sintoma".

Bock (1999), num artigo publicado decorrente de uma palestra conferida no Rio Grande do Norte diz:

E, para terminar minha reflexão, trago a questão da identidade profissional do psicólogo. Tenho resistido um pouco a discussões sobre a identidade da Psicologia, porque, em geral, essas discussões buscam uma cara para a Psicologia pensando em poder mantê-la, depois de encontrada. Quero uma Psicologia que se metamorfoseie o tempo todo, acompanhando as mudanças da realidade social de nosso país. Não podemos querer uma Psicologia que seja a cristalização de uma mesmice de nós mesmos. Se entendermos que a identidade é movimento, é metamorfose, devemos entender que a identidade profissional nunca estará pronta; nunca terá uma definição. Estará sempre acompanhando o movimento da realidade. Na verdade, penso que nos enganamos quando falamos que não temos identidade profissional. Temos sim. Temos uma identidade profissional que reflete a prática importante que temos tido, porém, elitista, restrita, pouco diversificada e colocada às necessidades e demandas de setores dominantes de nossa sociedade. Uma minoria que, possuindo condições de comprar nossos serviços, foi por muito tempo a única usuária. Queremos agora dar a volta por cima e construir uma profissão identificada com as necessidades da maioria da população brasileira, uma maioria que sofre, dadas as condições de vida que possui; uma maioria que luta, dadas as condições de vida que possui. Identificar-se com as necessidades de nosso povo e acompanhar o movimento destas necessidades, sendo capazes de construirmos, sempre e permanentemente, respostas técnicas e científicas. É esse o nosso desafio. Queremos estar em busca permanente, em movimento sempre. Queremos que o movimento seja a nossa identidade e que a inquietação seja nosso lema. (p. 328)

Coelho Jr. (1997), nos Cadernos de Subjetividade escreve: 
Diante de oposições como identidade e diferença, não se trata nem de escolher um dos pólos nem de buscar uma síntese que ultrapasse a oposição. Assim sugiro que seja preciso conviver com esta tensão permanente entre identidade e diferença. Deste ponto de vista me parece igualmente inadequado postular tanto a possibilidade de uma verdadeira identidade como afirmar que só existem as diferenças e a multiplicidade. Penso, portanto, a identidade em crise como a descrição possível de um movimento constante que se estabelece a partir da tensão entre polaridades. Identidade em crise não é síntese, nem uma noção que possa ser tomada como uma nova entidade. É a descrição de uma tensão e, por isso, aqui crise não tem sentido negativo, ao contrário, carrega em si uma postura dinâmica afirmativa. Não se deve lamentar uma identidade em crise, mas sim afirmá-la. Crise só surge como algo negativo se se privilegia exclusivamente a noção de uma unidade permanente, imutável da identidade. Crise aqui é sinônimo de tensão criativa, de tensão produtiva. Penso que os processos criativos e críticos só são possíveis por meio do permanente confronto com a tensão que existe entre os pólos da identidade e da diferença da multiplicidade e da unidade. $\mathrm{Na}$ identidade em crise há simultaneidade de identidade e diferença de unidade e multiplicidade. Desta perspectiva não se trata de propor uma identidade que acolha a alteridade, mas sim de firmar uma identidade em crise, que é simultaneamente identidade e alteridade, identidade e diferença, unidade e multiplicidade.

Com estas considerações não espero ter respondido de forma direta qual deve ser a identidade do psicólogo contemporâneo, muito menos ter solucionado o complexo problema ético com o qual se defronta as práticas psicológicas contemporâneas. Mas espero sim ter contribuído pra recolocar o tema da identidade no campo predominante da discussão das diferenças. Identidade em crise e não identidade ou diferença. Identidade em crise e não singularidade, noção que tende a desconsiderar o que há de comum, de semelhante entre diferentes subjetividades. (p. 311-312)

Até aqui temos visto que existem tantos pontos comuns, como pontos divergentes que vão levar um jovem a "escolher" a profissão de psicólogo; Tescarolli coloca ter 
observado a categoria profissional com muitas contradições e ambivalências, categoria esta sentindo-se diferenciada, superior as outras com uma atuação prática pouco voltada para problemas sociais; Voltorini coloca se tratar a vocação como sintoma, ou seja, uma manifestação de conflito que teve que passar pelo recalque e manifestar-se através da formação de compromisso; Bock diz querer uma Psicologia que se metamorfoseie o tempo todo, acompanhando as mudanças da realidade social de nosso país e que uma identidade profissional nunca estará pronta, nunca terá uma definição; tanto ela, quanto Tescarolli, enfocam a questão voltada aos aspectos sociais; Coelho Jr. sugere que se deveria conviver com a tensão permanente entre identidade e diferença, tensão essa criativa, produtiva e não negativa e desta perspectiva não se tratar de propor uma identidade que acolha a alteridade, mas sim de se firmar uma identidade em crise que é simultaneamente identidade e alteridade, identidade e diferença, unidade e multiplicidade; neste posicionamento podemos correlacionar tais simultaneidades aos conteúdos consciente e inconsciente do ser humano, uma vez que todos nós passamos por vivências emocionais acrescidas por nosso "colorido" pessoal, que vão deixando marcas, registros em nossa mente, tecendo nosso histórico de vida; consciente e inconsciente caminhando simultaneamente.

É inegável que existam histórias que são comuns a todos nós, a humanidade, tão bem mostrada e fundamentada por Freud; estou me referindo aos mitos, que por definição segundo o Dicionário Aurélio, do ponto de vista antropológico, significa narrativa de significação simbólica, transmitida de geração em geração e considerada verdadeira ou autêntica dentro de um grupo, tendo geralmente a forma de um relato sobre a origem de determinado fenômeno, instituição, etc., e pelo qual se formula uma explicação da ordem natural e social e de aspectos da condição humana.

Estou me referindo ao Mito de Édipo, que teve em sua história um percurso que nos mostra tão bem a questão do nosso "destino", destino esse a quem ninguém escapa. 


\section{CAPÍTULO 4}

\subsection{Mito de Édipo ${ }^{4}$ e a Escolha Profissional}

Assim como Édipo teve uma história a ser percorrida para chegar a seu destino, assim também a escolha profissional tem um caminho a ser percorrido por nós para que cheguemos aos nossos destinos.

Édipo não é um determinado indivíduo, com um determinado caráter e um destino excepcionalmente trágico, ele é um indivíduo que resolve trilhar um caminho que o levará ao autoconhecimento, mas sem saber disso.

Quando “optamos” pela profissão de psicólogo, embora tenhamos também trilhado um caminho até chegar lá, não temos consciência a nível latente do que nos levou a essa escolha.

Nós, assim como Édipo, temos a pretensão de nos encontrar e com isso, encontrar nossa "verdade", pois ele acaba sendo nosso espelho e quando compreendemos que nele vemos a nós mesmos refletidos, pode acontecer que não só fiquemos gratificados, como também desalentados e frustrados.

Não nascemos desprovidos, nascemos com o nosso "destino" e com ele uma tarefa...

Os homens da antigüidade tinham consciência de que o destino não nasce do acaso, mas da necessidade. A tragédia de Édipo não conta exatamente a história de um homem que matou seu pai por engano; se ela conta a história do homem, isso significa que todo homem mata seu pai e isso está predeterminado em sua vida, ou seja, quando escolhemos essa profissão não é por acaso, há algo que nos leva, nos "predetermina" a

\footnotetext{
${ }^{4}$ Neste capítulo, toda referência ao Mito de Édipo, baseou-se em: DETHLEFSEN, T. Édipo o solucionador de enigmas. São Paulo: Cultrix, 1990.
} 
tal "escolha", onde a fronteira da consciência tem que transformar a visão exterior numa contemplação interior.

Durante algum tempo Édipo vive em Corinto com seus pais adotivos; chega aos seus ouvidos a notícia de que ele não era filho legítimo de Pólipo e Mérope, então ele vai consultar o oráculo de Delfos com a esperança de que este lhe dissesse a verdade sobre sua origem, mas tal como Édipo suspeitava, o oráculo não respondeu à sua pergunta, porém o ameaçou com uma terrível previsão: ele se tornaria o assassino de seu pai e o marido de sua mãe.

Para escapar de qualquer modo a esse destino, Édipo não voltou mais para casa, tomando outro rumo; finalmente chegou a uma encruzilhada e foi então que teve que decidir que rumo tomar, escolhendo uma das três vias e por força do destino, escolheu o caminho que o fez encontrar Laio, seu pai.

Quando vamos deixando a infância e entrando na adolescência, gradativamente nosso modo de encarar os fatos, bem como as compreensões dos mesmos vão se modificando, não apenas pela maturidade, mas também pelas resignificações que vamos fazendo no decorrer da vida e isso nos faz encarar nossos pais de modo diferente, havendo questionamentos e consequentemente, certo distanciamento dos mesmos.

Esse é o momento em que vamos verificar se o que nossos pais nos disseram e nos mostraram, é verdadeiro, tem lastro ou não, muitas vezes recorrendo a amigos ou pessoas mais velhas que possam nos dizer algo, assim como o oráculo de Delfos o fez à Édipo.

Aqui também podemos traçar um paralelo com a questão da busca da orientação profissional funcionando como um "oráculo", objetivando nos revelar que caminho trilhar em tal escolha; caso não tenhamos claro isso, podemos "escolher" o caminho baseado nas idealizações e narcisismos de nossos pais, onde posteriormente haverá um inevitável confronto entre o que eles almejaram e o que realmente "escolhemos".

Como sabemos, Édipo seguiu viagem rumo a Tebas, que estava ameaçada pela Esfinge; tratava-se de um monstro com corpo de leão e cabeça humana, que tomava conta da 
cidade e exigia que os tebanos resolvessem um enigma: enquanto estes não decifrassem o problema, tinham que sacrificar-lhe diariamente um jovem; foi dessa maneira que morreu o filho de Creonte e como Creonte, após a morte de Laio assumiu a direção de Tebas, mandou anunciar que aquele que dominasse a Esfinge, receberia Jocasta e o reino como prêmio.

O momento de ouvir os caminhos revelados pela orientação profissional é crucial, pois também teremos que decifrar o nosso próprio enigma e estarmos atentos a isso, pois se não conseguirmos, seremos engolidos por nós mesmos.

Aqui também é relevante se falar num processo prévio de análise, onde nos ajuda a uma interiorização, um olhar para dentro de nós mesmos, um ensimesmamento, buscando crescimento, desenvolvimento e insights de muitos aspectos de nossas vidas, entre elas, o da escolha profissional.

Embora possamos decifrar nosso enigma, precisamos ver se foi por conscientização ou algo diferente disso, pois se não foi pela conscientização, poderemos ser premiados com uma admirável e cobiçada recompensa que no decorrer do tempo, vamos nos arrepender amargamente, assim como Édipo por ter derrotado a Esfinge em sua decifração, recebeu a própria mãe como recompensa por tal feito, tendo pago um preço altíssimo por isso.

Os deuses mandaram uma peste sobre o país que foi dizimado e tornado estéril. Depois que toda a sabedoria humana não conseguiu afastar o mal, Édipo enviou seu cunhado Creonte até o oráculo de Delfos afim de buscar o conselho dos deuses.

Ao voltar, este revelou ao povo reunido o que os deuses haviam dito: "a morte de Laio pesava como uma grave dívida de sangue sobre Tebas e enquanto não fosse vingado, não haveria salvação".

Imediatamente Édipo assumiu o papel de advogado desta questão; surpreso pelo fato de ninguém ter encontrado o assassino na ocasião do crime, ele exigiu em altos brados que todos os cidadãos ajudassem na busca, revelando o criminoso e assim que ele fosse descoberto, seria expulso do país. 
Nessa postura Édipo acaba mostrando que quer saber a qualquer custo, o que ele não teve condições de avaliar o que exatamente isso significava quanto a questão das conseqüências, bem como uma escolha profissional feitas nesses moldes pela falta de consciência, pela onipotência e arrogância também nos levará a uma resposta a qualquer custo, sem qualquer avaliação, fechando as portas para uma verdadeira compreensão. A falta de consciência nos deixará cegos, a onipotência encobrirá nossa impotência e a arrogância não nos permitirá sermos humildes.

Na própria arrogância e onipotência de Édipo ele acaba sofrendo as consequiências do que ele próprio promulgou, ou seja, se não tivermos consciência do que estamos nos propondo e assumindo, as consequências reverterão contra nós mesmos.

Édipo mandou buscar o cego Tirésias esperando que sua clarividência pudesse apressar a descoberta da verdade, no entanto Tirésias recusou-se com veemência, no início, a expressar sua opinião. Sob pressão e diante das ameaças de Édipo, finalmente Tirésias disse abertamente que o próprio Édipo era o assassino de Laio e esposo da própria mãe.

Mesmo diante de tal revelação, Édipo ainda tentou negar e só quando o servo que saiu vivo da encruzilhada onde Édipo matou Laio e o mensageiro de Corinto anunciou-lhe a morte de Pólibo, é que ele não teve mais como sustentar sua cegueira e defesas, tendo diante de si sua tragédia potencializada.

Assim como Édipo, nós também na nossa profissão precisamos ultrapassar uma fronteira, isso é, a fronteira da consciência, aquela que transforma a nossa visão exterior numa contemplação interior.

Édipo está na fase de transição do primeiro terço de sua vida para o segundo; ele passou da fase infantil e ingênua e, portanto, do mundo pouco consciente da criança para a fase do desenvolvimento do ego e da conquista desse mundo. No limiar que separa e une essas duas fases, existe sempre a possibilidade de culpa, embora não haja ainda a consciência plena da mesma.

A conscientização da própria culpa introduz a terceira fase da vida: Édipo tem de tornarse, no sentido externo, primeiro um adulto e, para tanto, precisa cortar o cordão 
umbilical que o liga a seus pais externos, o que de fato acontece quando ele os abandona e não volta mais para casa.

No decorrer de nossas vidas vamos sendo conduzidos a nos deparar com a nossa consciência, o que per si é angustiante, nos levando ao sentimento de culpa, entre outros sentimentos, em função de estarmos abdicando a certos fatos em detrimento à outros; vamos deixando de ser crianças para nos tornarmos jovens e depois adultos.

Faz parte da transição da primeira para a segunda fase de nossas vidas, a questão da escolha profissional e ficamos diante de uma encruzilhada fantástica: Qual desses caminhos seguir? Por onde ir? Como fazer tal "escolha?" Sem termos, se quer consciência, o caminho que iremos "optar" não é casual, ele já está determinado por motivações inconscientes e estaremos indo ao encontro de nosso destino, não tendo como escapar dele.

Assim como o oráculo revela aquilo que é, a orientação profissional também faz o mesmo. Se traçarmos um paralelo disso com a análise, veremos que a mesma não muda ninguém, ela irá revelar ao indivíduo aquilo que ele, até então, não pôde ser, mas já estava presente o tempo todo em estado latente.

O momento da "escolha" profissional é o que pressupõe o indivíduo ficar na posição ereta, ter que começar a se sustentar em suas próprias pernas, perdendo então a "estabilidade e segurança" de sua infância; isso significa ter de se decidir, escolher o que lhe faz sentido, do que não lhe faz sentido; viver a desilusão e o luto pela perda de sua condição de criança, perceber que é ele quem tem que se posicionar frente a uma decisão, se deparando com novos conflitos.

Trata-se da fase do apego ao ego, da qual se alimenta a divisão entre ego e não-ego; andar sobre duas pernas pode ser perigoso, há sempre o risco de cair. A vida com um ego é perigosa, pois ela exige a contraparte; a atividade dinâmica é perigosa, pois traz a culpa. 
$\mathrm{Na}$ fase da dualidade, o ser humano vive a ascensão e a queda; nessa fase as contradições visíveis do mundo levam os homens ao mais profundo desespero e nele, eles entendem que foram chamados para unir os opostos, em vez de criar dificuldades.

Édipo entra na fase do conflito ao pisar na encruzilhada e percorre até a cegueira; na medida em que ele deixa de olhar para o mundo exterior, ele aprende a descobrir o mundo em si mesmo e aprende a viver nele.

Ao "escolher" uma profissão, em especial a de psicólogo, temos que deixar de olhar só para o mundo exterior e nos perceber internamente, pois é aí que teremos a possibilidade de ver qual caminho seguir, reconhecendo com isso nossa fraqueza e desamparo.

Quando Édipo se vê diante da revelação de sua história, fica inquieto, pois ao entrar em contato com a verdade, não consegue mais encontrar a paz; ele decide percorrer o caminho do autoconhecimento, partindo em busca da verdade, embora lhe seja muito dolorosa.

É aqui que acontece o retorno que Tirésias provocou, aqui começa a volta de Édipo ao lar, à volta do filho pródigo; a orientação exterior cede lugar a um caminho interior, a descoberta da própria verdade, da própria culpa e acarreta a pergunta: quem de fato sou eu? É aqui que o homem começa a pôr em dúvida a identidade que teve até então, começa a receber de volta as projeções de culpa que foi jogando paulatinamente no ambiente externo e a transformar seus múltiplos conhecimentos em percepção intuitiva.

Aqui também temos o momento de ir atrás de nossa identidade, não só pessoal, mas também vocacional e profissional, identidade essa que vai ser verificada e analisada, onde etapa por etapa nos levará a um crescimento interior.

Embora Tirésias lhe tenha dito tudo logo no início, tudo o que ele precisava saber, Édipo ainda precisava de mais tempo para si mesmo, para aos poucos compreender essa verdade como a sua verdade; de nada lhe adiantou ouvi-la de uma outra pessoa, pois ele precisava, literalmente crescer para isso. 
Vemos em muitas orientações profissionais que embora seja "revelado" o que está latente, muitas vezes acaba não podendo ser entendida e digerida pelo indivíduo, pois falta a condição interna de crescimento para tal compreensão; se a pessoa não se conhece internamente, fica impossibilitada de conhecer o que lhe diz respeito, de sua própria vida.

O homem não está predestinado a modificar o mundo, mas a descobri-lo; é difícil lidar e aceitar isso, pois modificar significa agir e, agir implica um ato voltado para o fora e, portanto, dá apoio às projeções.

A necessidade de descobrir o mundo é muito mais perigosa, pois ela perturba momentaneamente todas as projeções e obriga à percepção, fazendo com que nos tornemos idênticos ao mundo e os problemas do mundo estão dentro de nós.

Descoberta e percepção são, portanto, o objetivo, não a mudança. Édipo não tem de se modificar, ele apenas precisa se descobrir; com essa descoberta, tudo o mais se modifica para ele; é por isso que a tragédia não adota um tom moralista, ela não quer educar o homem através de alguma norma, antes porém, ela lhe revela o seu segredo e o ajuda a descobrir-se, assim como a orientação profissional que vai poder nos revelar o segredo de "optarmos" por ser psicólogos, ajudando-nos a nos descobrir e com isso, trilharmos o caminho do nosso destino.

Tirésias diz ao ir embora:

"Ele vê, mas tornar-se-á cego;

é rico e acabará mendigando;

seus passos o levarão a terra do exílio,

onde tateará o solo com seu bordão."

5 Sófocles; Ésquilo. Rei Édipo, Antígone, Prometeu Acorrentado (tragédias gregas). Rio de Janeiro:

Edições de Ouro, s.d., p. 118. ( Coleção Universidade) 
Isto também se aplica quando nos conscientizamos de nosso "segredo revelado" ao descobri-lo de que, desse momento em diante, estaremos cegos, pobres e apenas com um bordão, teremos que caminhar em nosso exílio e continuar construindo nossa identidade profissional como psicólogos. 


\section{CAPÍtUlO 5}

\subsection{O Uso do TAT (Thematic Apperception Test)}

\section{O Teste de Apercepção Temática - TAT}

Dentre as técnicas de que dispõe o psicólogo para a investigação da personalidade sobressaem-se os métodos projetivos como aqueles que possibilitam uma apreensão profunda de conteúdos dos quais nem sempre o sujeito tem consciência.

A noção de "projeção", quando se fala de técnicas projetivas, não se refere apenas ao mecanismo de defesa, mas também a um processo natural comum a todos os indivíduos, como aponta Bell (1978 apud VAN KOLCK, 1981), trata-se de uma projeção interpretativa.

Iniciaremos com um breve histórico do significado do termo projetivo.

A noção de "projeção", quando se fala de técnicas projetivas não se refere apenas ao mecanismo de defesa, mas também a um processo natural comum a todos os indivíduos.

Bellak (1978a) diz:

O termo "projeção" foi introduzido por Freud já em 1894 em seu trabalho "Neurose de Angústia", onde afirmava: "A psique desenvolve uma neurose de angústia, quando não se sente em condições de realizar a tarefa de controlar a excitação (sexual) que surge endogenamente, quer dizer, atua como se houvera projetado essa excitação no mundo exterior". Em 1896 em seu trabalho "As Neuroses de Defesa" continuou elaborando seu conceito de projeção, mais explicitamente que a projeção é um processo que consiste em 
atribuir aos próprios impulsos, sentimentos e afetos a outras pessoas, ou ao mundo exterior como um processo defensivo que nos permite ignorar esses fenômenos "indesejáveis" em nós mesmos. (p. 25)

Continua Freud (1913 /1987) escrevendo:

Mas a projeção não está especialmente criada com fins de defesa; também surge quando não há conflitos. A projeção de percepções internas ao exterior é um mecanismo primitivo, que por exemplo, influi também sobre nossas percepções sensoriais, de modo que, normalmente desempenha o papel principal da configuração de nosso mundo externo. Sob condições que não estão ainda suficientemente determinadas, incluso as percepções internas de processos ideacionais e emocionais, se projetam no exterior, como percepções sensoriais e são utilizadas para configurar o mundo exterior,quando deveriam permanecer dentro do mundo interno. (p. 86)

Freud descreve com freqüência a projeção como a deformação de um processo normal, que nos leva a procurar no mundo exterior, a causa dos nossos afetos; é desse modo que ele parece conceber a projeção.

A proposição "odeio-o" é transformada por projeção nesta outra "ele me odeia", o que então vai me conceder o direito de o odiar.

Dentro da teoria Kleiniana, o "mau objeto" é projetado como se a pulsão ou afeto para serem verdadeiramente expulsos devessem necessariamente encarnar num objeto; o lactente começa projetando o seu instinto de morte, incrementado pelo trauma do nascimento; posteriormente a projeção é utilizada para atribuir aos objetos externos sentimentos de índole variada, predominantemente amor, medo e ódio. Finalmente, e poderíamos dizer que, a partir do segundo trimestre de vida, pode-se projetar juntos ou separadamente, as percepções, os impulsos, os afetos, as imagens parciais e também determinados aspectos parciais do ego; o mecanismo de projeção serve também para fins de expulsão. 
O termo "projeção", pode ser caracterizado como um processo inconsciente que serve como defesa contra tendências inconscientes, resultando em atribuir ao outro (pessoa ou objeto), impulsos, sentimentos, ideais, atitudes ou aspectos inaceitáveis da personalidade, com a função de manter a homeostase psíquica, ou seja, atribuir algo do mundo externo, significa deslocar de "dentro" para "fora" e em conseqüência ver aquilo que está "dentro", como estando "fora".

A propósito dos testes projetivos, esses demonstram que não se trata apenas de estruturação de estímulos em correspondência com a estrutura da personalidade; o indivíduo projeta aquilo que é, que gostaria de ser e também aquilo que recusa ser, onde o conceito de projeção não aparece apenas como função defensiva, mas também como função expressiva, estando esta última fundamentada na tendência natural do homem em ver o mundo à sua própria imagem.

Segundo Anzieu (1978), podemos conceber o teste projetivo como um raio X; atravessando o interior da personalidade, fixando a imagem do seu núcleo secreto sobre um revelador (aplicação do teste), permitindo depois sua leitura, por meio da ampliação ou projeção ampliadora em uma tela (interpretação do protocolo). O que está escondido fica assim iluminado; o latente se torna manifesto; o interior é trazido à superfície; o que há em nós de estável e também emaranhado, é desvendado.

Há uma interação dinâmica entre os objetos do mundo externo e do mundo interno da pessoa, criando-se uma terceira realidade; a esta percepção dinâmica significativa da realidade Bellak (1978a) propõe o termo "apercepção", de acordo com essa definição, a apreensão dos dados do mundo externo terá sempre um componente subjetivo.

Quanto às técnicas projetivas, o que as caracteriza se refere à falta de estruturação e sua eficácia para indicar a configuração psicológica do sujeito, através de seus esforços espontâneos para "estruturar" o material da prova.

A técnica projetiva supõe a existência de aspectos não conscientes da personalidade; os materiais da prova e as instruções são perguntas indiretas, representadas pelas 
ações/reações do sujeito, sobre aqueles aspectos da sua estrutura psicológica, das quais não tem consciência e é incapaz, portanto, de comunicar diretamente .

O que se procura nas técnicas projetivas é justamente favorecer ao máximo o aparecimento do mundo interno da pessoa. É fornecido um mínimo de elementos externos, suficientes apenas para eliciar a resposta e permitir uma avaliação do contato com a realidade.

Os estímulos que constituem o material das técnicas projetivas devem ser pouco estruturados, o que impede que o indivíduo se apóie em informações convencionais e favorece o aparecimento dos fatores internos.

Isto se aplica tanto ao material em si (pranchas, palavras isoladas, materiais diversos) como às instruções as quais propiciam a liberdade no uso do material apresentado, evitando a indução ou direcionamento da resposta ("complete a frase", "conte uma história"... "desenhe uma pessoa....". Segundo Anzieu (1978), devemos contar ainda com o desconhecimento por parte do sujeito, de como serão interpretadas as respostas, a fim de que este não venha a modificar, consciente e sistematicamente, a essência de suas respostas.

O Teste de Apercepção Temática (TAT) de Henry Murray (1951), faz parte desse conjunto de técnicas. Através do uso de figuras que representam diversas situações frente às quais o sujeito deve criar uma história (daí ser um teste temático), procede-se à exploração da personalidade da pessoa.

Exposto a esse material, a pessoa sem perceber, identifica-se com uma personagem por ela escolhida e, com total liberdade, comunica através de uma história, sua experiência perceptiva, mnêmica, imaginativa e emocional. Desta forma, pode-se conhecer quais situações e relações sugerem ao indivíduo temor, desejos, dificuldades, assim como as necessidades e pressões fundamentais na dinâmica subjacente de sua personalidade (MURRAY, 1951).

Trata-se de um enfoque dinâmico que reconhece elementos estáveis (id, ego, superego, ideal de ego) (HALL; LINDZEY, 1969). 
Cabe aqui um esclarecimento: vamos utilizar apenas a Prancha 1 do TAT, pois não temos como objetivo fazer um diagnóstico dos estudantes e sim entender um pouco mais os conteúdos das respostas, principalmente a nível latente, usando a prancha como um estímulo auxiliar a mais; é uma prancha universal, que pode ser tanto aplicada em homens, quanto em mulheres; é a prancha que abre a aplicação do teste e em geral, não representa uma situação muito ameaçadora. A personagem é uma criança, percebida como distante do próprio sujeito, e a situação é relativamente estruturada. A temática mais freqüente refere-se à relação com a autoridade (pais, professor), atitude frente ao dever e também ideal de ego (capacidade de realização, de atingir objetivos propostos).

Souza (1995) escreve:

"Contar uma estória diante da prancha do TAT é mais um ato de organização do que um ato de imaginação" (Shentoub, in Anzieu, D., 1979). As palavras, ou seja, a estória relatada vêm organizar o que a percepção da prancha despertou. Em outras palavras, o discurso consciente, assim como o conteúdo manifesto de um sonho, é uma forma de apresentar os conteúdos inconscientes despertados pelas pranchas. (p. 141)

Freqüentemente, o discurso reflete, ainda, a atitude do indivíduo frente à situação de teste. Por ser o primeiro estímulo a ser apresentado, dá margem à investigação da capacidade de adaptação do sujeito a uma nova situação, o que vem de encontro com os objetivos propostos para essa pesquisa.

Shentoub (1990, p. 45) na segunda parte de seu livro, descreve a prancha 1 da seguinte maneira:

\section{Prancha 1}

Material manifesto: esta prancha representa um menino, com a cabeça entre as mãos, que olha um violino que esta na sua frente . 
Manifestações latentes: a prancha remete preferencialmente a identificação de um indivíduo jovem, em situação de imaturidade funcional que se encontra frente a um objeto que pode ser considerado um objeto adulto cujos significados simbólicos são transparentes.

A questão que se apresenta é a seguinte: em que medida esta criança cuja imaturidade funcional, reconhecerá o que será necessário para que ele seja "capaz de usar este instrumento?"

Para que a questão possa ser colocada desta maneira, é necessário que a criança e o violino sejam percebidos na sua integridade de um lado a percepção do menino remete a uma representação humana integral, não defeituosa; de outro lado o violino deve ser identificado como um objeto não alcançado na sua integridade, isto é, não quebrado, nem estragado.

Se objeto e criança são percebidos na sua integridade, a hipótese que pode ser emitida mais freqüentemente ( a condição que essa hipótese na seqüência não seja questionada) é que há a capacidade para o sujeito de se situar inteiro frente a um objeto inteiro.

O sujeito pode reconhecer que o menino, no tempo presente, é incapaz de se servir do objeto "violino", interpretação que leva a impotência atual da criança porém poderá ser superada no futuro. $\mathrm{Na}$ melhor das hipóteses, isso implica o reconhecimento da angústia de castração, problemática essencialmente colocada nesta prancha, a saber o reconhecimento da imaturidade atual da criança e a possibilidade dela se desengajar num projeto identificatório (o que corresponde ao tema banal), com um jogo possível entre as posições ativas e ou as posições passivas, considerando a bissexualidade psíquica.

A problemática de castração não deve ser somente entendida em termos de potência/impotência (ter ou não), porém igualmente como a possibilidade de acessar o gozo e o prazer, deveremos então nos interrogar sobre o local do afeto; o objeto "violino" pode ser considerado como objeto de desejo de prazer.

Quando a problemática narcisista e a luta antidepressiva dominam, constata-se uma evitação de angústia de castração na afirmação de uma posição toda poderosa através das estórias de estilo: "É uma 
criança prodígio, ele se vê tocando, numa sala, aclamado por um público fascinado por suas capacidades, etc".

Neste caso, é o princípio do prazer que se afirma sobre um modo megalomaníaco negando a imaturidade funcional da criança e sua impotência atual.

Do lado oposto pode aparecer uma posição inversa (porque a posição megalomaníaca se associa a um profundo sentimento de impotência) nestas histórias de estilo. "É uma criança desesperada, ele nunca chegará a resolver, ele é incapaz de, etc" ,colocando em evidência as insuficiências de investimento: são os afetos depressivos que surgem então.

Não podemos deixar também de citar Leopold Bellak (1978b p.130) em sua descrição da prancha 1, uma vez que dá ênfase a questão das relações com as figuras parentais, onde diz:

\section{Lámina 1}

Esta lámina por lo común lleva a una identificación del examinado con el muchacho y pone de manifiesto la relación con las figuras parentales. Esto es, se hace evidente si el examinado percibió a los padres como agresivos, dominantes, cooperativos o protectores. Aparte de conocer la relación del examinado con sus padres también averiguamos con cuál de ellos existía un determinado tipo de relación. A menudo surgen temas sobre el conflicto entre la autonomia y el sometimiento a la autoridad, en todas sus amplias variaciones y diversas configuraciones. Por ejemplo, un examinado puede tratar desobedecer la orden paterna de practicar el violín jugando en la calle, pero finalmente siente que debe regresar y tocar el violín; o bien puede huir del hogar; o se describe al héroe como un muchacho que no obedece a los padres y hace siempre lo que quiere. Más tarde fracasa porque no los obedeció. Así, un examinado puede exhibir sentimientos de culpa sobre sua autonomía mientras que, en otros casos, el que ha huido del hogar triunfa en la vida. Por lo tanto, esta lámina se utiliza exitosamente, sobre todo con adolescentes. 
Otra necesidad que esta lámina suele ponerde manifiesto es la de logro. Resulta particularmente importante observar cómo se alcanza el éxito, si se da sólo en el nivel de la fantasía o en el de la realidad. Por último, comprobamos que los examinados dan respuestas sexuales simbólicas a esta lámina. El juego con las cuerdas del violín, con el violín mismo, frecuentemente se convierte en una historia simbólica de masturbación, y suelen surgir temores de castración cuando el examinado insiste en que las cuerdas se han roto. Quisiera volver a repetir que es necesario mostrarse sumamente cauteloso para no ver símbolos en todas las historias y sobreestimar su importancia, aun cuando estén acentuados. 


\section{CAPÍTULO 6}

\subsection{A Entrevista Semidirigida}

Optamos por utilizar a entrevista semidirigida uma vez que a mesma permite que o sujeito aja de modo natural, dando-nos a oportunidade de observar a dinâmica de como ele vai se colocando, suas reações, atitudes, bem como nos permitindo interferir a qualquer momento em que algo necessite de aclaramento.

Particularmente preferimos nomear como entrevista ou primeiro encontro, uma vez que essa denominação permite uma maior flexibilidade na operacionalização dos propósitos da mesma.

Segundo Ocampo (1986), a entrevista semidirigida caracteriza-se quando o sujeito tem a liberdade de expor seus problemas começando por onde preferir e incluindo o que desejar, permitindo que o campo psicológico configurado pelo entrevistador e sujeito se estruture em função de vetores assinalados pelo sujeito, embora o entrevistador possa intervir a qualquer momento, para que tenha aclaramentos de coisas que não ficaram claras, ou que mereçam maiores explicações.

Os critérios que se utilizam para a interpretação da entrevista semidirigida incluem o tipo de vínculo que o sujeito estabelece com o entrevistador, a transferência e contratransferência, as ansiedades predominantes, as condutas defensivas utilizadas, entre outros; esses que assinalamos são os que nos interessaram na realização das mesmas.

Para poder se obter isso, deve-se especificar quais são os objetivos a serem atingidos pela entrevista semidirigida: perceber a primeira impressão que nos desperta o sujeito, se a mesma se mantém ou vai se modificando no decorrer do encontro; a verbalização utilizada, se fala de maneira clara ou confusa, a que tempos de sua vida se refere, se fala 
de modo fluente ou não; o nível se ansiedade que manifesta, se vai se diluindo ou se incrementando no decorrer da mesma; se o que fala corresponde com aquilo que está mostrando, ou seja, se naquilo que fala deixa transparecer aquilo que sente; como lida com o rapport que abriu o contato entre ele (sujeito) e entrevistador; o que o sujeito transfere para o entrevistador, no sentido de que papel o entrevistador é colocado pelo sujeito e de que maneira ocorre a contratransferência.

Tudo isso que foi colocado com relação ao sujeito, também é válido para o entrevistador, uma vez que acreditamos num relacionamento recíproco entre dois seres humanos que se reúnem num determinado lugar para realizarem juntos um encontro, formando um par analítico.

Fundamentando o que foi dito acima, citamos que os Baranger (aput Etchegoyen, 2004) colocaram:

Em “A situação analítica como campo dinâmico" (1961/1962), os Baranger definem claramente o que entendem por campo bipessoal da situação analítica e afirmam que é um campo de par que se estrutura sobre a base de uma fantasia inconsciente, a qual não pertence somente ao analisando, mas a ambos. $\mathrm{O}$ analista não pode ser espelho, ainda mais pelo fato de que um espelho não interpreta (1969 p. 140)....Poder-se-ia pensar que a idéia de revèrie de Bion (1962b) apóia o conceito de par analítico. O que Bion postula é uma capacidade de ressonância com o que o paciente projeta, mas isso não tem por que depender de determinados registros e sim de uma capacidade global da personalidade. $\mathrm{O}$ analista recebe mais $\mathrm{O}$ paciente quanto mais revèrie tem; em outras palavras, quanto melhor analista é. (p. 36)

Concordamos com Etchegoyen (2004) quando ele fala que uma norma básica da entrevista, que em boa parte condiciona sua técnica, é a de facilitar ao entrevistado a livre expressão de seus processos mentais, o que nunca se consegue em um enquadramento formal de perguntas e respostas. Como diz Bleger (1971), a relação que se procura estabelecer na entrevista é a de que dá ao sujeito a maior liberdade para se estender, para se mostrar como é. Disso decorre que Bleger sublinhe a grande diferença 
entre interrogatório e entrevista. O interrogatório tem um objetivo simples, obter informação.

A entrevista, ao contrário, pretende ver como funciona um indivíduo e não como diz que funciona. $\mathrm{O}$ que aprendemos com Freud é, justamente, que ninguém pode dar uma informação fidedigna de si mesmo. Se pudesse seria dispensável a entrevista. $\mathrm{O}$ interrogatório quer averiguar o que o entrevistado sabe, o que lhe é consciente. A entrevista psicológica parte de outro pressuposto, quer indagar o que o entrevistado não sabe, de modo que, sem desqualificar o que ele possa dizer-nos, vai nos ilustrar o que possamos observar no curso da interação promovida pela entrevista.

Foi Sullivan (1944/1945) o criador da teoria da entrevista, que criou a expressão de observador participante, a que Etchegoyen (2004) fala:

\footnotetext{
Entendo por observador participante aquele que mantém uma atitude que o faz ser reconhecido no campo como um interlocutor que não propõe temas, nem faz sugestões, e frente ao qual o entrevistado deve reagir sem que lhe seja dado outro estímulo a não ser o da presença, nem outra intenção senão a de levar adiante a tarefa. Em resumo, o entrevistador participa e condiciona o fenômeno que observa e, como diz Bleger, com sua precisão característica, 'a máxima objetividade que podemos obter só é alcançada quando se incorpora o sujeito observador como uma das variáveis do campo'. (p. 19)
}

Não perdemos de vista que o encontro se faz entre duas pessoas e que portanto, fica sem sentido pensar que uma terá o papel e função de entrevistador, enquanto a outra se submeterá a esse papel e função; que o entrevistador por estar numa situação privilegiada de "comando", será "neutro e asséptico" em sua postura, para que seja o mais imparcial possível, "apenas" estando no encontro para atingir seus objetivos de pesquisa, limitando-se a ouvir, estimular o sujeito a responder ao que quer saber, anotar as respostas, solicitar esclarecimentos e ponto. Essa postura parte de um pressuposto mecanicista, positivista e compartilhamos de uma outra postura, onde num encontro humano, acima de tudo, o "humano" será privilegiado e inserido no contexto e não, eliminado do mesmo. 
Pudemos observar que justamente o envolvimento entre entrevistador e sujeito foi o que proporcionou que a pesquisa pudesse ter sido feita, pois tal envolvimento é inevitável numa relação humana; num trabalho a dois deve haver parceria, compartilhamento e isto requer envolvimento, tendo-se claro os limites desse envolvimento, não se perdendo de vista o propósito e objetivo do trabalho de pesquisa. Dizendo em outras palavras, deve haver um envolvimento, desde que fique claro que é um envolvimento a nível profissional e não pessoal e íntimo.

Se tal envolvimento não ocorrer, como fica então a questão da empatia? Sabemos que num relacionamento profissional, caso não ocorra a empatia, situação sine qua non para que possa haver um campo transferencial onde os fenômenos mentais possam se manifestar, vai acontecer exatamente o contrário, ou seja, a antipatia, estabelecendo-se com isso uma transferência negativa, resistência, onde no caso de uma pesquisa, o pesquisador fica impossibilitado de agir.

Bleger (1970) vai colocar que a interdependência e inter-relação, o condicionamento recíproco de suas respectivas condutas, se realiza através do processo de comunicação, entendendo-se por isso o fato de que a conduta de um, consciente ou não, atua de forma intencional ou não, como estímulo para a conduta do outro, e por sua vez esta última reatua como estímulo para as manifestações do primeiro, onde neste processo a palavra tem um papel de enorme gravitação, no entanto também a comunicação pré-verbal intervém ativamente através das atitudes, timbre e tonalidade afetiva da voz, etc.

Concordamos com Thiollent (1986 apud RIBEIRO, 1991) quando escreve:

As exigências são diferentes daquelas que são comumente aceitas de acordo com o padrão convencional de observação, total substituibilidade dos pesquisadores e quantificação da informação colhida na observação, enquanto princípios de objetividade. (...) Sem abandonarmos o espírito científico, podemos conceber dispositivos de pesquisa com base empírica nos quais, em vez de separação, haja um tipo de co-participação dos pesquisadores e das pessoas implicadas no problema investigado". E ainda, "a condição de 
objetividade pode ser parcialmente respeitada por meio de um controle metodológico do processo investigativo". (p. 32) 


\section{CAPÍTULO 7}

\subsection{Método}

Esta é uma pesquisa qualitativa em que foram utilizados os relatos verbais de 21 estudantes do primeiro e segundo anos de Psicologia que se prontificaram a participar da mesma, sem que se tivesse qualquer pretensão para uma quantidade pré-estabelecida de participantes e quanto à questão do sexo dos mesmos. Nas duas classes do IPUSP em que pude falar sobre minha pesquisa, haviam aproximadamente 70 alunos, sendo que dessa instituição 14 se interessaram a participar, os 7 outros alunos foram de faculdades particulares.

Foram utilizados dois instrumentos para a coleta de dados: a Prancha 1 do TAT como instrumento auxiliar na coleta de dados, objetivando entender sobre as motivações inconscientes relacionadas à escolha profissional desses estudantes, uma vez que essa prancha tem como tema mais freqüente a questão da relação com a autoridade, atitude frente ao dever e também ao ideal de ego, no que se refere à capacidade de realização e de se atingir objetivos propostos e um modelo de Entrevista Semidirigida baseada em um roteiro com o objetivo de obter dados manifestos, conscientes que interessavam ao pesquisador, dados esses relacionados ao que os levou a procurar Psicologia, à história de vida, estrutura familiar, semelhanças e identificações com os modelos parentais, formação dos irmãos, caso tivessem, conhecimentos a respeito das áreas em que a Psicologia atua, se corresponderam ou não às expectativas dos pais, tipos de reparação, na tentativa de se fazer uma correlação com a escolha pela profissão de psicólogo.

Optamos por fazer primeiro o TAT e posteriormente a Entrevista Semidirigida, porque queríamos estar livres de todas as interferências possíveis, uma vez que a estória contada na prancha remete ao conteúdo latente, inconsciente; já a Entrevista Semidirigida as perguntas foram feitas a nível manifesto, consciente. 
Os registros das respostas foram transcritos de modo fidedigno ao que foi falado e a avaliação foi feita seguindo-se:

01. A análise de conteúdo no que se refere ao tema, identificação e necessidades do herói, figuras, objetos ou circunstâncias introduzidas, omitidas ou distorcidas, concepção do ambiente, figuras percebidas como..., reação do herói, conflitos significativos, ansiedade, adequação do superego e integração do ego;

02. A análise formal no que se refere ao tempo, comportamentos, elementos de linguagem e estruturação do tema.

Utilizou-se como critério de inclusão a questão dos estudantes não conhecerem o teste TAT; inicialmente foi pensado aplicar esse instrumento em alunos de Psicologia em geral, de primeiro ao quinto ano, mas depois ficou decidido ficar restrito a alunos de primeiro e segundo anos, tentando evitar assim a possibilidade de um conhecimento prévio do teste TAT, uma variável a menos para ser controlada e que pudesse, de alguma forma, levar a um desvio dos resultados, embora tenhamos claro que mesmo uma pessoa tendo conhecimento do teste, ela acaba projetando conteúdos inconscientes, uma vez que não se tem como controlar os conteúdos advindos do inconsciente.

"Quem tem olhos para ver e ouvidos para ouvir, convence-se de que os mortais não conseguem guardar segredos. Se os lábios estão mudos, eles tagarelam com as pontas dos dedos; a traição força seu caminho por todos os poros" (FREUD, (1905/1987, grifo nosso) ${ }^{6}$

A aplicação foi feita individualmente pelo mesmo aplicador, objetivando-se que outras variáveis intervissem na coleta dos dados e que isso pudesse de alguma forma alterar a análise dos mesmos; após o estabelecimento do rapport, houve a explicação sobre os objetivos da pesquisa, instruções de como se daria a investigação e assinatura de um Termo de Consentimento.

\footnotetext{
${ }^{6}$ Freud, S. (1905, apud Gay, 1989), p. 16-17
} 


\section{CAPÍTULO 8}

\section{1 Apresentação e Análise dos Resultados}

Vamos iniciar a apresentação e análise dos resultados pelas respostas dadas na Prancha 1 do TAT, uma vez que demos início ao processo de coleta de dados pela mesma.

Mediante a análise das percepções do estímulo da Prancha 1 visualizada pelos alunos, encontramos cinco tipos de respostas que foram: percepção do violino, violão, instrumento musical, percepção distorcida do estímulo e não percepção do estímulo.

Para melhor visualização dos resultados obtidos, colocaremos os mesmo sob forma de tabelas.

Percepção da Prancha 1 do TAT - Relação da percepção Objetivo-Estímulo - grau de projeção, deformação ou negação do estímulo

\begin{tabular}{|c|c|c|}
\hline Respostas & $\mathrm{N}^{\mathrm{o}}$. de Alunos & Porcentagem \% \\
\hline Percepção do violino & 12 & 57,15 \\
\hline Violão & 02 & 9,52 \\
\hline Instrumento Musical & 01 & 4,76 \\
\hline $\begin{array}{c}\text { Percepção distorcida do } \\
\text { estímulo }\end{array}$ & 02 & 9,52 \\
\hline Não percepção do estímulo & 04 & 19,05 \\
\hline Total & 21 & 100,00 \\
\hline
\end{tabular}

TABELA 1 - Percepção da Prancha 1 do TAT - Relação da percepção Objetivo-Estímulo - grau de projeção, deformação ou negação do estímulo 
Como é do nosso conhecimento, a Prancha 1 do TAT propicia a projeção dos desejos inconscientes, muitas vezes recalcados daquilo que precisa ficar oculto, escondido da censura. A partir disso, podemos analisar o que esta projeção desencadeou nos alunos, se houve projeção maciça ou não, o tipo de projeção e se as defesas se sustentaram.

No relato feito nas estórias houve a presença da razão e da racionalização que aponta para uma defesa intelectual para encobrir o latente; a necessidade de encobrir o latente se deve a algo que não pôde aparecer de modo claro, ou seja, denuncia o desejo que precisa ficar subjugado à censura.

Isso equivale ao funcionamento dos processos dos sonhos discutido por Freud, precisando haver uma deformação pela formação de compromisso $^{7}$, ou seja, o desejo recalcado sai, só que disfarçado.

Dando continuidade, a Entrevista Semidirigida por propiciar verbalizações mais a nível racional veio complementar a análise das percepções feitas pelos alunos. A primeira pergunta feita foi “O que o(a) levou a fazer Psicologia?" é uma pergunta que o aluno responde no racional, no manifesto; equivale a dizer "Por que você escolheu Psicologia" e a resposta "Porque eu....". Se a pergunta é direcionada ao racional, a resposta será inevitavelmente no racional também e com isso temos a possibilidade de observar a presença das defesas que acompanham as mesmas.

Nossa investigação vai ao encontro de perceber a racionalização como mecanismo de defesa, como ela se mantém e a influência da mesma na escolha objetal, ou seja, em que moldes a "escolha" pelo curso de Psicologia foi feita.

Pelo aporte kleiniano temos a correlação entre as relações objetais, angústia e defesa, sendo que iremos correlacionar isso com as respostas dadas pelos alunos diante da

\footnotetext{
${ }^{7}$ Forma que o recalcado vai buscar para ser admitido no consciente, retornando no sintoma, no sonho, e, mais geralmente em qualquer produção do inconsciente: as representações recalcadas são então deformadas pela defesa ao ponto de serem irreconhecíveis. Na mesma formação podem assim satisfazerse - num mesmo compromisso - simultaneamente o desejo inconsciente e as exigências defensivas.

(LAPLANCHE; PONTALIS, 1988)
} 
Prancha 1 do TAT e da Entrevista Semidirigida, que angústias foram geradas e quais defesas desencadeadas.

Passamos agora a analisar a relação da percepção objeto-estímulo - Tabela 1 demonstrada pelos alunos através das respostas dadas na Prancha 1 do TAT.

$57,15 \%$ dos alunos puderam identificar e nomear o violino, mostrando não ter desencadeado uma angústia excessiva, não paralisando o processo de pensamento, bem como de percepção; houve uma percepção integrada do estímulo, revelando integração egóica e conseqüentemente contato com a realidade; perceber o violino e esse sendo equivalente a Psicologia, então perceber o violino equivale perceber a Psicologia.

9,52\% dos alunos tiveram como percepção o violão quando olharam o estímulo, onde constatamos que identificaram o que viram, mas com a presença de mecanismos acentuados de defesa; isso nos leva a refletir que houve uma integração egóica, mas a percepção mostrou-se distorcida, sugerindo a presença de algo ameaçador, tendo ocorrido um deslocamento ${ }^{8}$ do violino para violão. Isso pode ter acontecido, pois possivelmente reativou alguma lembrança que não pôde entrar na consciência, tendo que ter sofrido tal deslocamento.

A relação entre esses sujeitos e a Prancha 1 (Relação Objetal) acabou desencadeando uma angústia que por defesa, ao invés da nomeação ter sido violino, só foi possível ser violão, isso acabou acontecendo para que não entrasse em contato com frustração, a dor, o luto, a angústia levou a criar algo que pudesse defender-se da percepção clara do estímulo.

$4,76 \%$ dos alunos nomearam o estímulo como instrumento musical, ou seja perceberam o global, mas com impossibilidade de entrar em contato com o

\footnotetext{
${ }^{8}$ Fato de a acentuação, o interesse, a intensidade de uma representação ser suscetível de se soltar dela para passar a outras representações originalmente pouco intensas, ligadas à primeira por uma cadeia associativa. Esse fenômeno particularmente visível na análise do sonho, encontra-se na formação dos sintomas psiconeuróticos e, de um modo geral, em todas as formações do inconsciente. A teoria psicanalítica do deslocamento apela para a hipótese econômica de uma energia de investimento suscetível de se desligar das representações e de deslizar por caminhos associativos. O "livre" deslocamento desta energia é uma das características principais do processo primário tal como ele rege o funcionamento do sistema inconsciente. (LAPLANCHE; PONTALIS, 1988)
} 
específico, nomearam dentro de uma categoria ampla, não especificando o tipo de instrumento, o que nos mostrou que houve uma defesa presente nessa percepção; o generalizar mostrou uma percepção global, uma evitação de um olhar mais atento, mais detalhado e específico, aplacando algo ameaçador, persecutório

9,52\% dos alunos tiveram uma percepção distorcida do estímulo, houve uma percepção, mas as defesas para não reconhecer foram tão elevadas que distorceram muito o estímulo em seu reconhecimento e nomeação; houve a percepção e delimitação de uma forma, mas distante do estímulo como realmente ele se apresenta.

Poderíamos estar correlacionando isso com os processos oníricos descritos e estudados por Freud em seus 4 elementos: condensação ${ }^{9}$, deslocamento, figurabilidade ${ }^{10} \mathrm{e}$ elaboração secundária. ${ }^{11}$

Segundo Freud o trabalho onírico tem como finalidade realizar os desejos recalcados que não puderam ser realizados em vigília e que vão manifestar-se através dos sonhos, só que de modo distorcido, irreconhecíveis pela censura (superego), havendo a formação de compromisso.

Reportando-nos a esse tipo de percepção distorcida do estímulo, podemos dizer que elas só puderam sair de uma maneira bem distorcida e deformada, uma vez que a censura foi por demais pronunciada.

19,05\% dos alunos em que houve a presença da negação diante do estímulo violino revelaram uma escotomização (negação da realidade psíquica), pois não puderam chegar perto do estímulo e reconhecê-lo, defendendo-se da proximidade e percepção

\footnotetext{
${ }^{9} \mathrm{Um}$ dos modos essenciais do funcionamento dos processos inconscientes: uma representação única representa por si só várias cadeias associativas, em cuja intersecção se encontra....Vemos operar a condensação no sintoma e, de um modo geral, nas diversas formações do inconsciente. Foi no sonho que melhor foi posta em evidência. (...)(LAPLANCHE; PONTALIS, 1988)

${ }^{10}$ Exigência a que estão submetidos os pensamentos do sonho: eles sofrem uma seleção e uma transformação que os tornam aptos a serem representados em imagens, sobretudo visuais. (LAPLANCHE; PONTALIS, 1988)

${ }^{11}$ Remodelação do sonho destinada a apresentá-lo sob a forma de uma história relativamente coerente e compreensível. (LAPLANCHE; PONTALIS, 1988)
} 
do mesmo através da negação de que ele estava ali presente, não vendo nada, ou não comentando nada a respeito, uma vez que as defesas estavam elevadas; se violino equivale a Psicologia, então escotomizando a percepção do violino, escotomizam também a percepção da Psicologia.

Tendo como base as reparações sugeridas por Bohoslavsky (1982), foram inseridas por nós as reparações autêntica/maníaca e maníaca/autêntica na medida em que houve uma constatação clínica, fazendo-se necessário diante da dinâmica do funcionamento mental e que, até então, não haviam sido propostas; para que pudéssemos chegar a isso, nos detivemos aos elementos citados nas estórias, bem como no contexto em que as mesmas se deram, como o relato foi sendo feito e no tipo de solução apresentada. São elas:

- reparação autêntica/maníaca: quando houve uma integração de ego que percebeu a realidade, mostrando-se coeso, mas que acabou não se mantendo no decorrer do relato da estória, entrando em defesa maníaca;

- reparação maníaca/autêntica: quando iniciou a estória dentro de uma defesa maníaca e no decorrer do relato, foi mostrando uma coesão e maior integração de ego, não se defendendo tanto de modo maníaco, integrando-se mais.

Seguem a apresentação das Tabelas 2 e 3.

Tipos de reparações encontradas nas respostas dadas na Prancha 1 do TAT

\begin{tabular}{|c|c|c|}
\hline Reparação & $\mathrm{N}^{\circ}$. de Alunos & Porcentagem \% \\
\hline Autêntica & 04 & 19,05 \\
\hline Autêntica/Maníaca & 04 & 19,05 \\
\hline Maníaca/Autêntica & 07 & 33,33 \\
\hline Melancólica & 02 & 9,52 \\
\hline Maníaca & 04 & 19,05 \\
\hline Total & 21 & 100,00 \\
\hline
\end{tabular}

TABELA 2 - Tipos de reparações encontradas nas respostas dadas na Prancha 1 do TAT 
Observando a Tabela 2 vamos nos ater apenas a porcentagem mais elevada no que se refere aos tipos de reparações encontradas nas respostas dadas na Prancha 1 do $\mathrm{TAT}^{12}$, a qual mostra aspectos latentes, inconscientes, 33,33\%, foram os que demonstraram reparação maníaca/autêntica, ou seja, que estão nesse momento com uma dinâmica mental mais defendida de modo maníaco, não podendo ter uma percepção mais integrada que os levaria a entrar em contato com a dor, frustração e luto, mas que estão propensos a caminharem para essa integração perceptual tanto dos objetos, quanto egóica, tendo a possibilidade de passarem a fazer uma reparação autêntica.

Tipos de reparações encontradas nas respostas dadas na Entrevista Semidirigida

\begin{tabular}{|c|c|c|}
\hline Reparação & $\mathrm{N}^{\circ}$. de Alunos & Porcentagem \% \\
\hline Autêntica & 12 & 57,15 \\
\hline Autêntica/Maníaca & 01 & 4,76 \\
\hline Maníaca/Autêntica & 05 & 23,81 \\
\hline Melancólica & 01 & 4,76 \\
\hline Maníaca & 02 & 100,52 \\
\hline Total & 21 & \\
\hline
\end{tabular}

TABELA 3 - Tipos de reparações encontradas nas respostas dadas na Entrevista Semidirigida

Na Tabela 3 vamos também nos ater a porcentagem mais elevada no que se refere aos tipos de reparações encontradas nas respostas dadas na Entrevista Semidirigida ${ }^{13}$, que mostram aspectos manifestos, conscientes, 57,15\% demonstraram reparação autêntica, ou seja, a nível manifesto, consciente, uma dinâmica mental menos defendida, com uma percepção integrada, coesa.

Comparando os resultados mais elevados das Tabelas 2 e Tabela 3, pudemos notar que na Prancha 1 do TAT, 33,33\% dos alunos mostraram uma reparação maníaca/autêntica a nível latente, inconsciente e na Entrevista Semidirigida, 57,15\% dos alunos mostraram reparação autêntica a nível manifesto, consciente.

\footnotetext{
${ }^{12}$ Na Tabela 4 faremos uma análise mais detalhada

${ }^{13} \mathrm{Na}$ Tabela 4 faremos uma análise mais detalhada
} 
A Tabela 4 tem como objetivo demonstrar as correlações entre as Tabelas 1, 2 e 3, numa visão mais completa, entrelaçando as percepções do estímulo que os alunos tiveram na Prancha 1, as reparações apresentadas nas estórias da Prancha 1 e as reparações contidas nas respostas dadas na Entrevista Semidirigida.

Relação entre a percepção da Prancha 1, das reparações na Prancha 1, das reparações na Entrevista Semidirigida, do número de alunos e a porcentagem

\begin{tabular}{|c|c|c|c|c|}
\hline $\begin{array}{c}\text { Percepção da } \\
\text { Prancha } 1\end{array}$ & $\begin{array}{c}\text { Reparação na Prancha } \\
1\end{array}$ & $\begin{array}{c}\text { Reparação na } \\
\text { Entrevista } \\
\text { Semidirigida }\end{array}$ & $\begin{array}{l}\mathrm{N}^{\mathrm{o}} . \mathrm{de} \\
\text { Alunos }\end{array}$ & Porcentagem \% \\
\hline Violino & Autêntica & Autêntica & 4 & 19,06 \\
\hline Violino & Melancólica & Melancólica & 1 & 4,76 \\
\hline Violino & Maníaca & Maníaca & 1 & 4,76 \\
\hline Violino & Autêntica/Maníaca & Autêntica & 2 & 9,53 \\
\hline Violino & Maníaca/Autêntica & Autêntica & 2 & 9,53 \\
\hline Violino & Maníaca/Autêntica & Maníaca/Autêntica & 1 & 4,76 \\
\hline Violino & Autêntica/Maníaca & Maníaca/Autêntica & 1 & 4,76 \\
\hline Violão & Autêntica/Maníaca & Autêntica/Maníaca & 1 & 4,76 \\
\hline Violão & Maníaca/Autêntica & Maníaca/Autêntica & 1 & 4,76 \\
\hline Instrumento & Maníaca/Autêntica & Autêntica & 1 & 4,76 \\
\hline Outros Objetos & Maníaca & Autêntica & 1 & 4,76 \\
\hline Outros Objetos & Maníaca/Autêntica & Autêntica & 1 & 4,76 \\
\hline Não viram nada & Maníaca/Autêntica & Maníaca & 1 & 4,76 \\
\hline Não viram nada & Maníaca & Autêntica & 1 & 4,76 \\
\hline Não viram nada & Maníaca & Maníaca/Autêntica & 1 & 4,76 \\
\hline Não viram nada & Melancólica & Maníaca/Autêntica & 1 & 4,76 \\
\hline Total & ------------------------ & |------------------------ & 21 & 100,00 \\
\hline
\end{tabular}

TABELA 4 - Relação entre a percepção da Prancha 1, das reparações na Prancha 1, das reparações na Entrevista Semidirigida, do número de alunos e a porcentagem 
A partir destas correlações pretendemos chegar a visualização e compreensão de como se procedeu a percepção do estímulo e as reparações que acabaram acontecendo, tentando ver de que maneira os conteúdos latente e manifesto se presentificaram. Através desta correlação tentaremos ver o funcionamento da dinâmica mental dos alunos com relação aos mecanismos inconscientes que os motivou a procurar Psicologia.

Da análise da Tabela 4 pudemos observar duas porcentagens que se diferenciaram das demais, são as seguintes:

○ 19,06\% dos alunos tiveram a percepção do violino, apresentando tanto na Prancha 1, quanto na Entrevista Semidirigida, reparação autêntica; isso vem nos mostrar que eles tiveram uma percepção do estímulo integrada, coesa, sendo ambas as reparações autênticas, ou seja, coincidindo conteúdos latente e manifesto, o que dentro do aporte kleiniano denota que estão numa posição depressiva no que se refere à dinâmica mental, podendo entrar em contato com a dor, com a frustração, com o luto, com a perda, possibilitando portanto que o conteúdo seja mais integrado e menos dissociado, estando mais próximos do Princípio de Realidade, em detrimento ao Princípio do Prazer. Em outras palavras, apresentaram um ego mais integrado, mais próximo do contato com a realidade, sem precisarem usar de mecanismos de defesa acentuados.

○ 9,53\% dos alunos tiveram a percepção do violino, apresentando na Prancha 1 reparação do tipo autêntica/maníaca e na Entrevista Semidirigida reparação do tipo autêntica, sendo que os conteúdos latente e manifesto não coincidiram; observamos que a percepção do violino denota uma percepção coesa, integrada; a nível manifesto, consciente, mostraram reparação do tipo autêntica, mas a nível latente, inconsciente, apresentaram reparação do tipo autêntica/maníaca, ou seja, houve a percepção integrada do estímulo, mas algo fez com que os conteúdos não se mantivessem, tendo que a nível latente entrar uma defesa maníaca, pois a defesa maníaca afasta o contato com a dor, luto, perda e frustração.

○ 9,53\% dos alunos tiveram a percepção do violino, apresentando na Prancha 1 reparação do tipo maníaca/autêntica e na Entrevista Semidirigida, reparação do tipo 
autêntica, sendo que os conteúdos latente e manifesto não coincidiram; entendemos que aqui, embora a percepção tenha sido do violino, portanto integrada e coesa, a nível manifesto, consciente, demonstraram reparação autêntica, o que vem mostrar integração, coesão, mas que acaba não se mantendo, pois a nível latente, inconsciente, demonstraram reparação maníaca/autêntica, ou seja, um funcionamento dinâmico mental que oscila ora integrado, ora dissociado, movimentação característica da transição da posição esquizoparanóide para a depressiva., tendendo a aproximar-se da integração egóica e do objeto.

Pudemos observar nessa relação entre as percepções demonstradas na Tabela 4 que houve diversos tipos de reparação apresentados, tanto a nível latente, inconsciente, quanto a nível manifesto, consciente, mas o resultado maior foi exatamente $19,06 \%$ que perceberam o violino e apresentaram tanto na Prancha 1, como na Entrevista Semidirigida, reparação do tipo autêntica, mostrando que esse tipo de reparação sugere a escolha pela Psicologia por um ego que percebe e aceita a realidade, tolera sua ambivalência e consegue realizar tentativas reparatórias, desenvolvendo comportamentos na fantasia e na realidade que procuram reconstruir o objeto danificado; suporta a ansiedade depressiva gerada pela perda, a causa da própria agressão ao objeto bom, do qual depende, capacidade de recriar, tolerar a dor, faz-se responsável por seu ódio a respeito do objeto que simultaneamente era amado e reconhece a culpa.

Notamos também que houve reparações autênticas na Entrevista Semidirigida, portanto a nível manifesto, tendo como percepção da Prancha 1 o violino, instrumento, outros objetos e não viram o objeto, mas não observamos outras reparações autênticas na Prancha 1, portanto a nível latente, além dos 19,06\% dos alunos que viram o violino já citados anteriormente. Isso vem nos mostrar que independente da percepção do estímulo ser ou não integrado, coeso, a nível manifesto houve a reparação autêntica, mas que não se sustentou na reparação da Prancha 1 a nível latente.

Observamos que mesmo o estímulo sendo percebido de modo integral e coeso, as reparações necessariamente não foram autênticas, embora tenha havido coincidências a nível manifesto e latente entre reparações do tipo melancólico, maníaca e maníaca/autêntica. 


\section{CAPÍtulO 9}

\subsection{Conclusão}

Pudemos perceber com a análise dos resultados da Tabela 1, relacionado a percepção do estímulo a nível manifesto, 57,15\% dos alunos viram o violino; se ficarmos apenas com esse dado isolado, teremos a visão de que mais de $50 \%$ desses alunos estão com a percepção e ego integrados, coesos e que, portanto, a percepção que têm do violino, correspondendo com a visão que têm de Psicologia está "adequada", mas comparando essa percepção com os dados referentes as Tabelas 2 e 3 em que temos os tipos de reparação a nível latente, inconsciente e manifesto, consciente, veremos uma discrepância.

Da comparação entre as Tabelas 1 e 3, observamos que as porcentagens mais elevadas coincidiram entre os $57,15 \%$ tanto com os alunos que viram o violino, bem como com a reparação autêntica demonstrada na Entrevista Semidirigida, ou seja, os aspectos a nível manifesto, consciente coincidiram; mais uma vez aqui teríamos a constatação de uma percepção e reparação "adequadas", pois ambas se referem a percepção e reparação coesa, integrada a nível manifesto, consciente.

Quanto aos resultados isolados da Tabela 2, que se refere as reparações a nível latente, inconsciente, vemos que a maior porcentagem foi de 33,33\% que corresponde a uma reparação maníaca/autêntica, o que chama a atenção e se diferencia dos dados observados nas Tabelas 1 e 3 .

Da correlação e análise de todos os dados mencionados nas Tabelas 1, 2 e 3, e contidos na Tabela 4, verificamos que 19,06\% dos alunos perceberam o violino e apresentaram reparação do tipo autêntica, tanto a nível latente, inconsciente, quanto a nível manifesto, consciente, porcentagem diferente da observada nas Tabelas 1 e 3; o que nos leva a concluir que o conteúdo latente tem um peso e importância significativos na questão da "escolha" profissional pelos alunos de Psicologia, nos propiciando uma compreensão da "escolha" além do manifesto, consciente. 
Também constatamos na Tabela 4 que 9,53\% dos alunos tiveram a percepção do violino e na reparação demonstrada na Entrevista Semidirigida a nível manifesto, consciente, foi autêntica, mas a nível latente, inconsciente demonstrada da Prancha 1 do TAT, as reparações não coincidiram, sendo autêntica/maníaca e maníaca/autêntica.

Isto nos leva ao que Coelho Jr. (1997) escreve com relação ao conviver com a tensão permanente entre identidade e diferença, já que neste caso as percepções a nível manifesto foram na maioria dos alunos coincidentes (violino), mas a nível latente apareceram as diferenças, as alteridades e as multiplicidades de conteúdos.

Quando Tescarolli (1999) coloca sobre ter observado a categoria profissional com muitas contradições e ambivalências, levantamos a questão de até que ponto esses aspectos citados por ela não estão relacionados com a questão do manifesto e do latente? Pelos nossos resultados entre a percepção do estímulo e as reparações a nível latente e manifesto, pudemos observar essas contradições e ambivalências.

Voltolini (1999) trata a vocação como sintoma; na nossa pesquisa pudemos constatar que se não levarmos em consideração a questão do conteúdo latente, inconsciente, ficaremos apenas no manifesto, consciente, o que em muitos casos pode ser considerado como sintoma do que não pôde aparecer de modo claro, por ter sido recalcado pela censura.

Bock (1999) diz querer uma Psicologia que se metamorfoseie o tempo todo, acompanhando as mudanças da realidade social do nosso pais; levantamos uma questão aqui: como poderá haver uma mudança social (a nível manifesto, consciente) se não houver uma mudança a nível latente, para que se possa ter consciência daquilo que está inconsciente? Nossa pesquisa mostrou a importância de se considerar também o conteúdo latente, inconsciente.

Retomando a Tabela 4, outra observação que nos chamou a atenção foi a de alunos que tiveram a percepção do violino, mas que a reparação tanto a nível latente, inconsciente, como a nível manifesto, consciente coincidiram em ser do tipo melancólica, maníaca e maníaca/autêntica; entendemos que aqui, embora a percepção tenha sido coesa, 
integrada, as reparações não foram autênticas, mas coincidiram nos conteúdos latente, inconsciente e manifesto, consciente, mostrando uma dinâmica de funcionamento mental defensiva, possivelmente um ego mais frágil que de alguma maneira conseguiu ser coeso em sua percepção, mas com relação ao conteúdo não manteve a mesma coesão e integração, fazendo uso de mecanismos de defesa para que tal percepção não se sustentasse, evitando com isso, entrar em contato com a dor, com a perda, com a frustração, com o luto e com a realidade; correlacionando isto com a "escolha" pela Psicologia, observamos que tal "escolha" se deu em moldes defensivos e não autênticos. Aberastury (1985) coloca que a escolha da vocação no adolescente, desperta angústias e o que dificulta essa decisão da escolha é perder o outro, ou seja, os pais. Mediante isso, levantamos a seguinte questão: de que maneira os alunos que apresentaram reparação do tipo maníaca e melancólica viveram a perda dos pais e fizeram a escolha da vocação? Sabemos que todo mecanismo de defesa é necessário para o desenvolvimento e crescimento psicológico do ser humano, tornando-se patológico quando usado com freqüência e de modo intenso. Isto inclui a mania, pois a mesma é sinônimo de vitalidade, desde que não seja usada como defesa patológica; a melancolia é uma má elaboração do luto, havendo uma identificação com o fracasso, com o objeto perdido. Acreditamos que esses alunos mereçam maior atenção no sentido de receber um apoio psicológico, para poderem lidar de modo diferente com essa e outras perdas, na tentativa de modificarem a dinâmica de funcionamento mental que apresentaram neste momento.

Os 19,06\% dos alunos que pela Tabela 4 tiveram a percepção do violino e reparação do tipo autêntica, tanto a nível latente, inconsciente, quanto a nível manifesto, consciente, mostraram possivelmente um ego mais integrado, coeso e a reparação feita nos níveis latente, inconsciente e manifesto, consciente também acabaram demonstrando conteúdo mais integrado e coeso, refletindo as condições egóicas em que se encontram nesse momento, podendo suportar a angústia, sem precisar livrar-se da mesma, sendo que o mecanismo de defesa, projeção, começou a dar lugar aos mecanismos de recalque, propiciando a condição de lidar melhor com a frustração, com os limites, podendo ver e considerar o outro como um ser separado de si, responsabilizando-se pelos seus atos, reconhecendo a culpa por ter destruído seu objeto amado em fantasia e repará-lo; isto vem nos sugerir que a "escolha" por Psicologia foi feita nesses moldes, por um ego que tem tanto a percepção, quanto conteúdos integrados. 
Fazendo-se uma síntese neste momento dos dados analisados, sugerimos, pelo que foi demonstrado, que nem sempre o aluno que percebeu o estímulo de modo integrado e coeso mostrou reparação autêntica a nível manifesto; e mesmo tendo mostrado, nem sempre coincidiu com a reparação a nível latente; correlacionando isso com a "escolha" que o aluno fez por Psicologia, ter "escolhido" Psicologia não significa necessariamente que a reparação por tal "escolha" tenha sido autêntica a nível manifesto e mesmo tendo sido, nem sempre coincide com a reparação a nível latente, ou seja, há a necessidade de estar se percebendo essas relações: qual a relação que o aluno estabelece quando "escolhe" Psicologia e qual tipo de reparação a nível manifesto e latente tal "escolha" está apoiada.

Toda esta análise nos leva a refletir sobre as condições as quais esses alunos poderão exercer a futura profissão de psicólogo com um ego tão defendido. Novamente nos remetemos ao tripé sine qua non da formação do psicólogo: a supervisão, o estudo de um aporte teórico e a análise pessoal. Acreditamos que o peso maior desse tripé esteja na análise pessoal, pois esse trabalho pode propiciar a possibilidade de uma mudança de dinâmica de funcionamento mental; de acordo com o aporte kleiniano, ajudar a passagem da posição esquizoparanóide para a posição depressiva, ocorrendo com isso a integração do ego bem como dos objetos, podendo os objetos persecutórios e ideais se aproximarem cada vez mais da percepção de como realmente eles são e não como eram vistos; entrar em contato com a perda, com o luto, com a dor, desencadeando a possibilidade de um recriar dos objetos bons destruídos em fantasia e reparados em moldes não maníacos.

Desde que entramos para o curso de Psicologia ouvimos: "Não é possível cuidar e conhecer o mundo mental de uma pessoa se não cuidarmos e conhecermos nosso próprio mundo mental". A pergunta que fica pairando para quem está ingressando no curso é: "Como fazer para cuidarmos e conhecermos nosso próprio mundo mental? Quem procurar?" Sabemos que em alguns cursos de graduação de Medicina existe um setor que dá apoio psicológico e psiquiátrico aos alunos que serão futuros médicos e os alunos de Psicologia , onde buscam esse apoio no curso de graduação? Onde existe esse setor, como na Medicina que propicia tal auxílio? Infelizmente na atualidade não temos 
conhecimento dessa existência institucionalizada, há no entanto, propostas interventivas isoladas.

Da análise kleiniana dos resultados obtidos pudemos constatar que esses alunos vêm reparar os objetos destruídos em fantasia, lidar com suas angústias e querem também tratar do outro, das angústias do outro. Portanto fica a observação de como tratar e acolher o outro em suas angústias se as dos alunos não são acolhidas.

Através das minhas vivências com alunos nos cursos que administro, bem como do relato de colegas também docentes de cursos de Psicologia, pude observar que os alunos traziam (e trazem!!) a seguinte questão: "Se estamos aqui para aprender a cuidar dos outros, quem vai cuidar de nós?". É importante destacarmos essa questão como possibilidade de melhorar a formação profissional desses alunos.

Como foi citado no capítulo sobre o Mito de Édipo, depois de formados temos que seguir sozinhos nosso percurso profissional, solitário, tendo que cada vez mais nos ensimesmar para um autoconhecimento, questão fundamental que nos propiciará entrar em contato com o mundo mental do outro, tarefa árdua e difícil.

No verso abaixo Antonio Machado diz:

“Caminante son tus huellas el camino y nada más, Caminante no hay camino, se hace camino al andar".

Este verso expressa bem como será a trajetória dos alunos depois de formados e o que constatamos é que muito antes disso, ainda na graduação, os alunos jovens, idealistas, muitas vezes rebeldes e até anarquistas em suas idéias, já têm esse percurso a ser feito pela frente, só que despreparados e desprovidos de bagagem para tal caminhada.

Em nossa pesquisa, quando colhíamos os dados com os alunos, isso ficou nítido e notório, pois as perguntas e comentários que eles fizeram após o término da coleta revelaram e denunciaram esse tipo de situação, a angústia mostrada por jovens estudantes que se tornarão, em breve, futuros colegas psicólogos como nós, totalmente desamparados e perdidos. 
Portanto, reforçamos que esse tipo de amparo deverá ser iniciado desde o ingresso na graduação para se poder cada vez mais ter claro qual o perfil dos alunos que procuram o curso de Psicologia. Terá uma dupla finalidade: acolher, conhecer e apoiar o aluno e gerar estudos a respeito disso, o que contribuirá, e muito, para que nossa profissão possa cada vez mais ser respeitada através da boa formação que os alunos possam ter no seu sentido mais amplo e o uso que se faz dessa "escolha" profissional.

Com toda certeza esse trabalho não se encerra aqui, pois há muito a ser investigado ainda a esse respeito, sendo que deixamos a sugestão para novas pesquisas futuras. 


\section{REFERÊNCIAS}

ABERASTURY, A.; KNOBEL; K. Adolescência normal. Porto Alegre: Artes Médicas, 1985.

ABREU FILHO, A. G. Psicólogos e pediatras diante das expectativas dos pais. Revista Pediatria Moderna, v. 34, n. 4, abr. 1998.

ANZIEU, D. Os métodos projetivos. Rio de Janeiro: Campus, 1978.

BELL, J. E. Exploración de la dinámica de la personalidad. Buenos Aires: Paidós, 1964.

BELL, J. E. Técnicas proyectivas exploración de la dinámica de la personalidad. Buenos Aires: Paidós, 1978.

BELLAK, L. Sobre los problemas del concepto de proyección: una teoria de la distorción aperceptiva. In: ABT, L. E.; BELLAK, L. Psicología proyectiva. Buenos Aires: Paidós, 1978a. p. 25-36.

BELLAK, L. El test de apercepción temática en la clínica. In: ABT, L. E.; BELLAK, L. Psicología proyectiva. Buenos Aires: Paidós, 1978b. p. 119-140.

BLEGER, J. Temas em psicologia. São Paulo: Martins Fontes, 1971.

BOCK, A. M. B. A psicologia a caminho do novo século: identidade profissional e compromisso social. Estudos de Psicologia, Natal, v. 4, n. 2, p. 328, dez, 1999. p. 315329.

BOHOSLAVSKY, R. Orientação vocacional: a estratégia clínica. São Paulo: Martins Fontes, 1982.

BOHOSLAVSKY, R. Vocacional - teoria, técnica e ideologia. São Paulo: Cortez, 1983.

CARVALHO, M. M. Orientação profissional em grupo: teoria e técnica. Campinas: Workshopsy, 1995.

COELHO JUNIOR, N. E. A identidade (em crise) do psicólogo. Cadernos de Subjetividade, v. 4 , n. $1 / 2$, p. 311-312, 1997. p. 302-314.

CUNHA, J. A; FREITAS, N. K.; RAYMUNDO, M. G. B. Psicodiagnóstico. Porto Alegre: Artes Médicas, 1989.

DETHLEFSEN, T. Édipo o solucionador de enigmas. São Paulo: Cultrix, 1990.

DIAS, E. T. D. M. A dúvida da continuidade dos estudos universitários. Taubaté: Cabral, 1997. 
DIAS; M. D. O grupo de planejamento de carreira como um holding no resgate da identidade profissional. 2000. Dissertação (Mestrado) - Instituto de Psicologia da Universidade de São Paulo. São Paulo, 2000.

DIAS; M. L. Família e escolha profissional. In: Bock, A.M.B. et al. A escolha profissional em questão. São Paulo: Casa do Psicólogo, 1995. p. 71-91.

DUMORA; B. et al. Les étudiants en psychologie: de l'histoire scolaire au projet universitaire. L'orientacion scolaire et professionnelle, v. 24, n. 2, 1995.

ETCHEGOYEN, R. H. Fundamentos da técnica psicanalítica. 2. ed., amp. Porto Alegre: Artimed, 2004.

FREUD, S. Uma breve descrição da psicanálise. In: Edição Standard Brasileira das Obras Psicológicas Completas de Sigmund Freud. Rio de Janeiro: Imago, 1987. v. 19, (Trabalho original publicado em 1924 [1923]) p. 237-259.

FREUD, S. Formulações sobre os dois princípios do funcionamento mental. In: Edição Standard Brasileira das Obras Psicológicas Completas de Sigmund Freud. Rio de Janeiro: Imago, 1987. v. 12, (Trabalho original publicado em 1911). p. 273-286.

FREUD, S. Narcisismo: uma introdução. In: Edição Standard Brasileira das Obras Psicológicas Completas de Sigmund Freud. Rio de Janeiro: Imago, 1987. v. 14, (Trabalho original publicado em 1914). p. 85-119.

FREUD, S. Romances familiares. In: Edição Standard Brasileira das Obras Psicológicas Completas de Sigmund Freud. Rio de Janeiro: Imago, 1987. v. 9, (Trabalho original publicado em 1909 [1098]) p. 241-247.

FREUD, S. Totem e Tabu. In: Edição Standard Brasileira das Obras Psicológicas Completas de Sigmund Freud. Rio de Janeiro: Imago, 1987. v. 13, (Trabalho original publicado em 1913) p. 13-191.

FREUD, S. Luto e melancolia. In: Edição Standard Brasileira das Obras Psicológicas Completas de Sigmund Freud. Rio de Janeiro: Imago, 1987. v. 14, (Trabalho original publicado em 1917 [1915]) p. 271-291.

FREUD, S. Psicologia de grupo e análise do ego. In: Edição Standard Brasileira das Obras Psicológicas Completas de Sigmund Freud. Rio de Janeiro: Imago, 1987. v. 18, (Trabalho original publicado em 1920) p. 91-179.

GARCÍA ARZENO, M. E. Psicodiagnóstico clínico: novas contribuições. Porto Alegre: Artes Médicas, 1995.

GAY, P. Freud: uma vida para nosso tempo. São Paulo: Cia. das Letras, 1989.

GRASSANO, E. Indicadores psicopatológicos nas técnicas projetivas. São Paulo: Casa do Psicólogo, 1996.

HALL, C. S; LINDZEY, G. Teorias da personalidade. 18. ed. São Paulo: EPU, 1969. v. 2. 
HAMMER, E. F. Tests Proyectivos Gráficos. Buenos Aires: Paidós, 1980.

HINSHELWOOD, R. D. Dicionário do pensamento kleiniano. Porto Alegre: Artes Médicas, 1992.

ISAACS, S. A natureza e a função da fantasia. In Klein, M. et al. Os progressos da psicanálise. Rio de Janeiro: Guanabara, 1986

KLEIN, M. Amor, culpa e reparação. In: Amor, culpa e reparação e outros trabalhos. Rio de Janeiro: Imago, 1996a. (Trabalho original publicado em 1945) p. 346-384.

KLEIN, M. O complexo de Édipo à luz das ansiedades arcaicas. In: Amor, culpa e reparação e outros trabalhos. Rio de Janeiro: Imago, 1996b. (Trabalho original publicado em 1945) p. 416-464.

KLEIN, M. Uma contribuição à psicogênese dos estados maníaco-depressivos. In: Amor, culpa e reparação e outros trabalhos. Rio de Janeiro: Imago, 1996c, p. 301-329. (Trabalho original publicado em 1935)

KLEIN, M. Contribuições à psicanálise: São Paulo: Mestre Jou, 1981a.

KLEIN, M. Inveja e gratidão. In: Inveja e gratidão e outros trabalhos. Rio de Janeiro: Imago, 1991. (Trabalho original publicado em 1957) p. 205-267

KLEIN, M. Notas sobre alguns mecanismos esquizóides. In: Inveja e gratidão e outros trabalhos. Rio de Janeiro: Imago, 1991. (Trabalho original publicado em 1946) p. 17-43

KLEIN, M. Psicanálise da criança. São Paulo: Mestre Jou, 1981 b.

LAPLANCHE; J., PONTALIS; J. B. Vocabulário da psicanálise. São Paulo: Martins Fontes, 1988.

LEHMAN; Y .P. A aquisição da identidade vocacional em uma sociedade em crise: 2 Momentos na profissão liberal. 1988. Tese (Doutorado) - Instituto de Psicologia da Universidade de São Paulo. São Paulo, 1988.

LEHMAN; Y .P O processo de orientação profissional como um holding na adolescência. In: CATAFESTA, I. F. M. (Org). D.W. Winnicott na Universidade de São Paulo. São Paulo: Instituto de Psicologia da Universidade de São Paulo, 1996. p. 277289.

LEVENFUS; R. S.; SOARES; D. H. P. Orientação vocacional ocupacional. Porto Alegre: Artmed, 2002.

MELLO, S. L. Psicologia e profissão em São Paulo. São Paulo: Ática, 1975.

MURRAY, H. Test de Apercepción Temática - Manual para la Aplicación. Buenos Aires: Paidós, 1951. 
NASCIMENTO; R. S. G. F. Sublimação, reparação e a escolha profissional. In: Bock, A.M.B. et al. A escolha profissional em questão. São Paulo: Casa do Psicólogo, 1995.

PETOT, J. M. Melanie Klein I. São Paulo: Perspectiva, 1987.

PETOT, J. M Melanie Klein II. São Paulo: Perspectiva, 1992.

RAPPAPORT, C. R. et al. Adolescência: abordagem psicanalítica. São Paulo: EPU, 1993.

RIBEIRO, E. M. P. C. O exercício do papel de psicoterapeuta por psicólogos: identificação de alguns fatores presentes à escolha. São Paulo, 1991. Tese (Doutorado) - Instituto de Psicologia da Universidade de São Paulo. São Paulo, 1991.

RYAN, A. M.; CHAN, M. Perceptions of the EPPP: how do candidates view the process? Professional Psychology: Research and Practice, v. 30, n. 5, p. 519, 1999. p.519-529.

SANTOS, M. F. S. Formar Psicólogos para quê?. Ver. Psicologia Ciência e Profissão, v. 4, n. 1/3, p. 40-41, 1994. p. 40-41.

SCHMIDT; M. L. S. Psicologia: Representações da Profissão.1984. Dissertação (Mestrado) - Instituto de Psicologia da Universidade de são Paulo. São Paulo, 1984.

SEGAL, H. Introdução à obra de Melanie Klein. Rio de Janeiro: Imago, 1975.

SHENTOUB, V. et al. Manuel D’Utilisation du T.A.T. (Approche psychanalytique). Paris: Dunod, 1990.

SILVA; L. B. C. A escolha da profissão: uma abordagem psicossocial. São Paulo: Unimarco, 1996.

SILVA; M. C. V. M. TAT: aplicação e interpretação do Teste de Apercepção Temática. São Paulo: E.P.U, 1989.

SINDICATO DOS PSICÓLOGOS NO ESTADO DE SÃO PAULO E CRP-06. O perfil do psicólogo no Estado de São Paulo. São Paulo: Cortez, 1984.

SOUZA; S. P. Diagnóstico de orientação profissional: o uso do TAT. In: A escolha profissional em questão. São Paulo: Casa do Psicólogo, 1995.

SULlIVAN, H. S. La entrevista psiquiátrica. Buenos Aires: Psique, 1959.

TESCAROLLI, L. Identidade e profissão: um estudo sobre a identidade do psicólogo e professor universitário e clínico. 1999. Dissertação (Mestrado) - Instituto de Psicologia da Universidade de São Paulo. São Paulo, 1999.

ULHOA CINTRA, E. M.; FIGUEIREDO, L. C. Melanie Klein: estilo e pensamento. São Paulo: Escuta, 2004. 
VAN KOLCK, O. L. Técnicas do exame psicológico e suas aplicações no Brasil. 2. ed. Petrópolis: Vozes, 1981. 2 v.

VOLTOLINI, R. A questão da vocação: psicanálise e psicologia. 1999. Tese (Doutorado) Instituto de Psicologia da Universidade de São Paulo. São Paulo, 1999. 
ANEXO A

RELATO DAS PERGUNTAS E RESPOSTAS DA ENTREVISTA SEMIDIRIGIDA FEITA AOS ALUNOS DE $1^{\circ}$. E $2^{\circ}$. ANOS DE PSICOLOGIA 


\section{RELATO DAS PERGUNTAS E RESPOSTAS DA ENTREVISTA SEMIDIRIGIDA FEITA AOS ALUNOS DE \\ $1^{\circ}$. E $2^{\circ}$. ANOS DE PSICOLOGIA}

\begin{tabular}{|c|c|c|}
\hline Alunos & $\begin{array}{l}\text { O que o(a) levou a procurar } \\
\text { Psicologia? }\end{array}$ & Foi sua primeira opção? \\
\hline S01 & $\begin{array}{l}\text { Não sei sempre tive interesse por essa } \\
\text { questão de mente, mas não medicina; } \\
\text { nunca gostei de Freud, sempre me } \\
\text { chamou a atenção a mente, algo } \\
\text { inconsciente que não a coisa pura e } \\
\text { simples de estar fazendo algo. }\end{array}$ & $\begin{array}{l}\text { Não, a primeira opção foi audiovisual, } \\
\text { trabalhar com algo na área de cinema e } \\
\text { literatura; não passei em audiovisual; } \\
\text { meu pai está numa situação financeira } \\
\text { complicada e não teria como me } \\
\text { bancar; prestei Psicologia e entrei. }\end{array}$ \\
\hline S02 & $\begin{array}{l}\text { Estava na dúvida entre Relações } \\
\text { Públicas, Psicologia e Jornalismo; fiz } \\
\text { Orientação Vocacional e os testes } \\
\text { sempre davam área de humanas; } \\
\text { minha mãe sempre falou para eu fazer } \\
\text { Psicologia, mas eu gostava de } \\
\text { esportes. Dentro da Psicologia quero } \\
\text { mais área de esporte ou hospitalar, } \\
\text { mas estou em dúvida. As pessoas me } \\
\text { ligam para ajudá-las e eu gosto disso; } \\
\text { desde pequena gosto de ouvir as } \\
\text { pessoas, de ajudar, de dar conselhos. }\end{array}$ & Não. \\
\hline S03 & $\begin{array}{l}\text { Acho que....é uma lição de vida para } \\
\text { qualquer pessoa. A forma de pensar, o } \\
\text { aprendizado que a gente pode ter } \\
\text { através da Psicologia. }\end{array}$ & $\begin{array}{l}\text { Não, quando eu era criança foi ser } \\
\text { professora, depois Psicologia mesmo. }\end{array}$ \\
\hline S04 & A entender a mente dos outros. & Sim. \\
\hline S05 & $\begin{array}{l}\text { Conheci um psicólogo alemão numa } \\
\text { viagem e me impressionou muito ver } \\
\text { aquele homem falar tanto da vida e } \\
\text { pensei "é isso que eu quero para mim, } \\
\text { passar meus conhecimentos". }\end{array}$ & $\begin{array}{l}\text { Não, veterinária, decoração, } \\
\text { jornalismo e tinha certeza que era } \\
\text { Direito. Daí conheci esse psicólogo. }\end{array}$ \\
\hline
\end{tabular}




\begin{tabular}{|c|c|c|}
\hline Alunos & $\begin{array}{l}\text { O que o(a) levou a procurar } \\
\text { Psicologia? }\end{array}$ & Foi sua primeira opção? \\
\hline S06 & $\begin{array}{l}\text { Os problemas da minha casa, desde a } \\
\text { minha infância, relacionamento dos } \\
\text { meus pais com meus irmãos e eu acho } \\
\text { que eu tinha que fazer alguma coisa, } \\
\text { eles não conseguiriam. Sinto-me muito } \\
\text { rejeitada, foi uma forma de me } \\
\text { entender. }\end{array}$ & Sim, Psicologia e Nutrição. \\
\hline \begin{tabular}{|l|} 
S07 \\
\end{tabular} & $\begin{array}{l}\text { Sempre quis uma profissão que } \\
\text { ajudasse as pessoas, não medicina, } \\
\text { porque eu não posso ver sangue; gosto } \\
\text { de ouvir e ajudar, combina comigo } \\
\text { isso. }\end{array}$ & $\begin{array}{l}\text { Não, pensei antes em fazer Fono, } \\
\text { depois pensei melhor e achei melhor } \\
\text { fazer Psicologia; na hora que eu pensei } \\
\text { na Fono foi uma influência de minha } \\
\text { tia, onde depois de um tempo eu teria } \\
\text { onde estagiar e ela dizia que } \\
\text { Psicologia era difícil; minha tia faz } \\
\text { acupuntura, mas conhece quem } \\
\text { poderia indicar para eu fazer estágio. }\end{array}$ \\
\hline S08 & $\begin{array}{l}\text { Desde pequena tive curiosidade em } \\
\text { saber o que se passa na cabeça de uma } \\
\text { pessoa, elas vêm falar comigo; da } \\
\text { gente poder ajudar e encaminhá-las. }\end{array}$ & $\begin{array}{l}\text { Não, por estudar no Colégio } \\
\text { Bandeirantes, me vi forçada a fazer } \\
\text { medicina; no } 3^{\circ} \text {. Ano do Colegial } \\
\text { prestei medicina e não era isso que eu } \\
\text { queria. Fiz uma viagem para fora, } \\
\text { conheci muita gente, voltei, fiz } \\
\text { cursinho e entrei em Psicologia. }\end{array}$ \\
\hline S09 & $\begin{array}{l}\text { Tinha começado outra faculdade, } \\
\text { Administração, desde os } 13 \text { anos } \\
\text { penso em fazer Administração. Por } \\
\text { minha mãe ser psicóloga, eu não } \\
\text { queria; eu fazia terapia, tinha contato } \\
\text { com Psicologia. }\end{array}$ & Não. \\
\hline
\end{tabular}




\begin{tabular}{|c|c|c|}
\hline Alunos & $\begin{array}{l}\text { O que o(a) levou a procurar } \\
\text { Psicologia? }\end{array}$ & Foi sua primeira opção? \\
\hline S10 & $\begin{array}{l}\text { Sempre fiquei no dilema, conformado } \\
\text { com a situação do mundo de hoje em } \\
\text { dia. Fazer algo para ajudar as pessoas, } \\
\text { mudar o mundo; uma coisa mais de } \\
\text { interação. Dilema de não esquecer que } \\
\text { estamos numa sociedade capitalista, } \\
\text { onde você tem que se sustentar, ajudar } \\
\text { a sociedade e a mim mesmo e a meus } \\
\text { filhos; me interessava por } \\
\text { comportamento e cérebro humano. }\end{array}$ & Sim. \\
\hline S11 & $\begin{array}{l}\text { Fiz Ciências Sociais, depois Filosofia, } \\
\text { parei e acabei gostando mais de } \\
\text { Psicologia. É uma ciência que dá mais } \\
\text { significado para as coisas, é uma coisa } \\
\text { que tenho prazer em ler, estou mais } \\
\text { motivada. }\end{array}$ & $\begin{array}{l}\text { Sabia que queria fazer Psicologia, mas } \\
\text { fui testar outras antes. }\end{array}$ \\
\hline S12 & $\begin{array}{l}\text { Não sabia o que queria, pensei em } \\
\text { medicina e fisioterapia, queria ajudar } \\
\text { as pessoas conversando com elas, vi } \\
\text { que fisioterapia era um pretexto. Na } \\
\text { véspera do vestibular me inscrevi em } \\
\text { Psicologia, porque minha mãe sempre } \\
\text { falou isso, ela é psicóloga, mas não } \\
\text { exercita. }\end{array}$ & Não. \\
\hline
\end{tabular}




\begin{tabular}{|c|c|c|}
\hline Alunos & $\begin{array}{l}\text { O que o(a) levou a procurar } \\
\text { Psicologia? }\end{array}$ & Foi sua primeira opção? \\
\hline S13 & $\begin{array}{l}\text { Sou formada em Pedagogia; trabalhei } \\
\text { no SESC com grupo de idosos e senti } \\
\text { falta de um instrumental para lidar } \\
\text { com certas situações; idéia de morte, } \\
\text { eu não sabia como lidar com isso } \\
\text { quando morria alguém do grupo. A } \\
\text { Psicologia dá esse instrumental de } \\
\text { mediação entre as pessoas. }\end{array}$ & Não. \\
\hline S14 & $\begin{array}{l}\text { Acho que todos deveriam ter uma } \\
\text { noção de Psicologia, se entender } \\
\text { melhor e entender melhor os outros, } \\
\text { conseguir se relacionar melhor com os } \\
\text { outros. }\end{array}$ & $\begin{array}{l}\text { Não, fiquei muito em dúvida; quis ser } \\
\text { biólogo no vestibular; dúvida entre } \\
\text { arquitetura e Psicologia. O que me } \\
\text { levou a fazer Psicologia foi o que falei } \\
\text { antes. }\end{array}$ \\
\hline S15 & $\begin{array}{l}\text { Foi difícil escolher, gostava de muitas } \\
\text { coisas e ia bem em todas as áreas. } \\
\text { Procurei Orientação Vocacional com } \\
\text { uma psicóloga e na escola também; } \\
\text { pesquisei algumas coisas e fiz alguns } \\
\text { testes. Tive uma tendência mais } \\
\text { acentuada para Artes e empatou com } \\
\text { Área Social. Veio a idéia de fazer } \\
\text { Psicologia no cômputo geral; cheguei } \\
\text { a entrevistar uma psicóloga e gostei do } \\
\text { campo. }\end{array}$ & $\begin{array}{l}\text { A primeira opção como professora foi } \\
\text { até os } 10 \text { anos e depois mudei de idéia; } \\
\text { quis ser escritora, fazer História, } \\
\text { Física, Letras, medicina homeopática e } \\
\text { acabei indo para Psicologia; só prestei } \\
\text { vestibular pra Psicologia. }\end{array}$ \\
\hline S16 & $\begin{array}{l}\text { Não sei dizer, sempre quis, me } \\
\text { interessei, não foi uma coisa assim } \\
\text { "foi isso"; não tem nenhum psicólogo } \\
\text { na minha família, eu sempre quis } \\
\text { mesmo. }\end{array}$ & Sim. \\
\hline
\end{tabular}




\begin{tabular}{|c|c|c|}
\hline Alunos & $\begin{array}{l}\text { O que o(a) levou a procurar } \\
\text { Psicologia? }\end{array}$ & Foi sua primeira opção? \\
\hline S17 & $\begin{array}{l}\text { Sou formada em Pedagogia; trabalhei } \\
\text { no SESC com grupo de idosos e senti } \\
\text { falta de um instrumental para lidar } \\
\text { com certas situações; idéia de morte, } \\
\text { eu não sabia como lidar com isso } \\
\text { quando morria alguém do grupo. A } \\
\text { Psicologia dá esse instrumental de } \\
\text { mediação entre as pessoas. }\end{array}$ & $\begin{array}{l}\text { Primeira coisa foi Medicina, depois } \\
\text { Direito e aí Psicologia. }\end{array}$ \\
\hline S18 & $\begin{array}{l}\text { Procurar entender os animais, a terapia } \\
\text { que faço há } 7 \text { anos. Desde pequena fui } \\
\text { sempre conselheira, pensei em seguir } \\
\text { Direito, não gostei de julgar. Com } 7 / 8 \\
\text { anos me interessei por comportamento } \\
\text { animal. Quero ajudar como estou } \\
\text { sendo ajudada (nesse momento } \\
\text { começa a chorar) }\end{array}$ & $\begin{array}{l}\text { Não, quis ser quase tudo; o mais } \\
\text { remoto foi astronauta, mas eu era bem } \\
\text { pequena. }\end{array}$ \\
\hline S19 & $\begin{array}{llr}\text { Decidi não } & \text { fazer nada em Ciências } \\
\text { Exatas; } & \text { achava } & \text { Psicanálise } \\
\text { interessante, ouvia dizer que psicólogo } \\
\text { não gostava de ler e questionava isso. } \\
\text { Pretendo seguir área acadêmica que eu } \\
\text { gosto, não pretendo clinicar, Recursos } \\
\text { Humanos eu detesto; pesquisar sim. }\end{array}$ & Sim. \\
\hline
\end{tabular}




\begin{tabular}{|c|c|c|}
\hline Alunos & $\begin{array}{l}\text { O que o(a) levou a procurar } \\
\text { Psicologia? }\end{array}$ & Foi sua primeira opção? \\
\hline S20 & $\begin{array}{l}\text { Parece-me que o objeto da Psicologia } \\
\text { é o que mais me interessa; o mundo } \\
\text { psicológico, as vicissitudes da vida, } \\
\text { como você estrutura suas vivências, } \\
\text { discutir e se falar. Tenho tendência a } \\
\text { Ciências Humanas, porque talvez } \\
\text { tinham pessoas em minha família das } \\
\text { Ciências Humanas. O seu enfoque eu } \\
\text { gosto para se discutir, mergulhar no } \\
\text { problema, é mais profunda e a questão } \\
\text { terapêutica também me interessa. }\end{array}$ & $\begin{array}{l}\text { Não, era Letras e depois Psicologia; no } \\
3^{\circ} \text {. Colegial é que decidi fazer } \\
\text { Psicologia. }\end{array}$ \\
\hline S21 & $\begin{array}{l}\text { Ano passado fiz } 2 \text { meses de Filosofia e } \\
\text { teve greve; de última troquei direto } \\
\text { para Psicologia; é mais para área de } \\
\text { humanas que eu sempre quis. }\end{array}$ & $\begin{array}{l}\text { Não, foi Filosofia, Direito, Jornalismo } \\
\text { Ciências Sociais. }\end{array}$ \\
\hline
\end{tabular}




\begin{tabular}{|c|c|c|}
\hline Alunos & $\begin{array}{l}\text { Você tem algum conhecimento acerca } \\
\text { das áreas em que a Psicologia atua? }\end{array}$ & Já pensou em escolher alguma? \\
\hline S01 & $\begin{array}{l}\text { Algum conhecimento: pesquisa, } \\
\text { escola, todas as áreas dá para } \\
\text { encontrar Psicologia se quiser, } \\
\text { inclusive audiovisual. }\end{array}$ & $\begin{array}{l}\text { Penso escolher pesquisa, mas vai } \\
\text { depender dos } 4 / 5 \text { anos pela frente. }\end{array}$ \\
\hline S02 & Não. & Também não. \\
\hline S03 & $\begin{array}{l}\text { Hospitalar, esporte, empresas, infantil, } \\
\text { penitenciário, direito. }\end{array}$ & Pretendo penitenciária. \\
\hline S04 & $\begin{array}{l}\text { Gostaria de trabalhar com ludoterapia, } \\
\text { adolescentes e adultos; gostaria de } \\
\text { experenciar trabalhar com loucos em } \\
\text { manicômios, em hospital; tenho } \\
\text { conhecimento dessas áreas. }\end{array}$ & Respondida na anterior. \\
\hline S05 & $\begin{array}{l}\text { Área de publicidade, Psicologia do } \\
\text { consumidor, mas já pensei em } \\
\text { trabalhar com esporte e jurídica. } \\
\text { Sonho em fazer uma área de pesquisa } \\
\text { e palestra e fazer um livro. }\end{array}$ & Respondida na anterior. \\
\hline S06 & $\begin{array}{l}\text { Clínica, hospitalar, } \quad \text { Recursos } \\
\text { Humanos, animal, social. }\end{array}$ & $\begin{array}{l}\text { Quero ou clínica, ou social, se possível } \\
\text { as duas. }\end{array}$ \\
\hline S07 & $\begin{array}{l}\text { Minha prima faz Psicologia e comenta } \\
\text { que quer trabalhar com Deficientes } \\
\text { Mentais e idosos. }\end{array}$ & Não sei o que vou optar. \\
\hline S08 & $\begin{array}{l}\text { Clínica, Recursos Humanos, hospitais, } \\
\text { escola, prisão, só. }\end{array}$ & $\begin{array}{l}\text { Queria experimentar de tudo, mas } \\
\text { penso bastante em Recursos Humanos } \\
\text { e mais pra frente ter minha clínica e } \\
\text { em paralelo participar de alguma } \\
\text { ONG, sem pensar em dinheiro. }\end{array}$ \\
\hline S09 & $\begin{array}{l}\text { Mesmo minha mãe sendo psicóloga, } \\
\text { conheço pouco; Psicologia e } \\
\text { Psicanálise, têm muitas áreas. }\end{array}$ & $\begin{array}{l}\text { Área clínica e partir para a Psicanálise, } \\
\text { algo que me permita escrever; fusão } \\
\text { entre Arte e Psicanálise. }\end{array}$ \\
\hline
\end{tabular}




\begin{tabular}{|c|c|c|}
\hline Alunos & $\begin{array}{l}\text { Você tem algum conhecimento acerca } \\
\text { das áreas em que a Psicologia atua? }\end{array}$ & Já pensou em escolher alguma? \\
\hline S10 & $\begin{array}{l}\text { Muito pouco; agora estou tendo } \\
\text { contato com behaviorismo, li Freud. } \\
\text { Hospitalar, onde ela atua, mas não } \\
\text { tenho muitas informações; Psicologia } \\
\text { do esporte, educacional, clínica, } \\
\text { empresarial, do direito. }\end{array}$ & $\begin{array}{l}\text { Acho muito difícil fazer uma escolha } \\
\text { sem muito conhecimento; no momento } \\
\text { tento entender melhor. }\end{array}$ \\
\hline S11 & Clínica, hospitalar, escolar. & $\begin{array}{l}\text { Acho que clínica; também gosto de } \\
\text { Recursos Humanos, o trabalho com } \\
\text { escola; ou clinica, ou Recursos } \\
\text { Humanos, ou os dois. }\end{array}$ \\
\hline S12 & $\begin{array}{l}\text { Clínica, hospitalar, educacional, } \\
\text { Recursos Humanos, esporte. }\end{array}$ & $\begin{array}{l}\text { Penso em fazer hospitalar, mas não } \\
\text { fechei, pensei também em escolar e } \\
\text { clínica. }\end{array}$ \\
\hline S13 & $\begin{array}{l}\text { Clínica, Recursos Humanos, } \\
\text { hospitalar, aconselhamento genético } \\
\text { numa equipe multiprofissional, } \\
\text { cuidadores de idosos, escolar. }\end{array}$ & Ainda não sei. \\
\hline S14 & $\begin{array}{l}\text { Publicidade, escola, hospitalar, clínica, } \\
\text { Recursos Humanos. }\end{array}$ & $\begin{array}{l}\text { Ainda não sei, mas tenho preferência } \\
\text { por clinicar, mas não decidi. }\end{array}$ \\
\hline S15 & $\begin{array}{l}\text { Psicanálise, analítica, gestalt, indústria } \\
\text { em recursos humanos, escolar e } \\
\text { hospitalar. }\end{array}$ & $\begin{array}{l}\text { Não gosto da experimental, enjoou; } \\
\text { gosto de Jung e Gestalt. }\end{array}$ \\
\hline S16 & $\begin{array}{l}\text { Muito pouco: comportamental, } \\
\text { Psicanálise, cognitiva, gestalt. }\end{array}$ & $\begin{array}{l}\text { Eu sei qual não quero: } \\
\text { comportamental. }\end{array}$ \\
\hline S17 & 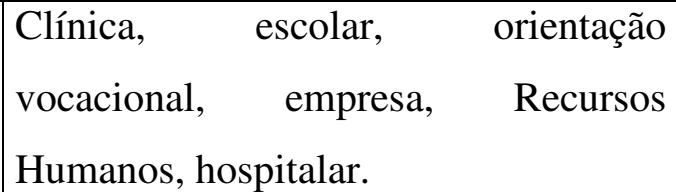 & $\begin{array}{l}\text { Penso em clínica, mas posso mudar de } \\
\text { idéia. }\end{array}$ \\
\hline
\end{tabular}




\begin{tabular}{|c|c|c|}
\hline Alunos & $\begin{array}{l}\text { Você tem algum conhecimento acerca } \\
\text { das áreas em que a Psicologia atua? }\end{array}$ & Já pensou em escolher alguma? \\
\hline S18 & $\begin{array}{l}\text { Minha irmã está terminando o curso } \\
\text { de Psicologia. Clínica, educacional, } \\
\text { comportamento animal, hospitalar. }\end{array}$ & Não sei o que seguir ainda. \\
\hline S19 & Marketing. & Pretendo pesquisa a princípio. \\
\hline S20 & Clínica, escolar, organizacional. & Penso em clínica. \\
\hline S21 & $\begin{array}{l}\text { Escolar, exame de motorista, } \\
\text { psicotécnico, de ajuda aos presos e sua } \\
\text { família, clínica, terapia, empresas para } \\
\text { Recursos Humanos. }\end{array}$ & $\begin{array}{l}\text { Pensei um monte; Psicologia Socia } \\
\text { me interessa mais; pelo dinheirc } \\
\text { desincentiva um pouco. }\end{array}$ \\
\hline
\end{tabular}




\begin{tabular}{|c|c|c|}
\hline Alunos & Formação e idade dos pais & Profissão dos pais \\
\hline S01 & $\begin{array}{l}\text { Pai: superior - } 61 \text { anos (acho) } \\
\text { Mãe: superior - } 48 \text { anos (acho) }\end{array}$ & $\begin{array}{l}\text { Pai: Engenheiro } \\
\text { Mãe: Dentista (não atua) }\end{array}$ \\
\hline S02 & $\begin{array}{l}\text { Pai: economia }-47 \text { anos } \\
\text { Mãe: Turismo - } 51 \text { anos }\end{array}$ & $\begin{array}{l}\text { Pai: Diretor Financeiro } \\
\text { Mãe: não atua }\end{array}$ \\
\hline S03 & $\begin{array}{l}\text { Pai: superior - } 59 \text { anos } \\
\text { Mãe: superior - } 51 \text { anos }\end{array}$ & $\begin{array}{l}\text { Pai: Empresário } \\
\text { Mãe: Professora }\end{array}$ \\
\hline S04 & $\begin{array}{l}\text { Pai: Economia - } 56 \text { anos } \\
\text { Mãe: Artista Plástica - } 54 \text { anos }\end{array}$ & $\begin{array}{l}\text { Pai: atua na área } \\
\text { Mãe: atua na área }\end{array}$ \\
\hline S05 & $\begin{array}{l}\text { Pai: Administração de Empresa - } 54 \\
\text { anos (eu acho) } \\
\text { Mãe: fez Filosofia - } 52 \text { anos }\end{array}$ & $\begin{array}{l}\text { Pai: Consultor } \\
\text { Mãe: fazendo mestrado }\end{array}$ \\
\hline S06 & $\begin{array}{l}\text { Pai: Técnico de usinagem - } 58 \text { anos } \\
\text { Mãe: Psicopedagoga - } 52 \text { anos }\end{array}$ & $\begin{array}{l}\text { Pai: atua na área } \\
\text { Mãe: aposentada }\end{array}$ \\
\hline S07 & $\begin{array}{l}\text { Pai: Engenheiro }-48 \text { anos } \\
\text { Mãe: não se formou, sempre quis ser } \\
\text { arquiteta - } 46 \text { anos }\end{array}$ & $\begin{array}{l}\text { Pai: Empresário de produtos hospitalar } \\
\text { Mãe: do lar }\end{array}$ \\
\hline S08 & $\begin{array}{l}\text { Pai: Administração de Empresa - } 49 \\
\text { anos } \\
\text { Mãe: Publicidade e Pedagogia - } 46 \\
\text { anos }\end{array}$ & $\begin{array}{l}\text { Pai: atua na área } \\
\text { Mãe: Orientadora Escolar }\end{array}$ \\
\hline S09 & $\begin{array}{l}\text { Pai: Médico - } 51 \text { anos } \\
\text { Mãe: Psicóloga - } 48 \text { anos }\end{array}$ & $\begin{array}{l}\text { Pai: atua na área } \\
\text { Mãe: atua na área }\end{array}$ \\
\hline S10 & $\begin{array}{l}\text { Pai: Economista - } 50 \text { anos (eu acho) } \\
\text { Mãe: Administração de Empresa - } 47 \\
\text { anos }\end{array}$ & $\begin{array}{l}\text { Pai: dá curso em treinamento para } \\
\text { consultoria } \\
\text { Mãe: trabalhou em RH em empresa; } \\
\text { hoje parou de exercer e atua em ONGs }\end{array}$ \\
\hline S11 & $\begin{array}{l}\text { Pai: Ginecologista - } 55 \text { anos (eu acho) } \\
\text { Mãe: Assistente Social (não atua) - } 45 \\
\text { anos }\end{array}$ & $\begin{array}{l}\text { Pai: atua na área } \\
\text { Mãe: Estética Corporal }\end{array}$ \\
\hline S12 & $\begin{array}{l}\text { Pai: Psiquiatra - } 50 \text { anos } \\
\text { Mãe: Psicóloga - } 50 \text { anos }\end{array}$ & $\begin{array}{l}\text { Pai: atua na área mais como } \\
\text { psicoterapeuta } \\
\text { Mãe: não atua }\end{array}$ \\
\hline
\end{tabular}




\begin{tabular}{|c|c|c|}
\hline Alunos & Formação e idade dos pais & Profissão dos pais \\
\hline S13 & $\begin{array}{l}\text { Pai: Engenheiro Agrônomo - } 57 \text { anos } \\
\text { Mãe: fez História - } 57 \text { anos }\end{array}$ & $\begin{array}{l}\text { Pai: atua na área } \\
\text { Mãe: não atua }\end{array}$ \\
\hline S14 & $\begin{array}{l}\text { Pai: Engenharia Civil e Direito - } 50 \\
\text { anos } \\
\text { Mãe: Arquiteta - } 51 \text { anos }\end{array}$ & $\begin{array}{l}\text { Pai: Oficial de Justiça } \\
\text { Mãe: atua na área }\end{array}$ \\
\hline S15 & $\begin{array}{l}\text { Pai: Químico - } 47 \text { anos } \\
\text { Mãe: Química - } 42 \text { anos }\end{array}$ & $\begin{array}{l}\text { Pai: atua na área } \\
\text { Mãe: não atua }\end{array}$ \\
\hline S16 & $\begin{array}{l}\text { Pai: administra obras - } 48 \text { ou } 49 \text { anos } \\
\text { Mãe: Pedagoga e Economista - } 45 \\
\text { anos }\end{array}$ & $\begin{array}{l}\text { Pai: aposentado, dá alguns cursos na } \\
\text { Petrobrás } \\
\text { Mãe: Pedagoga }\end{array}$ \\
\hline S17 & $\begin{array}{l}\text { Pai: Economia - } 62 \text { anos } \\
\text { Mãe: } 2^{\circ} . \text { Grau incompleto }-53 \text { anos }\end{array}$ & $\begin{array}{l}\text { Pai: aposentado } \\
\text { Mãe: professora do Kumon }\end{array}$ \\
\hline S18 & $\begin{array}{l}\text { Pai: superior incompleto }-59 \text { anos } \\
\text { Mãe: segundo grau incompleto }-49 \\
\text { anos }\end{array}$ & $\begin{array}{l}\text { Pai: aposentado } \\
\text { Mãe: comércio }\end{array}$ \\
\hline S19 & $\begin{array}{l}\text { Pai: } 1^{\circ} . \text { Grau completo }- \text { falecido aos } \\
52 \text { anos } \\
\text { Mãe: } 2^{\circ} \text {. Grau incompleto }-47 \text { anos }\end{array}$ & $\begin{array}{l}\text { Pai: falecido } \\
\text { Mãe: nunca trabalhou }\end{array}$ \\
\hline S20 & $\begin{array}{l}\text { Pai: Economia - } 48 \text { anos } \\
\text { Mãe: Letras - } 43 \text { anos }\end{array}$ & $\begin{array}{l}\text { Pai: Corretor de imóveis } \\
\text { Mãe: Professora Universitária } \\
\text { doutorado em } \\
\text { Comunicação }\end{array}$ \\
\hline S21 & $\begin{array}{l}\text { Pai: Engenheiro - } 50 \text { anos } \\
\text { Mãe: superior incompleto - } 44 \text { anos }\end{array}$ & $\begin{array}{l}\text { Pai: Co-proprietário de uma empresa } \\
\text { de engenharia } \\
\text { Mãe: do lar - vende roupas e massas }\end{array}$ \\
\hline
\end{tabular}




\begin{tabular}{|c|c|c|}
\hline Alunos & Irmãos: idade & Irmãos: o que fazem \\
\hline S01 & $\begin{array}{l}\text { Irmã: } 25 \text { anos } \\
\text { Irmão: } 23 \text { anos }\end{array}$ & $\begin{array}{l}\text { Irmã: Zootecnia } \\
\text { Irmão: Artes Plásticas e é fotógrafo da } \\
\text { polícia }\end{array}$ \\
\hline S02 & $\begin{array}{l}\text { Irmã: } 22 \text { anos } \\
\text { Irmão: } 21 \text { anos }\end{array}$ & $\begin{array}{l}\text { Irmã: Direito } \\
\text { Irmão: Publicidade }\end{array}$ \\
\hline S03 & Irmão: 22 anos & Irmão: Direito \\
\hline S04 & $\begin{array}{l}\text { Irmão: } 30 \text { anos } \\
\text { Irmão: } 29 \text { anos }\end{array}$ & $\begin{array}{l}\text { Irmão: Mercado Financeiro } \\
\text { Irmão: Arquitetura }\end{array}$ \\
\hline S05 & $\begin{array}{l}\text { Irmão: } 24 \text { anos } \\
\text { Irmão: } 22 \text { anos }\end{array}$ & $\begin{array}{l}\text { Irmão: Direito } \\
\text { Irmão: Educação Física }\end{array}$ \\
\hline S06 & $\begin{array}{l}\text { Irmão: } 24 \text { anos } \\
\text { Irmão: } 20 \text { anos }\end{array}$ & $\begin{array}{l}\text { Irmão: Direito } \\
\text { Irmão: Engenharia de computação }\end{array}$ \\
\hline S07 & $\begin{array}{l}\text { Irmão: } 21 \text { anos } \\
\text { Irmão: } 19 \text { anos }\end{array}$ & $\begin{array}{l}\text { Irmão: Administração } \\
\text { Irmão: Engenharia }\end{array}$ \\
\hline S08 & Irmã: 18 anos & Irmã: Colegial (supletivo) \\
\hline S09 & Irmão: 20 anos & Irmão: Comunicação/Publicidade \\
\hline S10 & Irmão: 21 anos & Irmão: Medicina \\
\hline S11 & Irmão: 16 anos & Irmão: $2^{\circ}$. Colegial \\
\hline S12 & $\begin{array}{l}\text { Irmão: } 23 \text { anos } \\
\text { Irmão: } 22 \text { anos } \\
\text { Irmão: } 18 \text { anos } \\
\text { Irmão: } 15 \text { anos } \\
\text { Irmã: } 9 \text { anos }\end{array}$ & $\begin{array}{l}\text { Irmão: formado em Esportes } \\
\text { Irmão: Direito } \\
\text { Irmão: Cursinho } \\
\text { Irmão: } 1^{\circ} \text {. Colegial } \\
\text { Irmã: } 3^{\text {a }} \text {. Série do } 1^{\circ} \text {. grau }\end{array}$ \\
\hline S13 & $\begin{array}{l}\text { Irmão: } 30 \text { anos } \\
\text { Irmão: } 28 \text { anos } \\
\text { Irmão: } 27 \text { anos } \\
\text { Irmão: } 24 \text { anos }\end{array}$ & $\begin{array}{l}\text { Irmão: Engenheiro Químico } \\
\text { Irmão: Engenheiro Mecatrônica } \\
\text { Irmão: Engenheiro Agrônomo } \\
\text { Irmão: Engenheiro Civil }\end{array}$ \\
\hline S14 & Irmão: 15 anos & Irmão: Colegial \\
\hline S15 & Irmão: 12 anos & Irmão: $6^{\mathrm{a}}$. Série do $1^{\circ}$. grau \\
\hline S16 & Irmã: 22 anos & Irmã: Administração \\
\hline S17 & Irmão: 25 anos & Irmão: trabalha no Banco do Brasil \\
\hline S18 & Irmã: 26 anos & Irmã: Psicologia \\
\hline
\end{tabular}




\begin{tabular}{|c|c|c|}
\hline Alunos & Irmãos: idade & Irmãos: o que fazem \\
\hline S19 & $\begin{array}{l}\text { Irmã: } 28 \text { anos } \\
\text { Irmã: } 19 \text { anos }\end{array}$ & $\begin{array}{l}\text { Irmã: Funcionária Pública (é uma } \\
\text { prima que foi criada pelos seus pais) } \\
\text { Irmã: Farmácia }\end{array}$ \\
\hline S20 & Irmã: 23 anos & Irmã: Jornalismo \\
\hline S21 & $\begin{array}{l}\text { Irmão: } 17 \text { anos } \\
\text { Irmã: } 15 \text { anos }\end{array}$ & $\begin{array}{l}\text { Irmão: } 3^{\circ} \text {. Colegial } \\
\text { Irmã: } 1^{\circ} \text {. Colegial }\end{array}$ \\
\hline
\end{tabular}




\begin{tabular}{|c|c|c|}
\hline Alunos & $\begin{array}{l}\text { O que seus pais queriam que você } \\
\text { seguisse profissionalmente? }\end{array}$ & $\begin{array}{l}\text { Como seus pais reagiram quanto à } \\
\text { escolha de sua profissão? }\end{array}$ \\
\hline S01 & $\begin{array}{l}\text { Os meus pais queriam que eu fizesse o } \\
\text { que eu quisesse. }\end{array}$ & $\begin{array}{l}\text { Ficaram felizes, acho que mais felizes } \\
\text { do que eu. }\end{array}$ \\
\hline S02 & $\begin{array}{l}\text { Sempre pedi opiniões do que eles } \\
\text { achavam; meu pai falou que qualquer } \\
\text { coisa de esporte e minha mãe, } \\
\text { Psicologia ou Relações Públicas. }\end{array}$ & $\begin{array}{l}\text { Ninguém falou ou comentou nada; } \\
\text { preocupam-se em saber se eu estou } \\
\text { gostando e feliz com o curso. }\end{array}$ \\
\hline S03 & $\begin{array}{l}\text { Meus pais nunca desejaram que eu } \\
\text { seguisse qualquer profissão que eles } \\
\text { quisessem. }\end{array}$ & $\begin{array}{l}\text { Meu pai reagiu de modo normal e } \\
\text { minha mãe gostou mais, apareceu } \\
\text { mais a felicidade dela. }\end{array}$ \\
\hline S04 & $\begin{array}{l}\text { Quando eu era pequena eu queria ser } \\
\text { arquiteta, mas meus pais nunca me } \\
\text { forçaram a nada. }\end{array}$ & $\begin{array}{l}\text { Reagiram de modo normal; minha mãe } \\
\text { achou bom, me dá muita força, bem } \\
\text { como o meu pai. }\end{array}$ \\
\hline S05 & $\begin{array}{l}\text { Meu pai nunca falou nada e minha } \\
\text { mãe quando falei que queria fazer } \\
\text { arquitetura, me disse que sabia que } \\
\text { não era isso que eu gostava; quando } \\
\text { optei por Psicologia ela me deu muito } \\
\text { apoio. }\end{array}$ & Ambos me deram apoio. \\
\hline S06 & $\begin{array}{l}\text { Meus pais nunca se meteram em quase } \\
\text { nada da minha vida e minha mãe me } \\
\text { apoiou; é ela quem paga minha } \\
\text { faculdade. }\end{array}$ & $\begin{array}{l}\text { Minha mãe ficou contente e meu pai } \\
\text { foi indiferente, ele sempre foi meio } \\
\text { indiferente com as coisas. }\end{array}$ \\
\hline \begin{tabular}{|l|} 
S07 \\
\end{tabular} & $\begin{array}{l}\text { Nunca falaram o que eu devia seguir; } \\
\text { meu pai disse que era difícil arranjar } \\
\text { trabalho em Psicologia, mas não se } \\
\text { opôs; minha mãe sempre me apoiou, } \\
\text { acha que tem a minha cara, deu a idéia } \\
\text { de eu fazer nutrição. }\end{array}$ & $\begin{array}{l}\text { Desejaram parabéns e para eu levar a } \\
\text { sério. }\end{array}$ \\
\hline
\end{tabular}




\begin{tabular}{|c|c|c|}
\hline Alunos & $\begin{array}{l}\text { O que seus pais queriam que você } \\
\text { seguisse profissionalmente? }\end{array}$ & $\begin{array}{l}\text { Como seus pais reagiram quanto à } \\
\text { escolha de sua profissão? }\end{array}$ \\
\hline S08 & $\begin{array}{l}\text { Meu pai tentou me orientar para uma } \\
\text { profissão; quando eu quis fazer } \\
\text { Psicologia, ele falou que não tinha } \\
\text { futuro e que era para eu fazer } \\
\text { Economia ou Direito; minha mãe não } \\
\text { falou nada. }\end{array}$ & $\begin{array}{l}\text { Quando eu entrei em Psicologia foi } \\
\text { uma realização; meus pais se } \\
\text { emocionaram quando souberam. }\end{array}$ \\
\hline S09 & $\begin{array}{l}\text { Meus pais não me direcionaram, } \\
\text { deixaram que eu escolhesse. Qdo fui } \\
\text { fazer Administração, meu pai me } \\
\text { cobrava muito, mas depois não; minha } \\
\text { mãe me cobrava; eles não se } \\
\text { empolgaram quando entrei em } \\
\text { Administração. }\end{array}$ & Reagiram bem. \\
\hline S10 & $\begin{array}{l}\text { Minha mãe nunca se manifestou } \\
\text { muito, meu pai queria que eu fizesse } \\
\text { algo que desse dinheiro: Medicina, } \\
\text { Administração,Engenharia,Advocacia, } \\
\text { etc. }\end{array}$ & $\begin{array}{l}\text { Minha mãe reagiu normal, meu pai } \\
\text { veio com a conversa de que Psicologia } \\
\text { não ia dar dinheiro e tentou me } \\
\text { convencer; não tinha mais o que fazer, } \\
\text { teve que aceitar. }\end{array}$ \\
\hline S11 & $\begin{array}{l}\text { Meus pais não queriam que eu } \\
\text { seguisse uma profissão. }\end{array}$ & $\begin{array}{l}\text { Não fez tanta diferença, não queriam } \\
\text { que eu fosse filósofa, gostaram que eu } \\
\text { entrei em Psicologia e não opinaram } \\
\text { tanto. }\end{array}$ \\
\hline S12 & $\begin{array}{l}\text { Meu pai achava que eu tinha jeito para } \\
\text { Psicologia, mas falava pouco; minha } \\
\text { mãe falava mais para eu fazer } \\
\text { Psicologia; falaram para eu pensar } \\
\text { bem no que eu ia escolher, porque me } \\
\text { dariam o maior apoio. }\end{array}$ & Ficaram super felizes. \\
\hline S13 & $\begin{array}{l}\text { Meus pais nunca me cobraram, bem } \\
\text { como de nenhum dos filhos. }\end{array}$ & $\begin{array}{l}\text { Minha mãe gostou e eles se animaram } \\
\text { e torceram por isso. }\end{array}$ \\
\hline
\end{tabular}




\begin{tabular}{|c|c|c|}
\hline Alunos & $\begin{array}{l}\text { O que seus pais queriam que você } \\
\text { seguisse profissionalmente? }\end{array}$ & $\begin{array}{l}\text { Como seus pais reagiram quanto à } \\
\text { escolha de sua profissão? }\end{array}$ \\
\hline S14 & $\begin{array}{l}\text { Não disseram nada, minha mãe achava } \\
\text { que eu tinha dom para arquitetura. }\end{array}$ & $\begin{array}{l}\text { Ficaram felizes; morar sozinho aqui é } \\
\text { um sonho do meu pai que se } \\
\text { concretizou, minha mãe está } \\
\text { orgulhosíssima. }\end{array}$ \\
\hline S15 & $\begin{array}{l}\text { Nunca falaram nada, meu pai tirava } \\
\text { sarro para que eu fizesse Química, } \\
\text { mas dizia para eu fazer o que eu } \\
\text { quisesse. }\end{array}$ & $\begin{array}{l}\text { Minha mãe achou que eu iria me dar } \\
\text { bem, meu pai também, tirava sarro } \\
\text { dizendo que eu iria analisar todo } \\
\text { mundo. }\end{array}$ \\
\hline S16 & $\begin{array}{l}\text { Nunca falaram nada, tiveram um } \\
\text { pouco de medo pelo campo da } \\
\text { Psicologia, falaram para eu "ficar } \\
\text { esperta". }\end{array}$ & Ficaram felizes. \\
\hline S17 & Nunca deram opinião a respeito. & $\begin{array}{l}\text { Queriam que eu estudasse na USP, } \\
\text { independente da carreira. }\end{array}$ \\
\hline S18 & $\begin{array}{l}\text { Meu pai dizia que teria orgulho se } \\
\text { algum dos filhos seguisse Medicina; } \\
\text { minha mãe não falava nada. }\end{array}$ & $\begin{array}{l}\text { Ficaram felizes por eu ter entrado na } \\
\text { USP, tentei } 3 \text { anos seguidos. }\end{array}$ \\
\hline S19 & $\begin{array}{l}\text { Nunca influenciaram diretamente; } \\
\text { achavam legal Medicina. }\end{array}$ & $\begin{array}{l}\text { Minha mãe percebia que eu estava } \\
\text { seguro do que eu queria fazer já no } 2^{\circ} \text {. } \\
\text { Colegial; ela ficou contente, mas não } \\
\text { houve grandes euforias. }\end{array}$ \\
\hline S20 & $\begin{array}{l}\text { Meu pai tem preocupação com } \\
\text { dinheiro, dava sugestões de coisas que } \\
\text { eu poderia gostar e ganhar dinheiro ao } \\
\text { mesmo tempo; minha mãe sempre } \\
\text { falou para eu fazer aquilo que eu } \\
\text { tivesse paixão. }\end{array}$ & Felizes e emocionados. \\
\hline
\end{tabular}




\begin{tabular}{|c|c|c|}
\hline Alunos & $\begin{array}{l}\text { O que seus pais queriam que você } \\
\text { seguisse profissionalmente? }\end{array}$ & $\begin{array}{l}\text { Como seus pais reagiram quanto à } \\
\text { escolha de sua profissão? }\end{array}$ \\
\hline S21 & $\begin{array}{l}\text { Meu pai falava que tal profissão era } \\
\text { boa, mas que Física, Medicina e } \\
\text { Psicologia não; minha mãe não falou } \\
\text { nada, que eu escolhesse algo que eu } \\
\text { gostasse e desse dinheiro. }\end{array}$ & $\begin{array}{l}\text { Se fosse pela } 1^{\text {a }} \text {. Escolha meu pai não } \\
\text { teria gostado muito, sendo que } \\
\text { Filosofia até que gostaram; ficaram } \\
\text { assustados quando eu iniciei Filosofia. }\end{array}$ \\
\hline
\end{tabular}




\section{ANEXO B}

RELATO DAS RESPOSTAS DA PRANCHA N ${ }^{\circ}$. 1 DO TAT DOS ALUNOS DO $1^{\circ} \mathrm{E}^{\circ}$ ANOS DO CURSO DE PSICOLOGIA 
RELATO DAS RESPOSTAS DA PRANCHA N ${ }^{\circ} .1$ DO TAT DOS

ALUNOS DO $1^{\circ} \mathrm{E} 2^{\circ}$ ANOS DO CURSO DE PSICOLOGIA

\begin{tabular}{|c|c|c|}
\hline Alunos & Caracterização & Respostas da Prancha $\mathrm{n}^{\circ} .1$ do TAT \\
\hline S01 & $\begin{array}{l}\text { Aluna USP; } 1^{\circ} \text {. } \\
\text { ano; } 20 \text { anos; } \\
\text { solteira }\end{array}$ & $\begin{array}{l}\text { TR - 8” } \\
\text { Pode ser grande? Menino entediado, vai ter uma aula de } \\
\text { violão, que não quer fazer, não quer se aplicar, mas tem } \\
\text { forças que o obrigam a fazer essa aula. Por detrás dessa } \\
\text { pressão tem parentes que lhe deram o violão, um } \\
\text { instrumento que esperam que ele possa seguir essa } \\
\text { profissão e gostariam que ele espelhasse o que alguém da } \\
\text { família é; no final ele vai pegar o instrumento, vai tocar, } \\
\text { mas não porque seja a opção dele, mas porque tem que } \\
\text { corresponder a tais expectativas. Fim. } \\
\text { Inquérito: } \\
\text { Por que ele está entediado? } \\
\text { Pelas expressões faciais dele, pela forma que ele está, onde } \\
\text { não tem o menor interesse. } \\
\text { Por que não quer o violão? } \\
\text { Eu tirei isso por conta da cara dele, se ele quisesse dá para } \\
\text { perceber um distanciamento entre ele e o instrumento. } \\
\text { O que ele quer? } \\
\text { Brincar, sair de casa, de repente tocar um outro instrumento } \\
\text { que não seja esse, pode até ser outro, viajar, etc. } \\
\text { Como se sente? } \\
\text { Não se sente bem, mas provavelmente se sente menos mal } \\
\text { fazendo aquilo que não gosta, apesar das pressões pesarem } \\
\text { muito mais do que os interesses próprios. } \\
\text { Oítulo para a estória: não deu } \\
\text { Acho que espera não precisar mais fazer aquilo que ele não } \\
\text { gues.....pêra aí....mas fazendo aquilo que acabe }\end{array}$ \\
\hline
\end{tabular}




\begin{tabular}{|c|c|c|}
\hline Alunos & Caracterização & Respostas da Prancha $\mathrm{n}^{\circ} .1$ do TAT \\
\hline S02 & $\begin{array}{l}\text { Aluna FMU; } 2^{\circ} \text {. } \\
\text { Ano; } 19 \text { anos; } \\
\text { solteira }\end{array}$ & $\begin{array}{l}\text { TR - 15" } \\
\text { Vejo mais a minha infância, uma criança....uma criança } \\
\text { estudando, concentrada em alguma coisa. } \\
\text { Não consigo ver direito o que é isso....um instrumento de } \\
\text { música, mas não sei identificar qual é. Todo mundo precisa } \\
\text { de um tempo sozinho para se concentrar; quando eu estudo } \\
\text { preciso disso, de nenhum barulho. Tô vendo uma criança } \\
\text { solitária; quando eu estudo me disperso muito fácil das } \\
\text { coisas, o tempo que cada um precisa das coisas. } \\
\text { Título para a estória: não deu }\end{array}$ \\
\hline S03 & $\begin{array}{l}\text { Aluna FMU; } 2^{\circ} \\
\text { ano; } 20 \text { anos; } \\
\text { solteira }\end{array}$ & $\begin{array}{l}\text { TR -4" } \\
\text { O menino chamado Lucas, tem } 10 \text { anos, está na escola } \\
\text { esperando a mãe vir buscar ela...ele tá muito pensativo } \\
\text { agora, não agüenta mais esperar a mãe que está } \\
\text { atrasada...do lado dele têm uns colegas também esperando } \\
\text { os pais chegarem e cada um pode escolher uma coisa para } \\
\text { se distrair, para esperar o tempo passar. Ele tem uma irmã } \\
\text { de } 3 \text { anos. Cuida bem dela e quando a mãe dele chegar a } \\
\text { irmã vai estar junto e ele pensando que tem saudade da irmã } \\
\text { e preocupado que a mãe tá demorando. Procurando uma } \\
\text { professora para perguntar da mãe dele e os professores } \\
\text { estão na secretaria e não têm como avisar ninguém. } \\
\text { Inquérito: } \\
\text { Por que está preocupado com o atraso da mãe? } \\
\text { Porque a mãe nunca atrasa e hoje ela atrasou; ficou } \\
\text { preocupado com a irmã dele e de estar doente, de ter se } \\
\text { machucado em algum lugar; ele tava impaciente, mas nem } \\
\text { tanto; tava mais ou menos. } \\
\text { Título para a estória: "não sei” }\end{array}$ \\
\hline
\end{tabular}




\begin{tabular}{|c|c|c|}
\hline Alunos & Caracterização & Respostas da Prancha $\mathrm{n}^{\circ} .1$ do TAT \\
\hline S04 & $\begin{array}{l}\text { Aluna FMU; } 2^{\circ} \text {. } \\
\text { ano; } 21 \text { anos; } \\
\text { solteira }\end{array}$ & $\begin{array}{l}\text { TR - 7" } \\
\text { Eu vejo.....um menino meio concentrado vendo um } \\
\text { instrumento musical, violino, concentrado, ver o que ele faz } \\
\text { com esse violino, se pega, toca, só observa, está sobre um } \\
\text { pano branco, escuro atrás, parece que a luz está sobre ele, } \\
\text { meio que luz e sombra; dá para perceber bastante que tem } \\
\text { um instrumento musical e um menino observando. Tem um } \\
\text { rosto muito puro, coisa de criança, inocência. } \\
\text { Inquérito: } \\
\text { Por que ele está concentrado? } \\
\text { Acho que o pensamento, quando você pensa, passa tanta } \\
\text { coisa pela cabeça, pode virar um músico, seguir carreira, ou } \\
\text { nada disso; acho que o pensamento faz a gente ficar em } \\
\text { dúvida; quando você pensa, você viaja um pouco, sua } \\
\text { cabeça viaja rápido e nem sempre dá par acompanhar o } \\
\text { raciocínio. Parece ficar angustiado de realmente não saber o } \\
\text { que fazer e está em dúvida mesmo, "nem sei o que vou } \\
\text { fazer com isso!?, se é o que eu gosto, se é o que eu } \\
\text { gosto...”, mas acho que é o que ele gosta mesmo, porque } \\
\text { senão não estaria tão atento, está dentro dele. } \\
\text { Título para a estória: "O menino pensativo" }\end{array}$ \\
\hline
\end{tabular}




\begin{tabular}{|c|c|c|}
\hline Alunos & Caracterização & Respostas da Prancha $\mathrm{n}^{\circ} .1$ do TAT \\
\hline S05 & $\begin{array}{l}\text { Aluna FMU; } 2^{\circ} \text {. } \\
\text { ano; } 20 \text { anos; } \\
\text { solteira }\end{array}$ & $\begin{array}{l}\text { TR - 4" } \\
\text { Um menino que está olhando para o violino, parece estar } \\
\text { cansado, estudando um pouco, o que está fazendo com isso, } \\
\text { o que está fazendo com o violino, estudando, resolveu parar } \\
\text { de tocar para refletir o por quê de tocar violino, parece um } \\
\text { pouco cansado. Acho que é essa a dúvida dele, é por isso } \\
\text { que ele está olhando pra o violino; olhando de uma forma } \\
\text { que é exatamente isso que ele quer saber, por quê? } \\
\text { Inquérito: } \\
\text { Por que ele está cansado? } \\
\text { Porque ele está segurando a cabeça frente ao violino; se ele } \\
\text { gostasse realmente de tocar violino, a foto mudaria; ele tem } \\
\text { dúvidas e parou para refletir sobre isso; mais uma forma de } \\
\text { reflexão de “qual minha posição diante disso". } \\
\text { Título da estória: Reflexão }\end{array}$ \\
\hline S06 & $\begin{array}{l}\text { Aluna } \quad \text { São } \\
\text { Marcos; } \quad 2^{\circ} \text {.ano; } \\
22 \text { anos; solteira }\end{array}$ & $\begin{array}{l}\text { TR - 10" } \\
\text { Certa vez um garotinho se sentindo muito só, resolveu } \\
\text { refletir sobre a vida dele, do por quê da existência do ser } \\
\text { humano....conforme ele foi entrando em contato, foi } \\
\text { ficando triste por perceber a profundidade da questão, } \\
\text { sentiu melancolia, tristeza, um vazio muito grande, não só } \\
\text { por estar com ele mesmo, mas se dar conta de como os } \\
\text { seres humanos são indivíduos egocêntricos. } \\
\text { Inquérito: } \\
\text { Por que ele está melancólico? } \\
\text { Acho que tem a ver com o que estou vivendo no momento, } \\
\text { foi projeção; estou passando por isso, melancolia, tristeza e } \\
\text { ficou pensando na vida } \\
\text { Título da estória: "O garoto melancólico" }\end{array}$ \\
\hline
\end{tabular}




\begin{tabular}{|c|c|c|}
\hline Alunos & Caracterização & Respostas da Prancha $\mathrm{n}^{\circ} .1$ do TAT \\
\hline \begin{tabular}{|l|l|} 
S07 \\
\end{tabular} & $\begin{array}{l}\text { Aluna } \quad \text { São } \\
\text { Marcos; } 1^{\circ} \text {. Ano; } \\
17 \text { anos; solteira }\end{array}$ & $\begin{array}{l}\text { TR - 11" } \\
\text { O menino está de castigo, porque brigou com a irmã mais } \\
\text { velha e a mãe o colocou para estudar, considerando que isso } \\
\text { (aponta para o violino) poderia ser uma apostila, ou um } \\
\text { caderno, não sei direito, não dá para ver. } \\
\text { Inquérito: } \\
\text { Por que ele brigou com a irmã? } \\
\text { Brigaram pelo mesmo brinquedo que eles queriam e o que } \\
\text { o deixou mais triste é que a mãe sempre defende a irmã; } \\
\text { ficou nervoso, sentindo-se injustiçado, porque a irmã dele } \\
\text { também deveria estar de castigo. } \\
\text { Título da estória: “A briga", não me vem nada melhor na } \\
\text { cabeça agora. }\end{array}$ \\
\hline S08 & $\begin{array}{l}\text { Aluna PUC/SP; } \\
2^{\circ} \text {. Ano; } 19 \text { anos; } \\
\text { solteira }\end{array}$ & $\begin{array}{l}\text { TR - 5" } \\
\text { Um menino com um violino, parecendo meio tenso, } \\
\text { provavelmente para ele tocar algo e ele não consegue, ele } \\
\text { está bastante preocupado. } \\
\text { Inquérito: } \\
\text { O que o preocupa? } \\
\text { Pensaria que provavelmente estão exigindo desse } \\
\text { menininho dele tocar e talvez os pais exigem algo dele, uma } \\
\text { pressão pra tocar melhor, eu acho que vem daí. } \\
\text { Como ele se sente? } \\
\text { Acho que angustiado, porque ninguém pergunta para ele se } \\
\text { ele quer isso, ou nada de profissionalismo, essas coisas; ele } \\
\text { pensa "eu gosto de tocar, acho que toco bem, mas não } \\
\text { quero me preocupar com isso agora, acho que tenho muita } \\
\text { coisa para viver". } \\
\text { Título da estória: Algo como a angústia que ele está } \\
\text { passando pelas mudanças na vida dele. }\end{array}$ \\
\hline
\end{tabular}




\begin{tabular}{|c|c|c|}
\hline Alunos & Caracterização & Respostas da Prancha $\mathrm{n}^{\circ} .1$ do TAT \\
\hline S09 & $\begin{array}{l}\text { Aluno USP; } 2^{\circ} \text {. } \\
\text { Ano; } 22 \text { anos; } \\
\text { solteiro }\end{array}$ & $\begin{array}{l}\text { TR - 3" } \\
\text { Era uma vez um menino que queria muito ser músico, não } \\
\text { conseguia estudar à vontade, muito barulho na casa, os } \\
\text { irmãos atrapalhavam. A cara dele não sei se muito afim do } \\
\text { violino, semblante preocupado, meio travado, ambiente } \\
\text { meio escuro também. Ele está incomodado; ele tem } \\
\text { interesse pelo instrumento, queria estar mais à vontade, mas } \\
\text { não consegue; está num lugar onde não o possibilita muito } \\
\text { isso, devido a barulheira. } \\
\text { Título da estória: "Desencontro". }\end{array}$ \\
\hline S10 & $\begin{array}{l}\text { Aluno USP; } 1^{\circ} . \\
\text { Ano; } 19 \text { anos; } \\
\text { solteiro }\end{array}$ & $\begin{array}{l}\text { TR - 24" } \\
\text { O que é isso? (aponta para o violino) Tenho uma amiga que } \\
\text { toca violino, que começou a tocar e eu estava na casa dela e } \\
\text { ela disse que não estava conseguindo tocar, não conseguia } \\
\text { achar a nota, colocava uma fita crepe para achar o tom. } \\
\text { Quer que conte outra? Eu, minha namorada e meu irmão } \\
\text { fomos num concerto em Campos do Jordão e acho que era } \\
\text { orquestra de sopro, não sei, era outra; começamos a agitar e } \\
\text { gritar "bis, bis" e ficamos berrando e tocaram o que o } \\
\text { pessoal pediu. Foi engraçado, foi legal; lembrei porque na } \\
\text { orquestra tinha bastante violino, por isso não era de sopro. } \\
\text { Títulos das estórias: "Problemas com violinos?" e "Aquela } \\
\text { do bis". }\end{array}$ \\
\hline
\end{tabular}




\begin{tabular}{|c|c|c|}
\hline Alunos & Caracterização & Respostas da Prancha $n^{\circ} .1$ do TAT \\
\hline S11 & $\begin{array}{l}\text { Aluna USP; } 2^{\circ} . \\
\text { Ano; } 22 \text { Anos; } \\
\text { solteira }\end{array}$ & $\begin{array}{l}\text { TR - 14" } \\
\text { O que é isso? (aponta para o violino) Não consigo } \\
\text { identificar o que é isso, parece muitas coisas ao mesmo } \\
\text { tempo. Era uma vez o Joaquim que estava vendo uma aula } \\
\text { de Orientação Educacional e não estava interessado na aula, } \\
\text { ao mesmo tempo que estava pensando como essa aula era } \\
\text { inútil. Várias imagens vieram à sua cabeça que são esse } \\
\text { desenho aqui, que eu não sei o que são que está associando. } \\
\text { Penso numa arma, numa camisa, numa armadilha para } \\
\text { ratos; tem sono volta a prestar atenção à aula e concentrado } \\
\text { nele e nas imagens. A aula acaba e ela volta ao mundo da } \\
\text { matéria. } \\
\text { Inquérito: } \\
\text { Como ele se sente ao não identificar o que está vendo? } \\
\text { Está confuso e pensando em várias coisas, } \\
\text { inconscientemente; está com sono e está vendo isso como } \\
\text { um segundo pensamento. Título da Estória: não deu }\end{array}$ \\
\hline
\end{tabular}




\begin{tabular}{|c|c|c|}
\hline Alunos & Caracterização & Respostas da Prancha $\mathrm{n}^{\circ} .1$ do TAT \\
\hline S12 & $\begin{array}{l}\text { Aluna USP; } 2^{\circ} \text {. } \\
\text { Ano; } 20 \text { anos; } \\
\text { solteira }\end{array}$ & $\begin{array}{l}\text { TR - 30" } \\
\text { Era uma vez um menininho, filho único, sentia-se sozinho e } \\
\text { tinha um problema específico, tinha fotofobia e não } \\
\text { conseguia enxergar; era o mais velho da classe e os amigos } \\
\text { não gostavam dele; tinha } 6 \text { anos de idade e gostava de } \\
\text { música, mas não acreditava que era limitado, tinha } \\
\text { capacidade e começou a aprender música e foi se } \\
\text { envolvendo mais com a sociedade e foi feliz para sempre. } \\
\text { Inquérito: } \\
\text { Como ele se sentia com o problema? } \\
\text { Não tão mal, porque a mãe lhe fazia sentir mais } \\
\text { confortável, tinha colo, carinho, percebia-se diferente, mas } \\
\text { não o afetava; não podia estudar em escola normal; com o } \\
\text { problema visual sentia-se diferente, mas não inferior. } \\
\text { Como os pais lidavam com a deficiência dele? } \\
\text { Mãe queria um filho, teve dificuldade para engravidar e } \\
\text { relutou em aceitar, não quis ver como um problema, mas } \\
\text { como uma limitação; o pai tinha mais expectativa e a mãe } \\
\text { com o grande amor, tinha mais envolvimento; mãe lidava } \\
\text { melhor com ele, do que com sua deficiência; ele era muito } \\
\text { inteligente. } \\
\text { Título da estória: “O menino e o violino". }\end{array}$ \\
\hline
\end{tabular}




\begin{tabular}{|c|c|c|}
\hline Alunos & Caracterização & Respostas da Prancha $n^{\circ} .1$ do TAT \\
\hline S13 & $\begin{array}{l}\text { Aluna USP; } 1^{\circ} \text {. } \\
\text { Ano; } 26 \text { anos; } \\
\text { casada }\end{array}$ & $\begin{array}{l}\text { TR - 16" } \\
\text { Parece uma criança com desânimo, olhando algo que queria } \\
\text { fazer e por algum motivo está proibida. Passa a impressão } \\
\text { de estar cansada com um monte de lição teórica para fazer e } \\
\text { fazer algo com música que ela gosta; ela não pode. Não está } \\
\text { conseguindo tirar prazer do violino como gostaria de tirar. } \\
\text { Inquérito: } \\
\text { Por que essa criança está desanimada? } \\
\text { Por causa dessa folha enorme que está embaixo do violino, } \\
\text { tarefa enorme que tem que cumprir e é o que se espera, que } \\
\text { é necessário, onde acaba tirando esse prazer; sente-se } \\
\text { desanimada. } \\
\text { Título da estória: "A música que eu quero tocar e não } \\
\text { posso" }\end{array}$ \\
\hline S14 & $\begin{array}{l}\text { Aluno USP; } 1^{\circ} \text {. } \\
\text { Ano; } 18 \text { anos; } \\
\text { solteiro }\end{array}$ & $\begin{array}{l}\text { TR - 13" } \\
\text { Um menino sempre quis aprender a tocar violino, } \\
\text { fascinação; num belo dia ganhou um violino, como } \\
\text { admiração, mas não prática, tá olhando e na dúvida se ele } \\
\text { toca ou não, com a cara de monólogo interior, parecendo } \\
\text { estar se sentindo desafiado a tocar. } \\
\text { Inquérito: } \\
\text { Como ele está se sentindo? } \\
\text { Talvez ele esteja fascinado, mas por ser muito importante, } \\
\text { uma coisa muito grande, está com medo de não conseguir, } \\
\text { medo do fracasso. Pode estar olhando para o violino, } \\
\text { olhando e lembrando do dono do violino com saudade; cara } \\
\text { de lembrança. } \\
\text { Título da estória: "Saudade, Dúvida" }\end{array}$ \\
\hline
\end{tabular}




\begin{tabular}{|c|c|c|}
\hline Alunos & Caracterização & Respostas da Prancha $\mathrm{n}^{\circ} .1$ do TAT \\
\hline S15 & $\begin{array}{l}\text { Aluna USP; } 2^{\circ} . \\
\text { Ano; } 18 \text { Anos; } \\
\text { solteira }\end{array}$ & $\begin{array}{l}\text { TR - 3" } \\
\text { Um menininho que aqui tem um cinto, é um cinto? Ele está } \\
\text { com algo na mão e parece estar concentrado, investigando } \\
\text { algo, tentando estudar num lugar escuro. Foi procurar algo } \\
\text { no escuro e ver esse objeto, tentando entender o que é esse } \\
\text { objeto. } \\
\text { Inquérito: } \\
\text { Com o que ele está na mão? } \\
\text { É um objeto curioso, porque não dá para entender direito o } \\
\text { que é e todo mundo quando não sabe o que é, fica curioso } \\
\text { para entender. Parece uma dobradiça aqui, um cinto; às } \\
\text { vezes parece um instrumento musical também. } \\
\text { O que lhe dá a impressão dele estar concentrado? } \\
\text { Pela carinha dele, parece estar meio angustiado, parece que } \\
\text { entrou aí procurando algo, tentando entender as coisas, } \\
\text { olhos baixos. } \\
\text { Título da estória: “O que é isso?" }\end{array}$ \\
\hline S16 & $\begin{array}{l}\text { Aluna USP; } 2^{\circ} . \\
\text { Ano; } 20 \text { Anos; } \\
\text { solteira }\end{array}$ & $\begin{array}{l}\text { TR - 3" } \\
\text { Parece um instrumento que parece um violão e que o } \\
\text { menino parece triste, parece quebrado e ele não sabe como } \\
\text { consertar. Pode já estar quebrado e ele não sabe como fazer, } \\
\text { apareceu o violão quebrado. Pensa: "Como eu vou fazer } \\
\text { para arrumar isso?" Acho que deveria pedir ajuda para } \\
\text { alguém, porque pela cara dele, ele não tem nem idéia. } \\
\text { Inquérito: } \\
\text { Ele vai conseguir consertar? } \\
\text { Ele vai conseguir consertar o violão sim, primeiro porque } \\
\text { parece que ele não está tão quebrado assim e segundo, pela } \\
\text { cara dele, parece que vai consertar, está pensativo e com } \\
\text { vontade. } \\
\text { Título da estória: “O menino e o violão" }\end{array}$ \\
\hline
\end{tabular}




\begin{tabular}{|c|c|c|}
\hline Alunos & Caracterização & Respostas da Prancha $\mathrm{n}^{\circ} .1$ do TAT \\
\hline S17 & $\begin{array}{l}\text { Aluna USP }-1^{\circ} \text {. } \\
\text { Ano; } 18 \text { Anos; } \\
\text { solteira }\end{array}$ & $\begin{array}{l}\text { TR - 5" } \\
\text { É um menino com violino? Puts eu sou ruim pra estória! } \\
\text { Acho que é um menino que toca violino, mas ele deve ter } \\
\text { quebrado o violino e é por isso que ele está triste, bem eu } \\
\text { acho que ele está triste. O pai deu uma bronca para piorar a } \\
\text { situação e agora ele está pensando o que pode fazer para } \\
\text { consertar. } \\
\text { Inquérito: } \\
\text { Como ele está se sentindo? } \\
\text { Ele deve ter derrubado o violino; ele deve ter sentido } \\
\text { meio....instrumento é uma coisa que é cara e deve ter ficado } \\
\text { preocupado por ter dado prejuízo. } \\
\text { E tem conserto esse violino? } \\
\text { Acho que tem conserto sim, deve ter um caminho, um jeito } \\
\text { para consertar, deve ter alguém que saiba consertar. } \\
\text { Título da estória: não sei. }\end{array}$ \\
\hline
\end{tabular}




\begin{tabular}{|c|c|c|}
\hline Alunos & Caracterização & Respostas da Prancha ${ }^{\circ} .1$ do TAT \\
\hline S18 & $\begin{array}{l}\text { Aluna USP; } 1^{\circ} . \\
\text { Ano; } 23 \text { Anos; } \\
\text { solteira }\end{array}$ & $\begin{array}{l}\text { TR - } 24 \text { “ } \\
\text { Parece um garoto entediado, ou triste, não sei, ele, não sei } \\
\text { se ele toca violino ou música do som do violino, lembra } \\
\text { alguém, pensei num pai que tocasse violino e não estivesse } \\
\text { mais presente. Parece ter alguns defeitos físicos, um olho } \\
\text { mais fechado que o outro, pois um eu vejo aberto e o outro } \\
\text { eu não vejo. Parece que o que está embaixo do violino é um } \\
\text { livro, mas não sei se é um livro; parece o rosto de uma } \\
\text { pessoa deficiente. } \\
\text { Inquérito: } \\
\text { Por que lembra o pai? } \\
\text { Talvez algo da minha experiência de vida, para mim as } \\
\text { pessoas que tocam instrumento, violino é instrumento de } \\
\text { homem e talvez seja isso, pode ser da minha experiência de } \\
\text { vida, sentir falta do meu pai como eu sinto. Sua fisionomia } \\
\text { é extremamente triste, não chego achar que é uma angústia, } \\
\text { mas olha para o violino como se estivesse sofrendo por } \\
\text { isso. } \\
\text { Por que parece ter um rosto de pessoa deficiente? } \\
\text { Sente-se inferior aos outros, ainda que não seja uma } \\
\text { inferioridade e sim uma diferença; se fosse eu me sentiria } \\
\text { inferior. } \\
\text { Título da estória: "Sofrimento ou ausência de alguém" }\end{array}$ \\
\hline
\end{tabular}




\begin{tabular}{|c|c|c|}
\hline Alunos & Caracterização & Respostas da Prancha $\mathrm{n}^{\circ} .1$ do TAT \\
\hline S19 & $\begin{array}{l}\text { Aluno USP; } 1^{\circ} \text {. } \\
\text { Ano; } 21 \text { Anos; } \\
\text { solteiro }\end{array}$ & $\begin{array}{l}\text { TR - 5" } \\
\text { Um garoto observa o violino e coloca nele uma forma de } \\
\text { tentar complementar uma deficiência no olho, então resolve } \\
\text { pela música sublimar essa deficiência. Devo divagar mais? } \\
\text { Inquérito: } \\
\text { O que é essa deficiência no olho? } \\
\text { Pode ser algo de nascença, ou machucou o olho, cara vem } \\
\text { deformada. } \\
\text { Como ele se sente? } \\
\text { Deve olhar para as pessoas que se não se sentir deprimido, } \\
\text { diferente, com menos qualidade do que outras pessoas, } \\
\text { então ele se pega na música para suprir as qualidades. } \\
\text { Como é para ele essa deficiência? } \\
\text { Deficiência....não pode ser sanada, parece......se pudesse } \\
\text { ser, não se apegaria a música; a música foi uma válvula de } \\
\text { escape; poderia se sentir triste, mas conseguia se completar } \\
\text { com a música. }\end{array}$ \\
\hline
\end{tabular}




\begin{tabular}{|c|c|c|}
\hline Alunos & Caracterização & Respostas da Prancha $n^{\circ} .1$ do TAT \\
\hline S20 & $\begin{array}{l}\text { Aluno USP; } 18 \\
\text { Anos; } 1^{\circ} \text {. Ano; } \\
\text { solteiro }\end{array}$ & $\begin{array}{l}\text { TR - 13" } \\
\text { É um menino pobre....difícil !!!! ele vem de uma família } \\
\text { muito simples, sem muita cultura, estava passando na rua, } \\
\text { porque vem da Europa e viu pessoas que tocavam violino e } \\
\text { pediam dinheiro e ficou atraído pelo violino e pela música. } \\
\text { Ele tem que trabalhar para ajudar os pais, estuda de manhã } \\
\text { e à tarde engraxa sapato. Não tinha muito tempo para ver o } \\
\text { homem tocar violino.....no outro dia passou no mesmo lugar } \\
\text { e viu novamente o homem tocar o violino e sonhando em } \\
\text { tocar violino,porque para ele talvez seja uma libertação; já } \\
\text { tem uma vida meia encaminhada e por ser pobre, está longe } \\
\text { de sua realidade e tocar é apaixonante. Não teve a } \\
\text { possibilidade, pode ser que um dia terá. } \\
\text { Inquérito: } \\
\text { Como ele se sente? } \\
\text { Sente-se triste,porque gostaria de ser mais dono de seu } \\
\text { destino, de suas possibilidades e injustiçado por tal } \\
\text { condição. Ele que quer, não pode e ao ver quem pode, esse } \\
\text { não quer. Sente uma certa angústia e não vê como abrir } \\
\text { uma brecha para isso; angústia, tristeza e injustiça, sonho da } \\
\text { vida dele, projeta no violino sua existência e sabe que não } \\
\text { pode. } \\
\text { Como vê seu futuro? } \\
\text { Talvez consiga tocar um dia, mas é difícil; não se sente } \\
\text { dono da capacidade de mudar. } \\
\text { sonho" }\end{array}$ \\
\hline
\end{tabular}




\begin{tabular}{|c|c|c|}
\hline Alunos & Caracterização & Respostas da Prancha $\mathrm{n}^{\circ} .1$ do TAT \\
\hline S21 & $\begin{array}{l}\text { Aluno USP; } 1^{\circ} . \\
\text { Ano; } 19 \text { Anos; } \\
\text { solteiro }\end{array}$ & $\begin{array}{l}\text { TR - 7” } \\
\text { Um garoto que ia ter que tocar, só que ele esqueceu e a mãe } \\
\text { dele também esqueceu do concerto que ia tocar pela } \\
\text { primeira vez e estava triste por causa disso. Isso aconteceu } \\
\text { por causa de uma estória de um menininho que eu estava } \\
\text { vendo por esses dias. } \\
\text { Inquérito: } \\
\text { Como foi para ele ter esquecido? } \\
\text { Perdendo uma oportunidade. } \\
\text { Como se sentiu? } \\
\text { Mal, pois era uma chance dele mostrar alguma coisa. } \\
\text { E a mãe como se sentiu? } \\
\text { Ela sentiu um pouco de culpa, mas não muita. } \\
\text { E ambos como ficaram? } \\
\text { Ele culpava mais a ele mesmo do que a mãe. } \\
\text { O que vai acontecer? } \\
\text { Ele vai continuar tocando e procurar não esquecer da } \\
\text { próxima vez. } \\
\text { Título da estória : “A música que não aconteceu.” }\end{array}$ \\
\hline
\end{tabular}


ANEXO C

TERMO DE CONSENTIMENTO 


\section{TERMO DE CONSENTIMENTO}

Dados de Identificação do sujeito da pesquisa:

01. Nome:

02. Sexo:

03. Data de Nascimento:

04. Idade:

05. Estado Civil:

06. Faculdade:

07. Ano:

08. Estudou em que colégio, público ou particular?

09. Endereço:

10. Telefone:

$\mathrm{Eu}$

através desse termo de consentimento, autorizo o psicólogo Antonio Geraldo de Abreu Filho - C.R.P. 06/6497, a utilizar os resultados da Prancha 1 do TAT - Teste de Apercepção Temática e da Entrevista Semidirigida, para único e exclusivo fím de Pesquisa Científica.

Meus dados pessoais não serão divulgados, sendo garantido assim, o sigilo de minha participação. 